\title{
norden
}

\section{GRÄNSHINDERRÅDETS ÅRSRAPPORT 2014}

MED KOMMENTARER FRÅN DE NORDISKA REGERINGARNA 
Gränshinderrådets årsrapport 2014 med kommentarer från de nordiska regeringarna

ISBN 978-92-893-3919-3 (PRINT)

ISBN 978-92-893-3920-9 (PDF)

http://dx.doi.org/10.6027/ANP2015-703

ANP 2015:703

(C) Nordiska ministerrådet 2015

Layout: Peter Daniel Olsen/Resonans Kommunikation

Foto: s. 6: Ragnar Th. Sigurdsson

s. 8, 9: Christiaan Dirksen

s. 17, 24, 29, 34, 47, 49, 52, 59, 65, 68, 73, 74, 81: Karin Beate Nøsterud

s. 51: Magnus Fröderberg

s. 87: Johannes Jansson

Beräkningarna är gjorda av Britt Andresen, chefsanalytiker, Øresundsinstituttet

Tryck: Rosendahls Schultz-Grafisk, Albertslund

Upplaga: 1500

Printed in Denmark

\section{Det nordiska samarbetet}

Det nordiska samarbetet är ett av världens mest omfattande regionala samarbeten. Det omfattar Danmark, Finland, Island, Norge och Sverige samt Färöarna, Grönland och Åland.

Det nordiska samarbetet är politiskt, ekonomiskt och kulturellt förankrat och är en viktig partner i europeiskt och internationellt samarbete. Den nordiska gemenskapen arbetar för ett starkt Norden i ett starkt Europa.

Det nordiska samarbetet vill styrka nordiska och regionala intressen och värderingar i en global omvärld. Gemensamma värderingar länderna emellan bidrar till att stärka Nordens ställning som en av världens mest innovativa och konkurrenskraftiga regioner.
Nordiska ministerrådet Ved Stranden 18 DK-1061 København K Telefon (+45) 33960200

www.norden.org 


\section{GRÄNSHINDERRÅDETS ÅRSRAPPORT 2014}

MED KOMMENTARER FRÅN DE NORDISKA REGERINGARNA

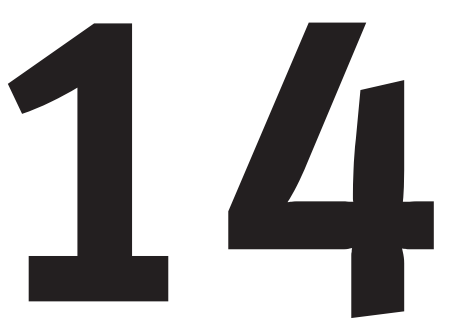





\section{De nordiska statsministrarnas deklaration med anledning av den nya strategin och handlingsplanen för avlägsnande av gränshinder i Norden. Den nya strategin och handlingsplanen behandlades vid Nordiska rådets 65:e session i oktober 2013.}

\section{Norden som föregångare för gränslöst samarbete i syfte att skapa jobb och tillväxt}

Vi, statsministrar från Danmark, Finland, Island, Norge och Sverige, lagmanden från Färöarna, landsstyreformanden i Grönland samt lantrådet på Åland, är eniga om att arbetet med att bekämpa gränshinder i syfte att skapa jobb och tillväxt i Norden, är en av det nordiska samarbetets viktigaste utmaningar. Detta gäller inte minst vårt gemensamma behov av att hjälpa unga människor in på arbetsmarknaden.

Genom att skapa optimala förutsättningar för individer och företag att verka över gränserna i Norden stärker vi regionens globala konkurrenskraft.

En starkt prioriterad insats är därför arbetet med att aktivt avlägsna gränshinder. Gränshinder kostar, hämmar utveckling och tillväxt och ger färre valmöjligheter för den enskilde.

Gränshinderforum, som tillsattes av de nordiska statsministrarna år 2007, har på ett värdefullt sätt arbetat för att minska gränshinder i Norden. För att ytterligare stärka och effektivisera gränshinderarbetet utvecklar vi nu organisationen till ett Gränshinderråd med en ny strategi- och handlingsplan, som kommer att träda i kraft den 1 januari 2014.

Detta innebär att:

Arbetet kommer att kopplas tätare till den politiska led- ningen i Nordiska ministerrådet genom att ordförandelandet i Nordiska ministerrådet också kommer att vara ordförande i Gränshinderrådet.

Nordiska ministerrådets generalsekreterare får en starkare roll i gränshinderarbetet för ministerrådet.

Gränshinderrådets nationella representanter får ett tydligt uppdrag att samarbeta med de aktörer som kan bidra till att få gränshinder lösta för individer och företag i Norden. Detta samarbete omfattar bl.a. ländernas departement och myndigheter, parlamentariker och de gränsregionala informationstjänsterna.

Den nya formen för nordiskt gränshindersarbete kommer att bidra till ett effektivare arbete för att riva gränshinder och öka rörligheten i Norden.

\section{För att uppnå detta bör vi ha som mål:}

- att verka för en öppen och välfungerande gemensam arbetsmarknad

- att skapa bästa möjliga förutsättningar för nordiska företag att verka över gränserna i Norden.

- att säkra, så långt det är möjligt, likartat genomförande av EU-rättslig lagstiftning i Norden genom en löpande dialog mellan de nordiska länderna.

- att verka för att länderna samråder, när så behövs, när nya eller ändrade lagar och regler införs i syfte att undvika att nya gränshinder uppstår. 
Lofintion

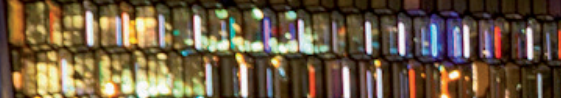

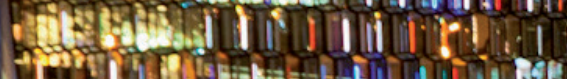

\section{int}

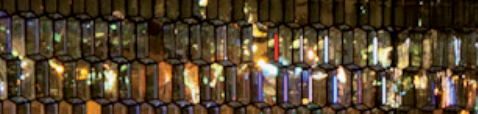

111\%1, s, $1, \ldots$

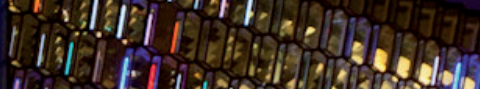

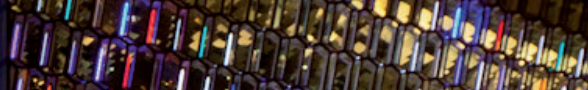

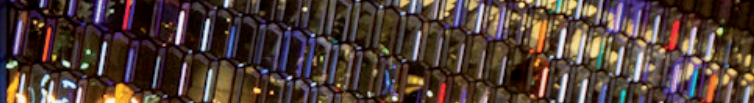

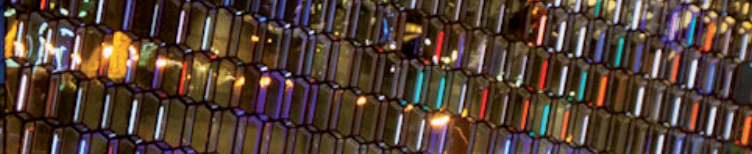

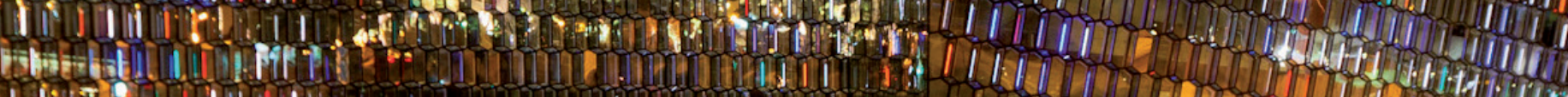

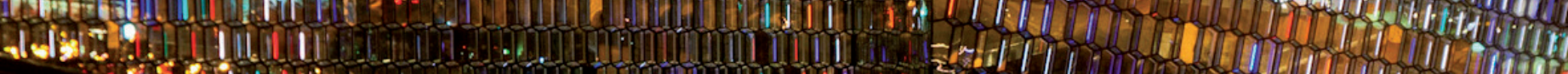
6. 4.

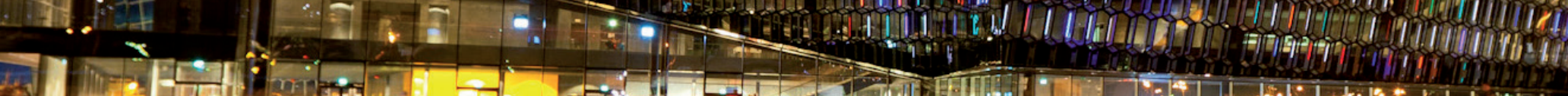

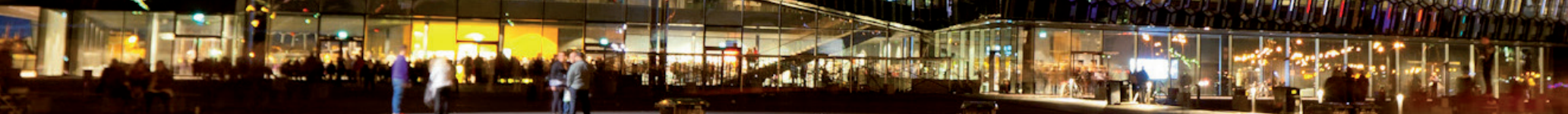

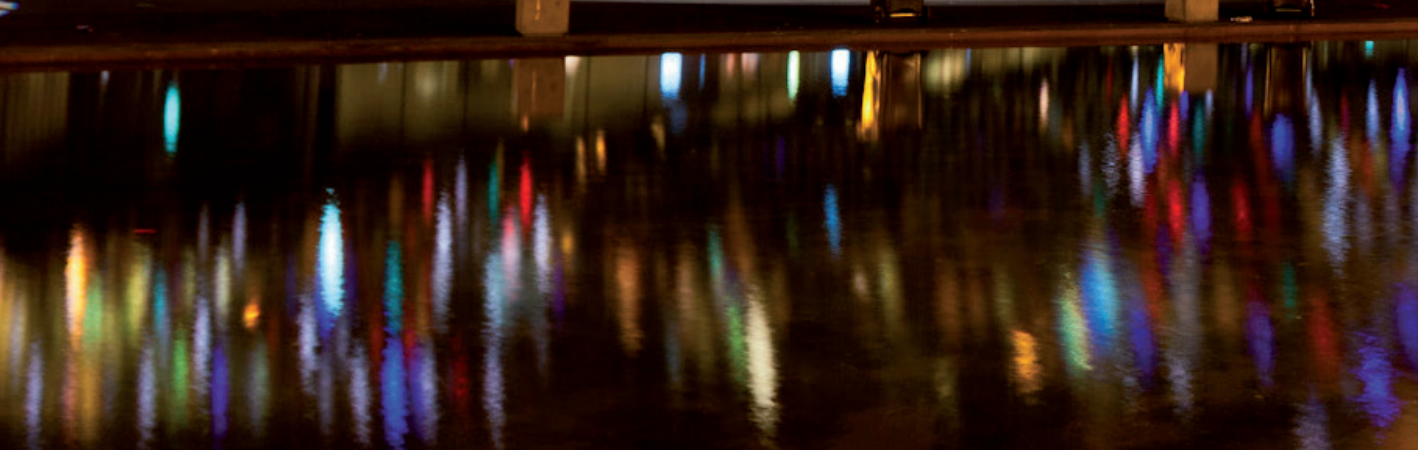




\section{Förord}

Du har i dina händer en summering av Gränshinderrådets arbete 2014. Materialet har sammanställts av Gränshinderrådet och förhoppningsvis ger denna översikt dig en inblick i det arbete vi gjort hittills.

På initiativ från de nordiska statsministrarna upprättade samarbetsministrarna det nya Gränshinderrådet och antog en handlingsplan för Gränshinderrådets organisering och arbete. Gränshinderrådet etablerades den 1 januari 2014 och inledde sin operativa verksamhet den 11 april 2014.

Gränshinderrådet består av åtta nationella medlemmar, en representant för Nordiska rådet samt generalsekreteraren i Nordiska ministerrådet. Ordförandeskapet i Gränshinderrådet följer ordförandeskapet i ministerrådet.

I år har Gränshinderrådet, med utgångs punkt i handlingsplanen, valt att prioritera organiseringen och implementeringen av den operativa verksamheten för Gränshinderrådet och det nordiska gränshinderarbetet. Det har tagit tid men har varit grundläggande för det fortsatta arbetet.

Handlingsplanen, som följer samarbetsministrarnas vision och målen för samarbete under de kommande åren gällande ett gränslöst Norden, har tre prioriterade insatsområden:

1. Avklara existerande gränshinder mellan de nordiska länderna.

2. Förebygga att nya gränshinder uppstår.

3. Öka och effektivisera informationsinsatserna.

Varje medlem i rådet prioriterar 3-5 gränshinder som ska följas upp tills de är lösta eller tills svar/skäl getts från berörda departement och myndigheter. Målet är att Gränshinderrådets insatser ska bidra till att eliminera 5-10 nordiska gränshinder per år.

Av Gränshinderrådets 29 prioriterade gränshinder har tre avklarats under året som gått, medan fyra är på god väg att lösas under 2015. Gränshinderrådets olika nätverk på regional, nationell och nordisk nivå har bidragit till att ytterligare 17 gränshinder blivit lösta i Norden under året som gått. En indikation på att Gränshinderrådet har lyckats bra med sin koordinerade roll och fokuserat på sin huvuduppgift, dvs. de prioriterade hindren, samtidigt som andra aktörer runtom i Norden har arbetat aktivt med att eliminera gränshinder.

Under 2014 har Gränshinderrådet tagit initiativ till att utveckla en strategi och handlingsplan för hur de nordiska länderna samt Färöarna, Grönland och Åland ska bidra till att förebygga uppkomsten av nya gränshinder vid regeländringar och införande av EU-direktiv. Gränshinderrådet har också försökt att förebygga uppkomsten av nya gränshinder i förbindelse med förslaget om att upphäva överenskommelsen om gemensam nordisk arbetsmarknad för vissa yrkesgrupper inom sjukvården och veterinärer (Arjeplogavtalet) som trädde i kraft 1994.

Gränshinderrådet har tagit initiativ till att utveckla och implementera en gemensam handlingsplan för den nordiska informationstjänsten Hallå Norden och de gränsregionala informationstjänsterna. Syftet med handlingsplanen är att effektivisera och understödja Gränshinderrådets arbete samt förbättra informationsinsatserna för privatpersoner och företag som vill röra sig över de nordiska nationsgränserna.

Jag hoppas att översikten kan bli ett inspel i den offentliga debatten om vikten av att eliminera och förebygga gränshinder i Norden.
Siv Fridleifsdóttir, Ordförande i Gränshinderrådet 2014 


\section{Gränshinderrådets medlemmar}
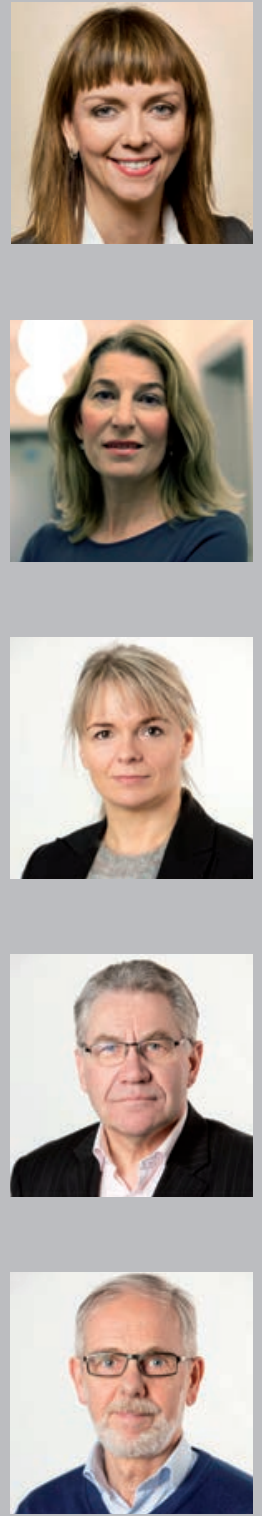

\section{Siv Fridleifsdottir • Island · Ordförande 2014}

Jag har stora förväntningar på att pröva en ny struktur för att komma vidare med arbetet mot gränshinder. De nordiska statsministrarna och Nordiska rådet har satt gränshinderfrågan högt på den politiska dagsordningen. Det finns en stark vilja att utveckla arbetet gemensamt mellan Nordiska rådet och ministrarna och det ger hopp om att vi kan nå resultat.

\section{Annika Hahn-Englund · Sverige}

Arbetet med att undanröja gränshinder i Norden har högsta prioritet för den svenska regeringen. Vår vision är ett Norden där människor och företag fritt kan verka över gränserna, obehindrat av nationella regler och bestämmelser. Genom det nya Gränshinderrådet läggs en grund för ett effektivare nordiskt gränshinderarbete. Vi välkomnar särskilt att Generalsekreteraren i Nordiska Ministerrådet har en central roll i Gränshinderrådet samt att Nordiska rådet deltar med en representant.

\section{Marjun Magnussen · Färöarna}

Fra færøsk side har vi meget glade for at deltage i Grænsehindringsrådet, og være med til at få løst grænsehindringer og forebygge, at nye opstår. Borgere og virksomheder virker på tværs af landegrænser, men dette hæmmes af grænsehindringer, og derfor er det så vigtigt at få dem løst. Et tæt nordisk samarbejde på dette område kan derfor være med til at fremme den økonomiske vækst og skabe flere arbejdspladser.

\section{Svein Ludvigsen · Norge}

I Norge har vi lav ledighet og stort behov for nordiske arbeidstakere som søker seg til norske bedrifter og offentlig sektor. Grensehinder begrenser mobiliteten i arbeidsmarkedet, og jeg ønsker gjennom Grensehinderrådet å bidra til forenkling for arbeidstakere og arbeidsgivere som krysser de nordiske grenser. Med den sterke prioriteringen Solberg-regjeringen og de nordiske statsministrene har varslet, forventer jeg at departementer og direktorater blir en offensive medspiller i dette arbeidet.

\section{Sten Palmgren · Finland}

Min förhoppning är att det inte ska finnas några gränser för fantasi och kreativitet när det gäller att göra Norden till en plats där det är lätt för människor och företag att röra sig över gränserna. Gränshinderrådet har ett tydligt politiskt uppdrag och stöd. Den nya organisationen innebär förhoppningsvis att Gränshinderrådet kan fullfölja sitt uppdrag effektivt och att rådet får en erkänd ställning som aktör i det nordiska samarbetet. 


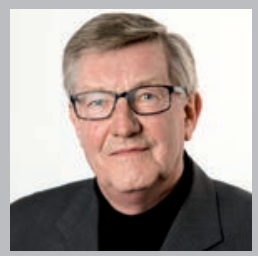

\section{Ole Stavad · Danmark}

Jeg vil i det nye Nordiske Grænsehindringsråd arbejde ihærdigt for at afdække problemområder og for at overbevise vore regeringer om værdien af at fjerne grænsehindringer og for et endnu tættere nordisk samarbejde.Norden er det største marked for vore nordiske lande og der er fortsat et stort vækstpotentiale inden for Norden. Det skal vi udnytte. Højere vækst vil skabe flere arbejdspladser og råd til bedre velfærd. Derfor skal vi afskaffe endnu flere grænsehindringer og samarbejde endnu tættere mellem vore nordiske lande.

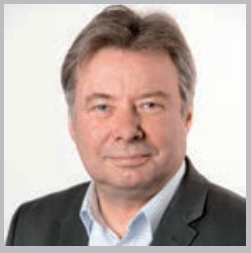

\section{Gunnar Westerholm • Åland}

Mina förväntningar på Gränshinderrådets arbete är att de underlag som finns sedan tidigare gås igenom utifrån de förslag man lagt i olika ministerråd. Förhoppningen är också att Gränshinderrådet kan upprätthålla en auktoritet mot myndigheter och ministerier så att gränshinderarbetet prioriteras på alla nivåer, och att informationens tillgänglighet lyfts som en faktor för att minska antalet gränshinder, och att alla hinder, oavsett hur många eller få som drabbas, får en objektiv bedömning hur man bästa arbetar vidare med dem.

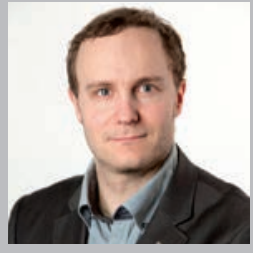

\section{Christian Wennecke · Grönland}

I Grønland er til- og fra-flytningen så stor, at knap 5 \% af befolkningen 'skiftes ud' hvert år. Grænsehindringer påvirker altså potentielt en ret stor andel af befolkningen.Vi forventer at der vil komme ukendte grænsehindringer frem i lyset, og at vi gennem arbejdet i Grænsehindringsrådet kan gøre livet nemmere for mange grønlændere og grønlandske virksomheder.

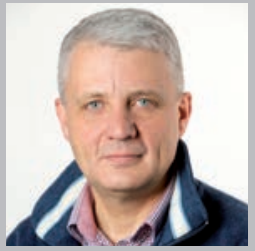

\section{Dagfinn Høybraaten · Nordiska ministerrådet}

Den nye Grensehindringsrådet har en unik sammensetning av folk med tung politisk, faglig og administrativ bakgrunn. Jeg har stor tro på at vi sammen kan løse flere grensehindringer i samspill med dem som lager lover og regler i de nordiske land. Et grenseløst Norden der innbyggerne behandles mest mulig likt og kan bevege seg fritt over landegrensene har alltid vært en bærende ide for det nordiske samarbeidet.

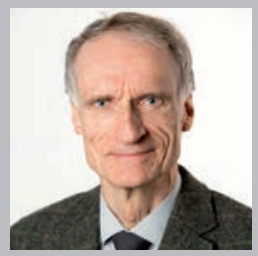

\section{Bertel Haarder · Nordiska rådet}

Grænsehindringsrådet er en historisk chance for at få gjort noget konkret ved de alt for mange nordiske grænsehindringer. Vi kender de lange lister over problemerne fra de tidligere grænsehindringsfora og fra Øresundsgruppen m.v. Opgaven er ikke at skrive nye lister. Opgaven er, at få ministrene til at insistere på, at der sker ændringer. At få dem til at sætte sagerne på dagsordenen, både i de nordiske ministerråd og i de hjemlige regeringer. De skal ikke bede om forklaringer på grænsehindringerne. De skal bede om at få forelagt mulige løsninger. 


\title{
Innehållsförteckning
}

\author{
5 Statsministerdeklaration \\ 7 Förord \\ 8 Gränshinderrådets medlemmar \\ 10 Innehållsförteckning \\ 12 Organisering av Gränshinderrådets arbete \\ 14 Gränshinderrådets mål
}

\section{Arbetsmarknad}

Status

Prioriterat av

16

Anmälan till fel A-kassa kan medföra förlorad rätt till ersättning SE

18 Arbetspraktik i ett annat nordiskt land IS

21 Rätt till tjänstledighet för politiskt uppdrag i annat nordiskt land

SE/DK

22 Långa handläggningstider (i EU-ärenden)

IS/NO

Utbildning

Prioriterat av

26 Erkännande av yrkeskvalifikationer

NMR

27 Vuxenutbildningsstöd till löntagare som blir studieledig

$\mathrm{Fl}$

30 Ingen rätt till studiestöd efter arbete utomlands

FI/AX

33 Godkännande av grönländska utbildningar

GL

\section{Socialförsäkring}

Prioriterat av

36 Sjukersättning patientresa mellan Norge och Finland/Sverige

$\mathrm{Fl} / \mathrm{NO}$

40 Finska fyramånadersregeln

$\mathrm{FI}$

42 Problem vid flytt till Island med kvalifikationsperiod på 6

IS månader om E-104 blankett saknas

44 Den norska faderskvoten

NO

48 Flytt för institutionaliserade personer

DK

50 Studerandes socialförsäkring i ett annat nordiskt land

DK 
54 Frågor om dubbelbeskattningsavtalet i förhållande till DK studiestöd

55 Dubbelbeskattning Grönland och Sverige/Finland GL

56 Rutiner för skatteinbetalning för äkta gränsgångare NO

60 Problem med fast anställda kulturarbetare i Sverige DK

62 Beskattning av dansk kapitalpension DK

Nåringsliv Prioriterat av

64 Olika byggstandarder $\mathrm{Fl} / \mathrm{AX}$

66 Eltariffer för Åland $\mathrm{AX}$

69 Erläggande av mervärdeskatt vid överförande av arbetsmaskin från Norge till Sverige

70 Norska tull- och momsregler för nordiska företag NO

72 Färöiska färdskrivarkort FO

Övrigt

Prioriterat av

76 Samordningsnummer till utländska fritidshusägare i SE Sverige

78 Erkännande av färöiska körkort FO

80 Grönländska körkort

$\mathrm{GL}$

\section{Akuta}

82 Frågan om ett möjligt upphävande av Arjeplogavtalet

83 Språkkrav för danska yrkesutbildningar

DK

85 Efterord 


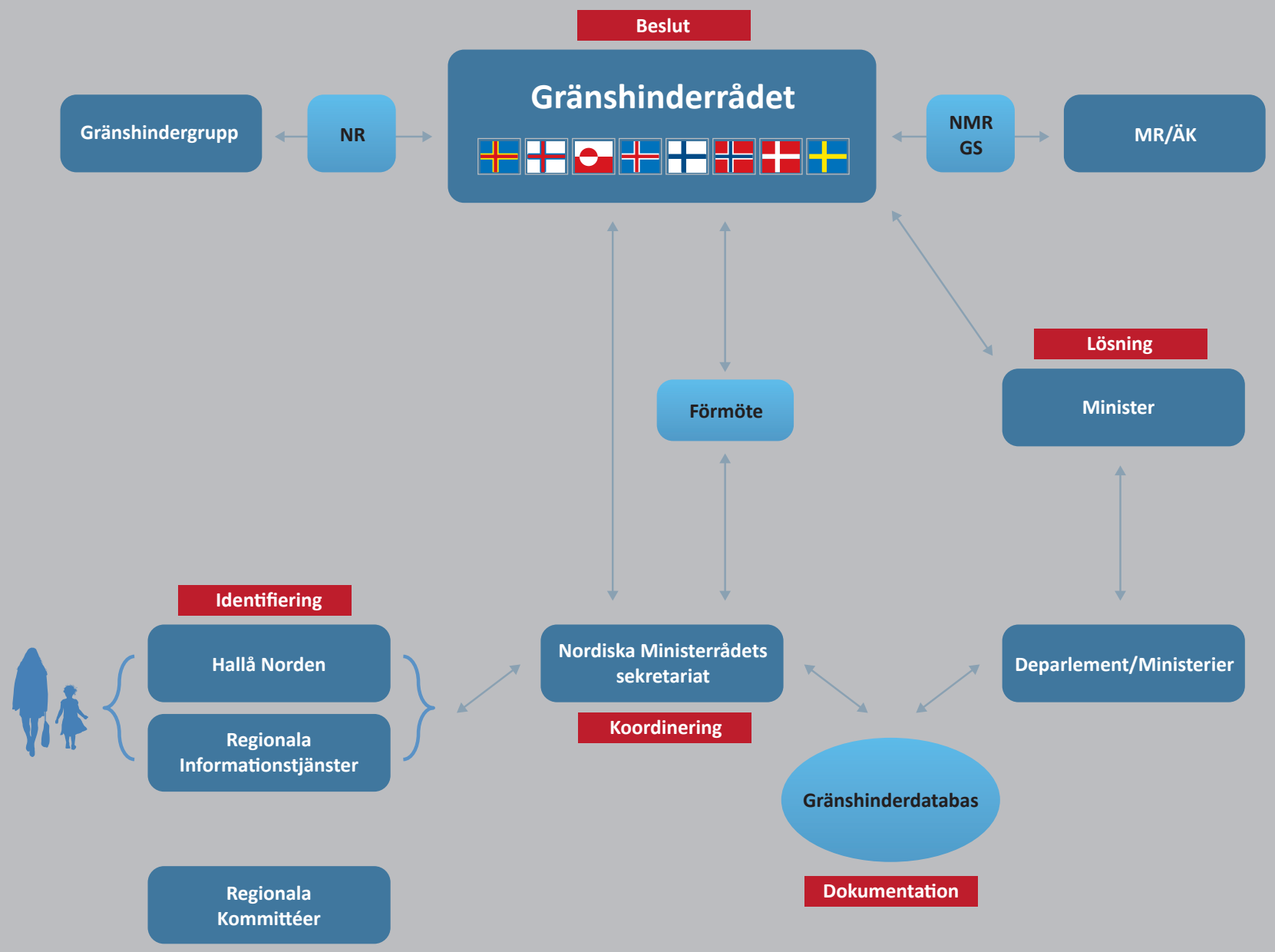




\section{Organisering av Gränshinderrådets arbete}

För att skapa transparens och delaktighet i det nordiska gränshinderarbetet mellan medborgare, företag och problemägarna är kopplingen mellan medborgarnas och företagens identifierade gränshinder i hela Norden av stor betydelse. Detta gäller regionalt och nationellt, och berör Gränshinderrådets arbete med berörda departement/ ministerier, ministeråd och parlament.

Illustrationen ger en bild av hur Gränshinderrådets arbete är organiserat.

\section{Identifiering}

Gränshinder identifieras där medborgare och företag söker information om att förflytta sig över de nordiska gränserna. För att möta medborgarnas informationsbehov har man i Norden utvecklat regionala informationstjänster Øresunddirekt, Grensetjänsten Sverige/ Norge och Nordkalottens Grenstjenst. Därutöver finns även den nordiska informationstjänsten Hallå Norden som är placerad i de nordiska huvudstäderna. Information förmedlas och hinder identifieras via webb, e-post, telefon, personlig betjäning samt informationsträffar.

\section{Koordinering}

Gränshinderrådets sekretariat mottar informationstjänsternas identifierade hinder. Samtliga identifierade gränshinder dokumenteras i den gemensamma nordiska gränshinderdatabasen. Sekretariatet ansvarar också för att koordinera Gränshinderrådets arbete och återkopplar löpande till informationstjänsterna om Gränshinderrådets arbete. Sekretariatet ansvarar också för att utvecklandet och implementeringen av en gemensam handlingsplan för informationstjänsterna i syfte öka samarbetet och effektivisera gränshinder- och informationsarbetet.

\section{Dokumentation}

Samtliga identifierade gränshinder dokumenteras i gränshinderdatabasen. Berörda departement kvalitetssäkrar innehållet i databasen.

\section{Beslut}

Baserat på de hinder som finns identifierade i gränshinderdatabasen beslutar respektive medlem i Gränshinderrådet vilka gränshinder man kommer att prioritera. Varje nationell medlem prioriterar 3-5 hinder. De nationella medlemmarna uppvaktar berörda departement och ministrar tills svar ges från berörda departement. Svaret kan antingen vara att departementet/ministeriet finner en lösning eller att man beslutat att inte gå vidare med att lösa det. Svaren från de berörda departementen/ministerierna redovisas årligen i Gränshinderrådets årsrapport. På så sätt kan man följa processen kring de prioriterade hindren.

Nordiska ministerrådets representant koordinerar information mellan Gränshinderrådets arbete och de berörda ministerråd som prioriterat samma hinder som Gränshinderrådet. Nordiska rådets representant i Gränshinderrådet kan genom parlamentarikerna i Nordiska rådet lyfta de prioriterade gränshindren i de nordiska parlamenten.

\section{Lösning}

Det är bara hos de berörda departementen en lösning på de identifierade hindren kan ske. Gränshinderrådet kan bidra till underlag som synliggör medborgarens och företags gränshinder och som hämmar mobilitet och tillväxt i Norden. Detta görs genom att ge en tydlig problembeskrivning av hindret, förslag till lösning på problem samt, i den mån det är möjligt, en kostnadsanalys av vad gränshinder kostar medborgaren och företaget. Gränshinderrådets syfte är att följa statsministerdeklarationen vad gäller gränshinder i Norden. Därför är samarbetet och den öppna dialogen med berörda departement av stor betydelse för arbetet. 


\section{Gränshinderrådets mål}

Gränshinderrådet bör rent principiellt prioritera att arbeta med de frågor som inkommer via gräsrötterna, det vill säga: Hallå Norden, Grensetjänsten, Øresunddirekt/Öresundskomiteen, Nordkalottrådet och de olika myndigheterna.

Gränshinderrådet ska främst prioritera gränshinder som uppkommer inom arbetsmarknad, social- och utbildningsområdet och som är möjliga att förändra genom avtal och regeländringar.

Målet är att få 5-10 nordiska gränshinder per år avklarade som resultat av Gränshinderrådets arbete. För att skapa långsiktighet och struktur i gränshinderarbetet bör varje medlem i Gränshinderrådet i samråd med nationella aktörer, årligen välja ut 3-5 gränshinder som skall ha högsta prioritet.

De utvalda gränshindren kommer under året att vara särskilt prioriterade och Gränshinderrådet ska driva dem tills svar avgivits från berörda departement och myndigheter. Har ingen lösning avgivits under innevarande år fortsätter dessa gränshinder att vara prioriterade fram till dess svar från berörda departement och myndigheter avgivits.

\section{Prioriterade gränshinder}

Gränshinderrådets medlemmar har var och en valt, i några fall tillsammans, att prioritera 3-5 gränshinder. Prioriteringarna presenterades under Gränshinderrådets möte den 11 april 2014, sedan dess har medlemmarna arbetat med hindren.
Gränshinderrådets medlemmar har graderat arbetet med sina prioriterade hinder enligt en färgskala med fyra nivåer.

Rött innebär att hindret för närvarande inte är prioriterat vid berörda departement/ministerier.

Gult betyder att det pågår arbete med hindret vid berörda departement/ministerier.

Grönt innebär att arbetet följer den process som respektive medlem satt upp för att få ett slutligt svar på huruvida hindret kommer att lösas eller inte.

Blått betyder att ett slutligt svar kommit och hindret avklarats. Av stämpeln framgår om hindret faktiskt blivit löst eller om länderna beslutat att avskriva hindret och inte arbeta vidare för att hitta en lösning.

Årsrapporten 2014 är en status över de hinder som prioriterats av respektive medlem i Gränshinderrådet. Det är viktigt att notera att hindren är i process och därmed kan deras status vara annorlunda vid tidpunkten för läsandet. Det kan dessutom finnas andra bedömningar av de prioriterade hindren från de nordiska länderna än vad som anges av Gränshinderrådets medlem.

\section{Om beräkningarna}

Vid beräkningen av kostnaderna har vi så långt det har varit möjligt använt oss av befintlig statistik. I de fall ingen statistik har funnits har vi gjort uppskattningar utgående från existerande statistiska uppgifter. I enskilda fall har vi varit tvungna att göra antaganden för att kunna illustrera kostnaderna. I de fallen nämns detta skilt i samband med beräkningarna. 


\section{Hinder på arbetsmarknadsområdet}




\section{Anmälan till fel A-kassa kan medföra förlorad rätt till ersättning}

\section{Personer som blir arbetslösa kan förlora rätten till inkomstbortfallsförsäkring om de ansöker om medlemskap i fel a-kassa. Det gäller både personer som mister sitt svenska jobb och gränsarbetare}

Ett prioriterat gränshinder av Annika Hahn-Englund, Sverige. Även prioriterat av MR-A. Hindret kan lösas av Arbetsmarknadsdepartementet.

\begin{abstract}
Bakgrund
För en gränsarbetare som är bosatt $\mathrm{i}$ Sverige och arbetar i Danmark gäller Danmarks lagstiftning för social trygghet. Om personen blir helt arbetslös gäller i stället bosättningslandets lagstiftning. För att erhålla inkomstbortfallsförsäkring från den svenska arbetslöshetsförsäkringen krävs enligt praxis ett medlemskap i svensk arbetslöshetskassa under en obruten tolvmånadersperiod. Personen kan tillgodoräkna sig försäkringsperioder från tiden i Danmark som då likställs med medlemskap i svensk arbetslöshetskassa.
\end{abstract}

Problem kan uppstå vid övergången från arbetslandets arbetslöshetsförsäkring till bosättningslandets arbetslöshetsförsäkring. För att i Sverige få tillgång till inkomstbortfallsförsäkringen, krävs medlemskap i en svensk arbetslöshetskassa. Om en gränsarbetare eller annan person återvänder till
Sverige efter arbete inom EU/EES måste han eller hon ansöka om medlemskap i en svensk arbetslöshetskassa omedelbart i samband med övergången mellan länderna. Om personen inte ansöker direkt kan ett avbrott i den pågående perioden uppkomma. Det är avbrottet i medlemskapet som är orsaken till att personen förlorar rätten till ersättning från inkomstbortfallsförsäkringen. Det i sin tur leder till att personen inte uppfyller medlemsvillkoret enligt svensk lagstiftning och han eller hon kan då enbart få ersättning enligt grundförsäkringen. (Texten tagen från SOU 2011:74.)

Förutom kravet på att arbetstagaren omedelbart ska anmäla sig till en arbetslöshetskassa, ska anmälan dessutom ske till rätt a-kassa. Det innebär att en person som borde tillhöra Akademikernas a-kassa, men anmält sig till Ledarnas a-kassa, inte uppfyller kravet på att omedelbart ha anmält sig till rätt a-kassa. Förutom den ovan beskrivna situationen gällande gränsarbetare kan samma problem även uppstå i rent interna situationer inom Sverige.

\section{Vem påverkas}

Gränspendlare bosatta i Sverige som nyligen blivit helt arbetslösa och söker arbetslöshetsersättning i Sverige. Även personer som bott och arbetat i Sverige kan drabbas av ett avbrott vid byte av medlemskap från en a-kassa till en annan, om det uppstår ett uppehåll $\mathrm{i}$ medlemskapet.

\section{Ekonomiska konsekvenser}

Johan bor i Sverige och arbetar i Danmark, han har en lön på DKK 30.000 i månaden och betalar varje månad in DKK 443 till sin danska a-kassa. Johan blir helt arbetslös och ska då anmäla sig till den svenska a-kassan. Tyvärr anmäler han sig till fel a-kassa i Sverige. 


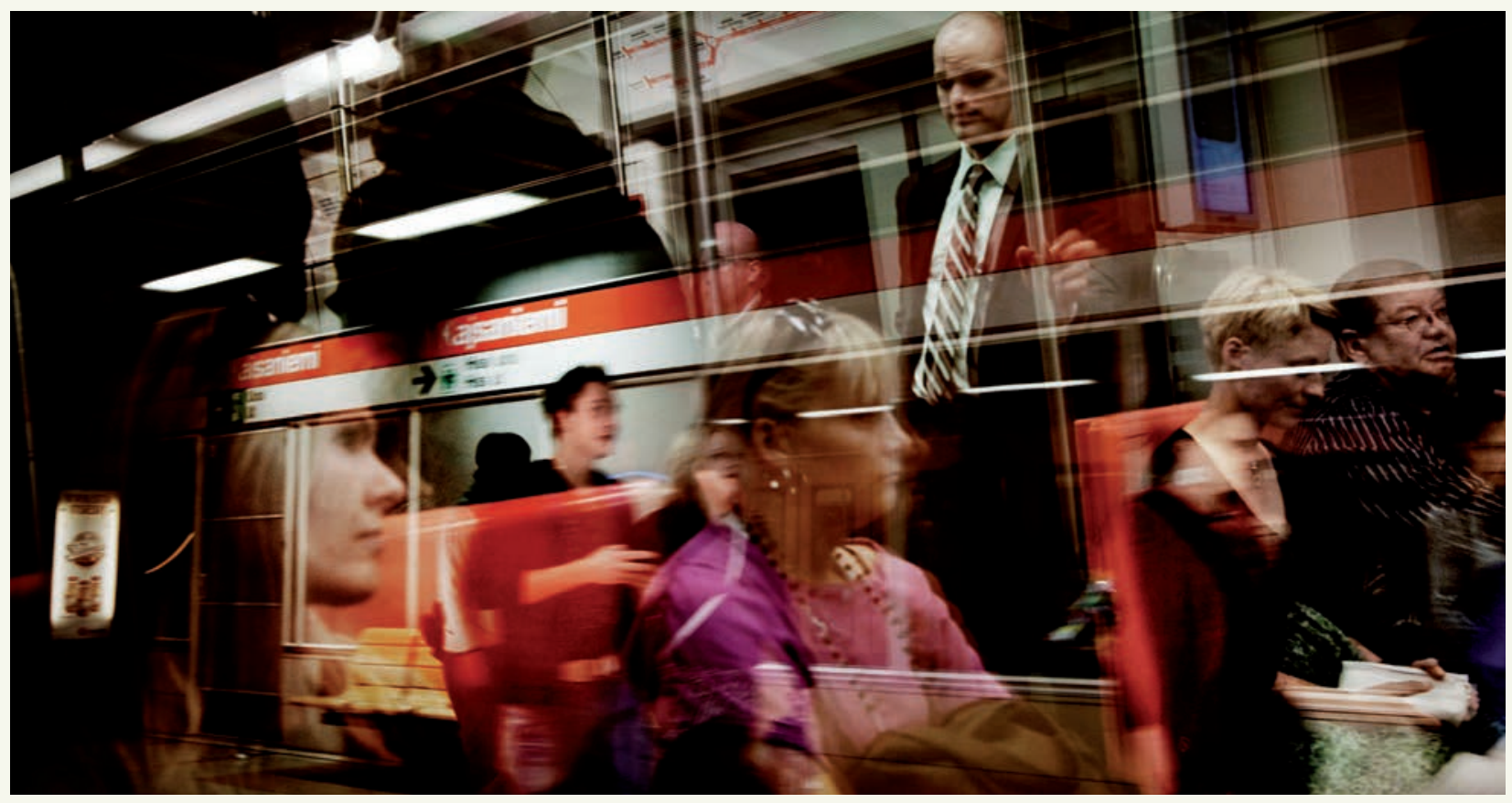

När Johan anmäler sig till rätt a-kassa kommer han att kunna bli medlem. Om det har uppstått ett glapp i försäkringsperioden kommer Johan inte att få ersättning från inkomstförsäkringen.

Det betyder att Johan inte kan få maximal a-kassa på SEK 14.960 som han är berättigad till utan endast SEK 7.040 före skatt. Han går således miste om SEK 7.920 per månad.

\section{Förslag till lösning}

Inför 4-veckorsregel för personer som ansöker medlemskap i svensk a-kassa. Det betyder att man ger både den som ansöker om medlemskap och a-kassorna, möjlighet att under dessa fyra veckor finna rätt a-kassa åt den arbetssökande utan att personen ifråga blir utförsäkrad på grund av en bruten 12 månadsperiod.

\section{Gränshinderrådets arbete med frågan}

Under våren 2014 har Gränshinderrådets svenska representant varit i kontakt med regeringskansliet i Sverige.

\section{Nuvarande status}

Den parlamentariska socialförsäkringsutredningen har i uppdrag av regeringen att utreda bl.a. denna fråga. Socialförsäkringsutredningen kommer att redovisas senast $\mathrm{i}$ januari 2015.

Utredningen kommer därefter att utgöra grunden för regeringens ställningstagande.

\section{Nästa steg}

Under hösten 2014 kommer Gränshinderrådet att följa upp och bevaka den vidare processen.

\section{Kommentarer från berörda regeringar}

Gränshinderrådets svenska medlem har inte begärt kommentarer gällande detta hinder.

Läs mer i Gränshinderdatabasen, granshinder.norden.org, gränshinder nr: 14-150. 


\section{Arbetspraktik i ett annat nordiskt land}

\section{En person som är arbetslös kan inte genomföra praktik i ett annat nordiskt land, eftersom de nationella regelverken primärt baseras på att praktik genomförs i bosättningslandet}

Ett prioriterat gränshinder av Siv Friðleifsdóttir, Island. Detta hinder har prioriterats och behandlats av MR-A.

Hindret finns med i det danska avtalet mellan Folketinget och regeringen.

Hindret kan lösas av de nordiska arbetsmarknadsdepartementen och arbetsmarknadsministerierna.

\section{Bakgrund}

Ett huvudsyfte med den lagstiftning som gäller för regler och bestämmelser för arbetsförmedling och arbetslöshetsersättning är att personer som får ersättning vid arbetslöshet, ska komma in på, eller återinträda på, arbetsmarknaden.

Alla länder har regler som innebär att personer som får arbetslöshetsersättning kan få ersättning under en praktikperiod hos en arbetsgivare, eller så kan arbetsgivaren få ett bidrag. Syftet är att säkra en aktiv politik för att få in arbetssökande på arbetsmarknaden eller att säkra återinträde på arbetsmarknaden. Målen för praktik är t.ex. förtydligade sysselsättningsmål, att arbetssökande får arbetslivserfarenhet, att underlätta återgång $\mathrm{i}$ arbete eller att insatsen ska stärka kompetensen.

Som utgångspunkt kan åtgärderna endast ske i det land där den arbetssökande är bosatt.
Detta hinder har lyfts särskilt i gränsregioner, där arbetsmarknaden på båda sidor av gränsen är stängd för en arbetssökande som skulle kunna få praktik i ett annat land. I de situationer, då en arbetssökande har en utbildning från ett annat land, eller primärt behärskar språket i det andra landet kan ett inträde eller ett återinträde på arbetsmarknaden försvåras när det uteslutande fokuseras på bosättningslandet. En utvidgad möjlighet till arbetspraktik i ett annat land kan också förbättra möjligheterna till konjunkturutjämning på arbetsmarknader med olika sysselsättningsnivåer.

\section{Vem påverkas}

En lösning av detta hinder innebär att personer bosatta i de nordiska länderna, särskilt i gränsregionerna, kan få arbetspraktik i ett annat nordiskt land. Situationen kompliceras av att arbetsmarknadsåtgärden arbetspraktik finns i olika former i de olika länderna, vilket i sig också försvårar möjligheterna att hitta en lösning på hindret.

\section{Ekonomiska konsekvenser}

Camilla är arbetssökande i Finland, Torneå, men söker arbetspraktik i Sverige, Haparanda. Detta är inte möjligt idag då arbetsprövning (den finska motsvarigheten till arbetspraktik) är kopplad till boendelandet.

Beräkningarna baseras på en dansk undersökning från Arbejdsmarkedsstyrelsen, enligt undersökningen kommer 28 procent av de som varit $i$ arbetspraktik $i$ arbete tack vare möjligheten till arbetspraktik. Med utgångspunkt att denna undersökning är representativ för hela Norden, kommer Camillas möjlighet att få arbete efter praktiken i ett annat nordiskt land att vara 28 procent.

Den samhällsekonomiska vinsten per år genom att få Camilla i arbete är EUR 60.400 för Sverige, då Camilla genom 
sitt svenska arbete bidrar till att öka den svenska BNP. Finland å sin sida sparar EUR 23.700 i arbetslöshetsersättning under förutsättning att Camilla tidigare hade en inkomst på EUR 3.800 i månaden.

Genom att lösa detta hinder kommer medborgare som lever i de nordiska gränsregionerna att få möjlighet att söka arbetspraktik på en större arbetsmarknad. I de exempel som finns nedan blir det geografiska området där man kan få tillgång till arbetspraktik totalt sett $100 \%$ större än i dagsläget om hindret blir löst.

\section{Förslag till lösning}

I en rapport från Rambøll gällande arbetsmarknadspraktik konstaterades att en tänkbar lösning kunde vara att försöka genomföra bilaterala projekt i gränsregionerna. Det är dock inte klarlagt om de nordiska länderna kan göra en särskild överenskommelse kring detta utan att även övriga EU- och EES-länder involveras.

\section{Gränshinderrådets arbete med frågan}

Under våren och sommaren har

Gränshinderrådets isländska medlem

undersökt vilken status detta hinder har på Island.

\section{Nuvarande status}

- Danska Rambøll har på uppdrag av ÄK-A undersökt gränshindret. Baserat på rapportens slutsatser har ÄK-A inställt till MR-A att gränshindret ska tas bort från A-sektorns prioriteringslista. Beslutet om ett borttagande skulle avgöras genom skriftlig procedur, men fick inte få medhåll från Island.

- Rambøll-rapporten nämner möjligheten att "man indledningsvist gennemfører et eller flere pilotprojekter inden der åbnes for muligheden for tværnordisk arbejdspraktik”. Detta nämns även i Femtiosex nordiska kombinationer - strategi och handlingsplan för nordisk mobilitet 20142017, som mer specifikt tar upp "ett danskt-svenskt pilotprojekt med arbetsplatspraktik över gränserna i Öresundsregionen".

- Frågan om arbetspraktik ska även behandlas i Nordiska rådets Gränshindergrupp.

- Gränshindret var på dagordningen på MR-A möte i Köpenhamn den 20 november 2014 och länderna beslutade gemensamt att inte arbeta vidare med frågan om arbetspraktik. Gränshinderrådets sekretariat arbetar därför i dagsläget inte vidare med detta hinder.

\section{Kommentarer från relevanta regeringar}

I arbetet med att lösa gränshinder inom MR-A:s ansvarsområde har gränshindret "C1: Arbetspraktik i ett annat nordiskt land" följts upp av ÄK-A. En 
konsekvensanalys har genomförts av Ramböll som belyser vilka åtgärder som skulle behöva vidtas och vilka regelverk som borde förändras för att möjliggöra arbetspraktik över gränserna. Gränshindret togs up på ett statsekreterarmöte som anordnades istället för uppskjutet MR-A möte den 21 maj i Reykjavik 2014. På mötet framkom att länderna, utifrån resultaten av konsekvensanalysen, inte fann något intresse att arbeta vidare med att möjliggöra arbetspraktik över gränserna. Eftersom mötet inte var beslutsför föreslågs ett särskilt per capsulam-beslut av MR-A i frågan före den 28 augusti 2014.

\section{Beräkningar}

Den samhällsekonomiska vinsten för Sverige är beräknad som bruttotillväxten per anställd inom handelsbranschen $\mathrm{i}$ Norrbotten.
I skriftligt svar den 2.9. 2014, från den isländska social- og bostadsminister, framkom: „Minister Eygló Hardardóttir föreslår att MR-A väntar med att gränshindret C1: Arbetspraktik i ett annat nordiskt land tas bort från listan över prioriterade gränshinder inom MR-A:S ansvarsområde. Följande uttalande önskar ministern att bifogas med svaret från Island:

"Det har kommet till min kännedom att en av de gränshinder som Gränshinderrådet har på sin prioriteringslista är gränshinderet „Arbeidspraktik i ett annat nordiskt land“. Av den och flera grunder vill jeg gärna att vi, ministerna, beslutar att inte ta bort det i skriftlig procedur från listan over prioriterade gränshinder inom MR-A:s ansvarsområde. I stället vill jag gjärna att vi tar det opp på vårt näste möte till diskussion om det är möjligt att arbeta videre med saken.”,

Gränshindret var på dagordningen på MR-A möte i Köpenhamn den 20 november 2014 och länderna beslutade gemensamt att inte arbeta vidare med frågan om arbetspraktik.

Läs mer i gränshinderdatabasen, granshinder.norden.org, gränshinder nr: 14-002.

\section{Exempel på utökade möjligheter till fler potentiella arbetspraktikplatsanordnare i tre gränsregioner}

\begin{tabular}{|lrrr|}
\hline Arbetsmarknad & I dag & Löst hinder & Ökad storlek på arbetsmarknad \\
Köpenhamn & 919.000 & 1.403 .400 & $53 \%$ \\
Malmö-Lund & 483.500 & 1.403 .400 & $190 \%$ \\
Haparanda & 3.700 & 12.500 & $238 \%$ \\
Torneå & 8.800 & 12.500 & $42 \%$ \\
Strömstad & 11.900 & 25.600 & $115 \%$ \\
Halden & 13.700 & 25.600 & $87 \%$ \\
Totalt & & & $100 \%$ \\
\hline
\end{tabular}




\title{
Rätt till tjänstledighet för politiskt uppdrag från arbete i annat nordiskt land
}

\author{
Den som bor i ett nordiskt land och arbetar i ett annat, har inte rätt till \\ tjänstledighet för politiskt arbete i bosättningslandet. Detta kan vara ett \\ hinder för att ta politiska uppdrag
}

Ett prioriterat hinder av Annika Hahn-Englund, Sverige och Ole Stavad, Danmark.

Hindret finns med i det danska avtalet mellan Folketinget och regeringen.

Nordiska ministerrådets sekretariat samt berörda ministerier har arbetat med detta gränshinder.

\begin{abstract}
Bakgrund
I de nordiska länderna finns regler om att förtroendevalda har rätt att få tjänstledigt från arbetet för att utföra politiskt arbete som de har valts till. Denna rätt gäller endast om personen bor, arbetar och utför politiska uppdrag i samma land. En gränsarbetare som blir förtroendevald i sitt bosättningsland har således inte motsvarande rätt till tjänstledighet i sitt arbetsland för att utföra sitt politiska uppdrag i bosättningslandet.
\end{abstract}

\section{Vem påverkas}

Detta hinder berör främst personer som daglig-/veckopendlar, totalt ca. 70.000 personer.

\section{Förslag till lösning}

En gränsarbetare som är förtroendevald i bosättningslandet skulle eventuellt kunna, genom att de nationella reglerna skrivs om för att även gälla personer med arbete i landet och politiskt uppdrag i grannlandet eller genom bilaterala avtal, ges rätt att få tjänstledighet för att utföra politiskt arbetet $\mathrm{i}$ bosättningslandet utifrån arbetslandets tjänstledighetsregler.

\section{Gränshinderrådets arbete med frågan}

Företrädare för Sverige, Danmark, Norge och Finland har under koordinering av Nordiska ministerrådets gränshinderrådssekretariat undersökt förutsättningarna för tjänstledighet för politiskt uppdrag i annat nordiskt land.

- På det nordiska informella kommunministermötet i Oslo den 14 augusti skrev deltagarna under en deklaration om att man vill verka för att underlätta för förtroendevaldas ledighet i Norden.
- Nu ska en utredning göras om behovet av ett bilateralt avtal mellan Sverige och Danmark för att komma vidare med lösningsarbetet.

- Danmarks ekonomi- och inrikesminister har i ett brev till den danska samarbetsministern meddelat att man ska lägga fram ett lagförslag i början av nästa folketingssamling som kommer lösa gränshindret från dansk sida.

\section{Kommentarer från berörda regeringar}

Gränshinderrådets svenska medlem har inte begärt kommentarer gällande detta hinder.

Läs mer i Gränshinderdatabasen, www.norden.org gränshinder nr: 14132. 


\title{
Långa handläggningstider (i EU-ärenden)
}

\author{
I de nordiska länderna varierar handläggningstiden för att besluta om social- \\ och arbetslöshetsförsäkringsförmåner. I EU-ärenden kan handläggningstiden \\ bli längre eftersom behörig institution kan behöva hämta in uppgifter från \\ motsvarande institution i ett annat land. Detta kan ge försörjningssvårigheter \\ för den enskilde
}

Ett prioriterat gränshinder av Svein Ludvigsen, Norge och Siv Friðleifsdóttir, Island. Även prioriterat av MR-A. Hindret kan lösas av handläggande myndigheter i samtliga nordiska länder och självstyrande områden.

\author{
Bakgrund \\ Hindret har kartlagts i rapporten \\ "Gränshinder i Norden på social- och \\ arbetsmarknadsområdet" (Nord \\ 2012:002). Kartläggningen omfattade \\ ärenden med EU-rättslig koppling, bl.a. \\ ansökningar om arbetslöshets- och \\ familjeförmåner, pensioner och sjuk- \\ dagpenningar.
}

Rapporten visar att handläggningstiderna ofta är betydligt längre då sökanden bott och/eller arbetat utomlands jämfört men då sökanden hållit sig inom hemlandets gränser. Orsaken till de långa handläggningstiderna är att de nationella myndigheterna måste samla in information om sökandens arbetsoch försäkringsförhållanden från sina utländska myndighetskolleger för att kunna avgöra ärendet.

Trots att det finns klara EU-regler som förpliktigar medlemsstaternas myndig- heter att samarbeta, så finns det brister i informationsflödet dem emellan. Konsekvensen är att handläggningstiderna förlängs, något som resulterar i att gränsgångare tvingas leva i långa perioder av ovisshet och att de i värsta fall kan råka ut för försörjningssvårigheter.

\section{Vem påverkas}

Detta hinder påverkar hundratusentals medborgare och berör i första hand de personer som arbetar eller har arbetat i ett land och bor i ett annat. Främst rör det sig om personer som dagligen pendlar över en nationsgräns.

\section{Ekonomiska konsekvenser}

Gertrud som bor i Sverige, har jobbat i Norge, och blir helt arbetslös, och ska därför få sin arbetslöshetsersättning från Sverige. Det maximala beloppet uppgår till SEK 14.960 före skatt, cirka SEK 10.472 efter skatt. Handläggningstiden inom Sveriges gränser är vanligen fyra veckor, men eftersom Gertrud jobbat i Norge måste hon vänta i ytterligare 24 veckor, ca. 5,5 månader, på ett beslut från a-kassan. För att säkra sin försörjning under väntetiden tar hon varje månad ett lån på SEK 10.000 . Räntan på lånet är $6,95 \%$ och årsavgiften $2 \%$ av det belånade beloppet. De totala lånekostnaderna för Gertrud uppgår därmed till SEK 1.600. Närmare beräkningar finns nedan.

Detta är ett exempel på en privatperson som drabbas av handläggningstider som är längre än för personer som verkar och bor i samma land. Med tanke på att nordborna har 56 möjligheter att korsa en nordisk gräns samt att handläggningstiderna bland annat innefattar arbetslöshets-, sjukförsäkrings-, pensions- och föräldraförmåner, så finns goda belägg för att den samlade kostnaden för berörda personer runtom i Norden blir hög. 


\section{Beräkningar}

Arbetslöshetsersättning/månad, före skatt

14.960 SEK

Arbetslöshetsersättning/månad, efter 30 \% skatt

10.472 SEK

Totalbelopp för 5,5 månader

Lån från bank, månad för månad, ränta 6,95\%

Månad 1 (ränta betalas för 24 veckor)

Månad 2 (ränta betalas för 20 veckor)

Månad 3 (ränta betalas för 16 veckor)

Månad 4 (ränta betalas för 12 veckor)

Månad 5 (ränta betalas för 8 veckor)

Månad 5,5 (halva beloppet, ränta betalas för 4 veckor)

Totalt

Årsavgift, 2\% av det belånade beloppet, för 5,5 månader

$\begin{array}{rlrl}\text { Belopp } & \text { Ränta } \\ 10.000 & \text { SEK } & 321 & \text { SEK } \\ 10.000 & \text { SEK } & 267 & \text { SEK } \\ 10.000 & \text { SEK } & 214 & \text { SEK } \\ 10.000 & \text { SEK } & 160 & \text { SEK } \\ 10.000 & \text { SEK } & 107 & \text { SEK } \\ 5.000 & \text { SEK } & 27 & \text { SEK } \\ 55.000 & \text { SEK } & 1.096 & \text { SEK }\end{array}$

504 SEK

Totala lånekostnader pga. långa handläggningstider

\section{Förslag till lösning}

Tre lösningsförslag:

1. Gemensamma rutiner för handläggning

2. Fler personalresurser

3. Möjlighet till att följa handläggningsprocessen

\section{Gränshinderrådets arbete med frågan}

Gränshinderrådets medlemmar kommer i bilaterala kontakter med berörda ministrar i sina respektive länder att undersöka vilka konkreta tilltag som görs för att förkorta handläggningstiderna.
Detta hinder har tagits upp skriftligt genom brev till det norska utrikesdepartementet som ansvarar för EES-ärenden och kopplingen till EU. Under fjärde kvartalet 2014 kommer ärendet att följas upp genom att be om ett möte med departementet. I december 2014 har Gränshinderrådets norske medlem följer upp detta ärende med den norska samarbetsministern och berört departement som ska återkomma med svar på frågan. Gränshindret kommer även att lyftas till Nordiska rådets norska delegation 3 februari 2015.

\section{Kommentarer från berörda regeringar \\ UD har oversendt saken till Helse og sosialdepartementet som skal gi svar. \\ Läs mer i Gränshinderdatabasen, granshinder.norden.org, gränshinder nr: 14-042.}




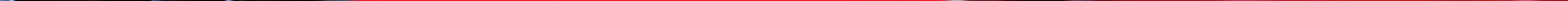




\section{Hinder på utbildningsområdet}




\section{Erkännande av yrkeskvalifikationer}

\section{Många yrken i Norden är reglerade antingen från statligt håll, exempelvis i lag eller genom branschspecifika föreskrifter. Eftersom kraven skiljer sig mellan de nordiska länderna uppstår det hinder för arbetstagarnas fria rörlighet}

Ett prioriterat gränshinder av Dagfinn Høybråten, Nordiska ministerrådet, Bertel Haarder, Nordiska rådet, samt av MR-U och MR-NER.

Arbetet med hindret kräver koordinering mellan de nordiska arbetsmarknads- och utbildningsministerierna.

\begin{abstract}
Bakgrund
Nordiska ministerrådet har som en del av programmet Hållbar nordisk välfärd, låtit konsultföretaget DAMVAD göra analysen "Lovregulerede erhverv og velfærdsprofessioner". Det är en rapport som bland annat kartlägger alla statligt reglerade yrken i Norden. Resultaten visar att antalet reglerade yrken varierar stort mellan de nordiska länderna; Island med 171 statligt lagreglerade yrken har flest, Norge har 165 och Danmark 162. Sverige har 91 och Finland 74. Analysen visar också att de yrken som är statligt reglerade ger färre gränshinder än de som är branschspecifikt reglerade.
\end{abstract}

\begin{abstract}
Arbetet med gränshindret är nära kopplat till implementeringen av EU:S nya yrkeskvalifikationsdirektiv. Det är dock svårt att hitta en slutlig lösning på gränshindret, eftersom problematiken rör många branscher och många länder.

Gränshinderrådet har därför valt en mer långsiktig strategi och fokuserar
\end{abstract}

sitt arbete på att underlätta en samnordisk implementering av direktivet. På sikt kommer en ökad koordinering av implementeringen av direktivet förhoppningsvis att bidra till ett minskat antal problem på grund av skillnader i kvalifikations- och utbildningskrav.

De tjänstemän som arbetar med implementeringen har träffats en gång i Köpenhamn under våren och det kommer att ordnas ett andra möte i början av 2015.

\section{Förslag till lösning}

Underlätta erfarenhetsutbyte under genomförandefasen av EU:s yrkeskvalifikationsdirektiv.

\section{Gränshinderrådets arbete med frågan \\ Nuvarande status}

- Den 26 maj hölls ett möte vid Nordiska ministerrådets sekretariat i Köpenhamn där de tjänstemän som ansvarar för implementeringen av yrkeskvalifikationsdirektivet diskuterade nationella processer och utmaningar. En utmaning är det faktum att olika yrken är reglerade i de olika länderna och att regleringsteknikerna också ser olika ut, dessutom medverkar ett stort antal ministerier/ departement.

\section{Nästa steg}

- Ett nytt möte med tjänstemannagruppen kommer att hållas i början av 2015.

- Nordiska ministerrådets sekretariat arbetar vidare med att säkra ett klart, politiskt mandat för det vidare arbetet, där målet är en så likartad implementering av direktivet som är politiskt och praktiskt möjligt.

\section{Kommentarer från berörda regieringar}

Kommentarer har ej begärts för detta hinder.

Läs mer i gränshinderdatabasen, granshinder.norden.org, gränshinder nr: 14-122. 


\title{
Vuxenutbildningsstöd till löntagare som blir studieledig
}

\author{
Gränsarbetare som bor i Finland, men som har arbetat en kort period \\ utomlands under de senaste åtta åren innan hon eller han lämnar in en \\ ansökan om vuxenutbildningsstöd i Finland, är inte berättigad till stödet
}

Ett gränshinder prioriterat av Sten Palmgren, Finland.

Hindret kan lösas av Social- och hälsovårdsministeriet.

\begin{abstract}
Bakgrund
Det grundläggande kravet för att en person bosatt i Finland ska vara berättigad till finskt vuxenutbildningsstöd är att hon/han varit pensionsförsäkrad $i$ en oavbruten period om åtta år i Finland. Det kravet är uppfyllt om personen har en arbetshistoria som sträcker sig minst åtta år bakåt, där det senaste arbetsförhållandet ska ha varat i minst ett år och omfatta minst 18 timmars arbete per vecka. I sådana fall har personen rätt till vuxenutbildningsstöd om hon eller han vill studera i minst två månader och inte får annat stöd för sina studier.

En finsk arbetstagare som bor i Finland, men som jobbat utomlands under de senaste åtta åren tappar dock sin rätt till finskt vuxenutbildningsstöd. Orsaken är att arbete utanför Finlands gränser gör att personen blir pensionsförsäkrad i sitt arbetsland. Det innebär att det blir ett avbrott i personens tid som pensionsförsäkrad i Finland, vilket innebär att personen mister rätten till
\end{abstract}

vuxenutbildningsstöd. Således har en gränsarbetare inte samma ekonomiska förutsättningar för vidareutbildning som en arbetstagare som enbart jobbat $i$ Finland.

\section{Vem påverkas}

Detta hinder påverkar potentiellt samtliga medborgare som bor i Finland, men som arbetat utomlands under de senaste åtta åren.

\section{Ekonomiska konsekvenser}

En person som beviljas vuxenutbildningsstöd får i snitt EUR 7,369 (2013). Omkring 1,900 personer/år får avslag på deras ansökan om vuxenutbildningsstöd. Det finns dock inga siffror på hur många avslag som beror på att av kravet på en oavbruten pensionsförsäkringsperiod om åtta år i Finland inte är uppfyllt. Om antagandet är, att det är grunden till $10 \%$ av avslagen, innebär det att 190 personer inte ges vuxenutbildningsstöd. Genom att inte betala ut vuxenutbildningsstöd åt dessa 190 personer sparar finska staten således ca. EUR 1,4 miljoner/år. Närmare beräkningar finns nedan.

\section{Förslag till lösning}

Istället för de förutsättningar som nämns ovan kunde utgångspunkten vara att den som söker vuxenutbildningsstöd ska uppfylla de s.k. arbetsvillkoren för löntagare. Personen skulle i så fall beviljas stöd om hon eller han har förvärvsarbetat i 26 veckor under de 28 senaste månaderna (granskningsperiod), arbetat minst 18 timmar i veckan och haft en på lön minst 1154 euro/månad.

\section{Gränshinderrådets arbete med frågan \\ Etablerat kontakter med de ansvariga tjänstemännen vid Social- och hälso- vårdsministeriet. Enligt de ansvariga tjänstemännen kräver frågan lag- ändring. Arbetet kan dock påbörjas tidigast efter riksdagsvalet 2015.}




\section{Kommentarer från berörda regeringar}

Enligt de ansvariga tjänstemännen på Social- och hälsovårdsministeriet kräver frågan lagändring. Arbetet kan dock påbörjas tidigast efter riksdagsvalet 2015.

Läs mer i Gränshinderdatabasen, granshinder.norden.org, gränshinder nr: 14-158.

\section{Beräkningar}

Utbildningsstyrelsen har levererat upplysningar om beviljade vuxenutbildningsunderstöd - både antal personer och utbetalda belopp, samt dessutom uppgifter om hur många personer som har fått sin ansökan avslagen.
Det saknas information om hur många ansökningar som har avslagits p.g.a. att den som ansökte inte hade varit pensionsförsäkrad i åtta år. Därför är de $10 \%$ enbart ett exempel.

Antal personer som beviljats vuxenutbildningsstöd 2013

Totala utbetalningar av vuxenutbildningsstöd 2013

15.362 personer

Beviljat belopp per person

$113.200 .000 €$

$7.369 €$

Antal personer som får avslag på sin ansökan om vuxenutbildningsstöd

1.900 personer

Antagande: $10 \%$ av avslagen beror på att kravet om en obruten pensions-

försäkringsperiod inte är uppfyllt

Antal personer som drabbas av gränshindret

190 personer

Totalkostnad för att lösa hindret (beviljat belopp x antal drabbade) 


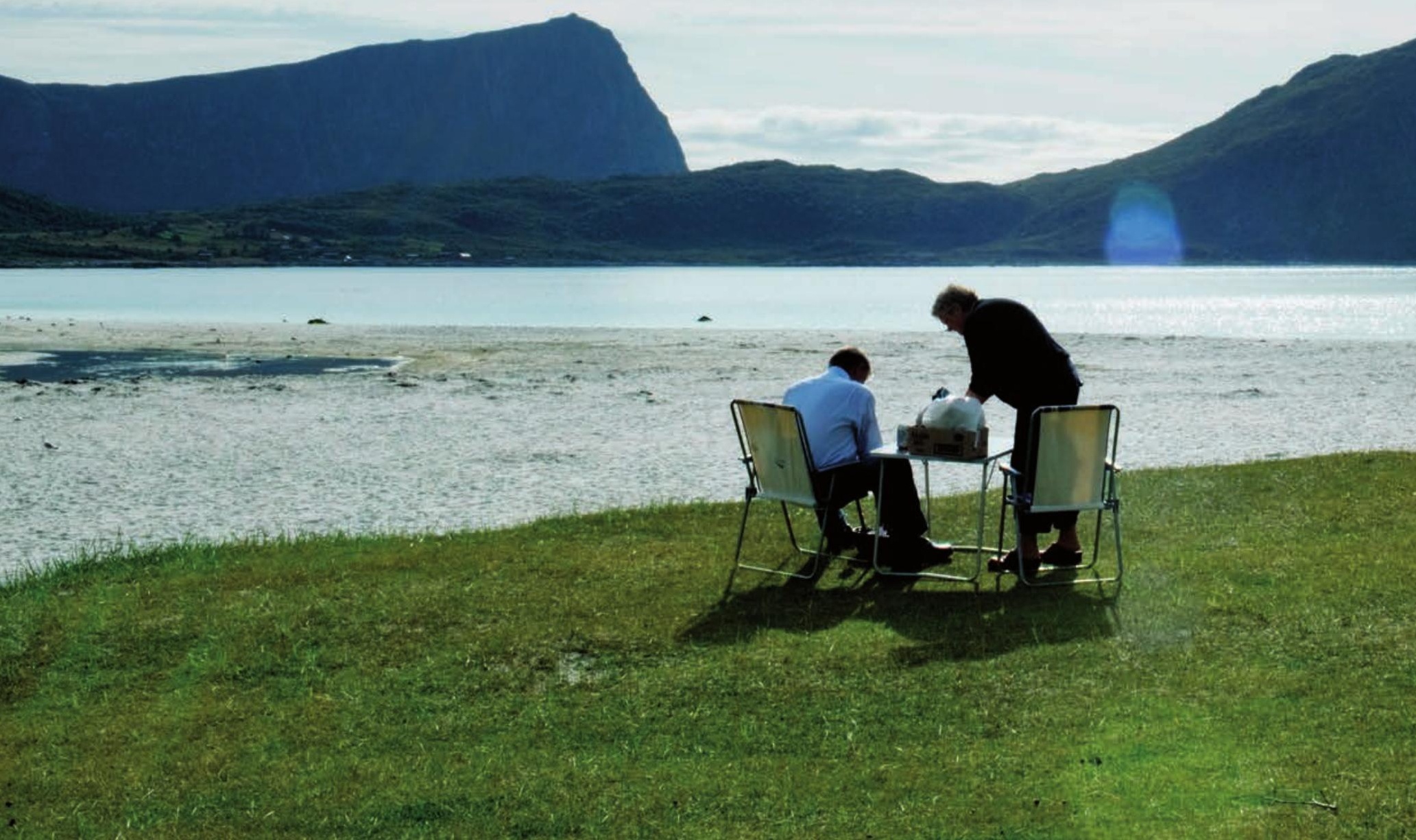




\title{
Ingen rätt till studiestöd efter arbete utomlands
}

\author{
De flesta nordiska länder har ett bosättningskrav i sin studiestödslagstiftning. \\ För att ha rätt till studiestöd måste sökanden därför i regel ha bott två av de \\ senaste fem åren i sitt hemland. Det gör att personer som rört sig över gränser- \\ na och jobbat i ett annat land kan ha svårigheter att få studiestöd
}

Ett gränshinder prioriterat av Sten Palmgren, Finland och Gunnar Westerholm, Åland.

Hindret kan lösas av Folkpensionsanstalten samt undervisnings- och kulturministeriet (Finland), Styrelsen for Videregående Uddannelser och Uddannelses- og Forskningsministeriet (Danmark) och Kunnskapsdepartementet (Norge).

\begin{abstract}
Bakgrund
Huvudregeln i de nordiska länderna är att det är hemlandet som ska betala ut studiestöd. Således ska t.ex. en finsk medborgare som väljer att studera i Sverige få sitt studiestöd från Finland. Den finska lagstiftningen kräver dock att personen ska ha bott två av de senaste fem åren i hemlandet, dvs. Finland, för att få studiestöd. Motsvarande bosättningskrav finns även i den danska och norska lagstiftningen.

Problemen uppstår då en person först flyttar från sitt hemland till ett annat land för att arbeta, och sedan flyttar vidare till ett tredje land för att studera. I sådana fall har personen vanligtvis inte tjänat in rätt till studiestöd i sitt studieland, eftersom det kräver att personen bor i studielandet i två år. Personen har heller ingen rätt till studiestöd från sitt hemland om hon/han inte bott där under två av de senaste fem åren.
\end{abstract}

Konsekvensen blir att de unga människor som har utnyttjat den gemensamma nordiska arbetsmarknaden har sämre ekonomiska förutsättningar för att studera jämfört med de som stannat kvar i sitt hemland. De nationella regelverken är dessutom i strid med Helsingforsavtalet artikel 9 där det framgår att "ekonomiskt stöd från hemlandet bör kunna utgå, oavsett till vilket land studierna förläggas.”

\section{Vem påverkas}

Nordiska studerande som bott/arbetat utomlands innan de inleder sina studier.

\section{Ekonomiska konsekvenser}

Gränshindret som beskrivs här förutsätter att en person först flyttar från sitt hemland till ett annat land för att arbeta, och sedan flyttar vidare till ett tredje land för att studera på högskolenivå. Antalet som gör denna tredje flytt för att studera är begränsat, enligt uppskattningarna rör det sig endast om ett tiotal personer i Danmark respektive Finland. Studiestödet för en dansk student är DKK 65.140/år och studiestödet för en finsk student är EUR 4.531/år. Genom att inte betala ut studiestöd åt de personer som drabbas av hindret sparar den finska staten ca. EUR 50.000/år, danska staten å sin sida sparar ca. DKK 1.121.000/år. Närmare beräkningar finns nedan.

\section{Förslag till lösning}

Bosättningskravet i de nationella regelverken bör utgå. Alternativt sammanlägga perioder av sysselsättning i andra EU-länder och nordiska länder.

\section{Gränshinderrådets arbete med frågan}

I en finsk regeringsproposition kommer att föreslås att de nuvarande bestämmelserna om beviljande av studiestöd 
för studier utomlands ändras så att de inte längre är lika starkt grundade på personens boningsort utan stöd ska också kunna beviljas om en person annars på grund av sina levnadsförhållanden kan anses ha fasta band till Finland.

Det föreslås att $1 \S 4$ mom. i lagen om studiestöd, som gäller villkoren för studiestöd som beviljas utomlands, ändras så att enligt första punkten beviljas studiestöd en finsk medborgare som bedriver studier utomlands, om han eller hon i minst två år under de fem år som föregår inledandet av studierna har haft sin i lagen om hemkommun avsedda hemkommun i Finland. Huruvida villkoret om hemkommun enligt punkten är uppfyllt ska liksom för närvarande utredas med hjälp av villkoren i lagen om hemkommun.
Enligt andra punkten ska studiestöd för studier som bedrivs utomlands dessutom kunna beviljas en finsk medborgare som på grund av sina levnadsförhållanden annars har fasta band till Finland. Vid bedömningen av om banden är fasta ska man kunna beakta omständigheter i anslutning till personens familjeförhållanden, utkomst, yrkesmässiga och andra motsvarande levnadsförhållanden. Andra punkten ska tillämpas när en person inte kan anses ha haft hemkommun i Finland enligt lagen om hemkommun under den tid som avses i första punkten.

Som en följd av de två EU-domarna mot Nederländerna (juni 2012) respektive Danmark (februari 2013) så har Sverige infört nya regler utan bosättningskrav sedan december 2013.
På Åland, som har egen behörighet gällande studiestöd, ska en översyn av lagen just starta. Gränshinderrådet bör följa processen i Finland men även göra en kartläggning vilken effekt EU-domen har fått i Danmark.

\section{Kommentarer från berörda regeringar}

Ålands utbildningsminister: Rörligheten för studerande och yrkesutövare inom Norden och EU tillhör de grundläggande rättigheterna för medborgarna, därför är en förändring av bosättningskravet ett välkommet framsteg för mobiliteten.

Finland: En proposition med förslag till lagändring behandlas som bäst av riksdagen.

Läs mer i Gränshinderdatabasen, granshinder.norden.org, gränshinder nr: 14-036. 


\section{Beräkningar}

\section{Finland, befolkning 5451270}

Totalt antal finska medborgare som flyttat till ett nordiskt land och sedan flyttat vidare till ett tredje nordiskt land

Andel finländare i åldern 20-29, dvs. normal studieålder

Antal finska medborgare i åldern 20-29 år som flyttat till ett nordiskt land och sedan flyttat vidare till ett tredje nordiskt land

Andel finländare med lägre/högre högskoleutbildning

Antal finska medborgare i åldern 20-29 år som flyttat till ett nordiskt land och sedan flyttat vidare till ett tredje nordiskt land som förväntas ta en högskoleutbildning

Antal finländare som drabbas av gränshindret

\section{Danmark, befolkning 5639719}

Totalt antal danska medborgare som flyttat till ett nordiskt land och sedan flyttat vidare till ett tredje nordiskt land

Andel danskar i åldern 20-29, dvs. normal studieålder

Antal danska medborgare i åldern 20-29 år som flyttat till ett nordiskt land och sedan flyttat vidare till ett tredje nordiskt land

Andel danskar med lägre/högre högskoleutbildning

Antal danska medborgare i åldern 20-29 år som flyttat till ett nordiskt land och sedan flyttat vidare till ett tredje nordiskt land som förväntas ta en högskoleutbildning

Antal danskar som drabbas av gränshindret 


\title{
Godkännande av grönländska utbildningar
}

\author{
För den som tar en examen på Grönland och senare vill arbeta i ett annat \\ nordiskt land, finns det en risk att utbildningen inte är godkänd och därför \\ inte kan användas till något
}

Ett prioriterat gränshinder av Christian Wennecke.

Departementet för utbildning, kultur, kyrka och jämställdhet.

\section{Bakgrund}

För ett antal utbildningar krävs certifiering/legitimering för att få arbeta inom det yrke som utbildningen omfattar, så kallade reglerade yrken. Det gäller t.ex för vårdpersonal inom social och hälsa.

Det kan uppstå problem med att få anställning i ett annat nordiskt land, om det andra landet inte godkänner utbildningen. Det pågår redan ett arbete i nordisk regi kring detta hinder, där ambitionen är att få länderna att samarbeta kring implementeringen av det nya yrkeskvalifikationsdirektivet. Det har inspirerat till att även se på hindret ur ett grönländskt perspektiv.

För samhället blir det en vinst då utbildade personer arbetar i andra länder under en period för att få ny erfarenhet och nya kvalifikationer som de kan ta med sig tillbaka. Men hindret kan också redan vid valet av att utbilda sig på Grönland eller i ett annat land, bidra till att påverka personer att studera utomlands, om utbildningen i hemlandet inte ger samma möjligheter.

\section{Förslag till lösning}

Det finns en utredning av danska DAMVAD avseende yrkescertifiering/-legitimation i nordisk regi. Denna utredning följs av departementet för utbildning, kultur, kyrka och jämställdhet.

Det bör samtidigt inledas en intern utredning på Grönland, i syfte att bedöma om grönländska utbildningar godkänns i övriga nordiska länderna.

\section{Vem påverkas}

Alla med en utbildning som önskar använda den i ett annat nordiskt land.

\section{Gränshinderrådets arbete med frågan \\ Gränshinderrådet följer Nordiska ministerrådets arbete med att öka samarbetet mellan länderna gällande implementeringen av det nya yrkeskva- lifikationsdirektivet.}

\section{Kommentarer från relevanta regeringar}

På grund af valg og igangværende regeringsdannelse, har det ikke været muligt at indhente svar fra Naalakkersuisoq for Uddannelse, Kultur, Kirke og Ligestilling.

Läs mer i Gränshinderdatabasen, granshinder.norden.org, gränshinder nr: 14-128. 


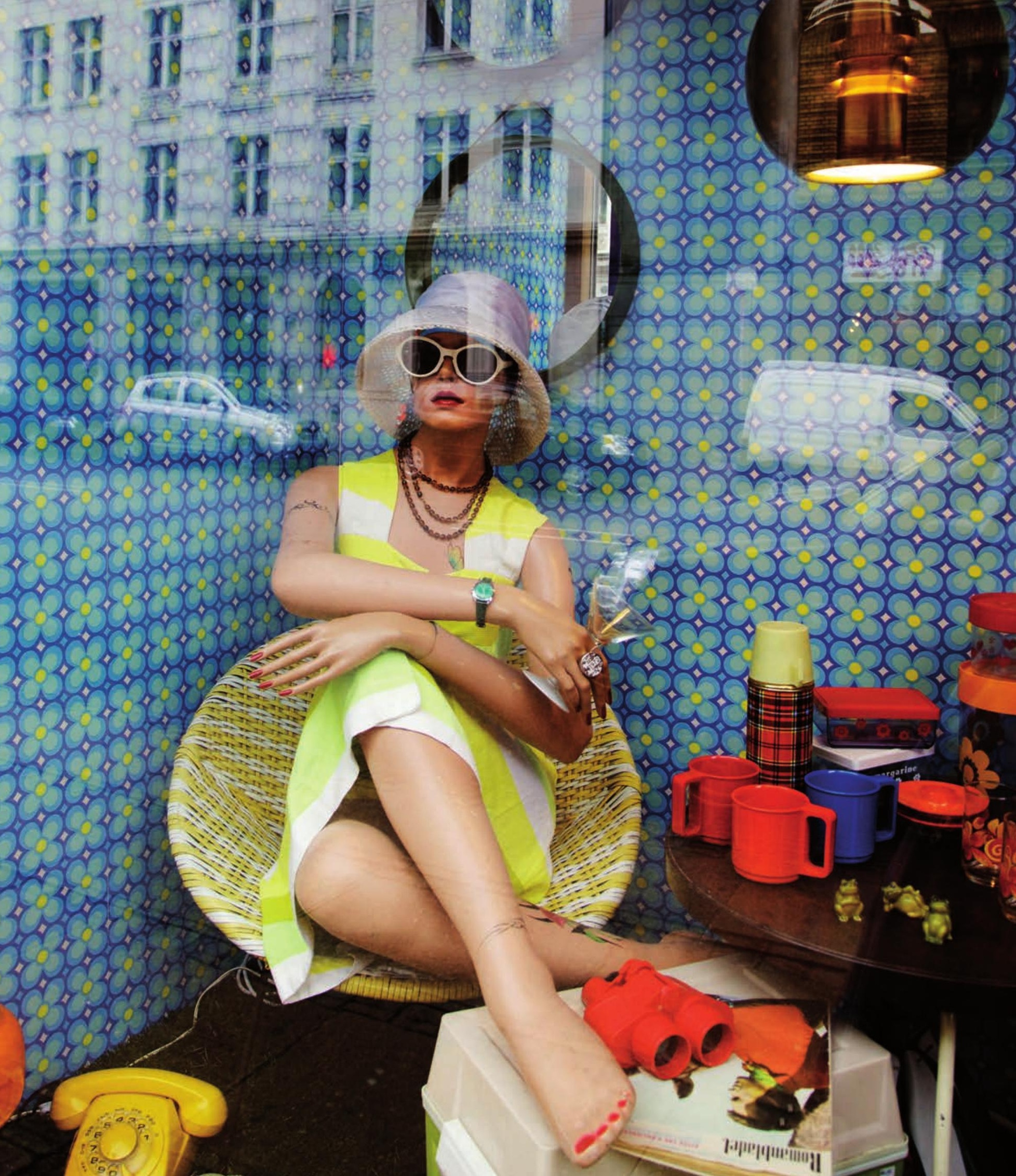


Hinder på socialförsäkringsområdet 


\title{
Sjukersättning patientresa mellan Norge och Finland/Sverige
}

\author{
En gränspendlare med bosättning i Finland eller Sverige med arbete i Norge är \\ socialförsäkrad och skattepliktig i Norge. Han eller hon får inte ersättning för \\ sina patientresor/behandlingsresor från hemmet i Finland/Sverige till sjukhuset \\ Norge till skillnad från sina arbetskollegor med bosättning och arbete Norge
}

Ett prioriterat gränshinder av Svein Ludvigsen, Norge och Sten Palmgren, Finland.

Hindret kan lösas av norska Helse- og omsorgsdeparetmentet.

\begin{abstract}
Bakgrund
Huvudregeln är att gränsgångare ska täckas av sjukförsäkringen i sitt arbetsland. Om en finsk medborgare som är bosatt i Finland arbetar i Norge, omfattas hon eller han av det norska sjukförsäkringssystemet och ska därmed vända sig till norska hälsovårdscentraler/sjukhus. Problemen uppstår då sådana gränsgångare hänvisas vidare till vidare utredning/behandling vid en annan hälsovårdscentral/ sjukhus i Norge. Då betalar inte norska Pasientreiser (en myndighet under Helseøkonomiforvaltningen, Helfo) ut ersättning för de resekostnader som gränsgångaren ådragit sig i samband med behandlingen.
\end{abstract}

Orsaken är att Pasientreiser kräver att alla behandlingsresor ska påbörjas och avslutas vid arbetsplatsen. För en person som är $100 \%$ sjukskriven kan det dock vara mycket svårt eller omöjligt att ta sig till arbetsplatsen från sitt hem på den finska sidan. Det innebär att personen själv måste betala kostnaderna för bil- och flygresor till behandlingsorten. För gränsgångare som bor och arbetar i norra Finland/Norge kan det då bli fråga om stora summor. Personen kan också ha svårt att ta sig till behandling/ rehabilitering i sitt bosättningsland (Finland) eftersom Pasientreiser/Helfo inte betalar resor inom Finland.

Motsvarande gäller för en gränspendlare som är bosatt i Sverige och arbetar i Norge.

\section{Vem påverkas}

Detta hinder påverkar samtliga medborgare som arbetar i Norge och bor i Finland eller Sverige, cirka 32300 pendlare.

\section{Ekonomiska konsekvenser}

Den totala resekostnaden är beräknad till EUR 462 för en finsk pendlare som är bosatt i Utsjoki, arbetar i Kirkenes och har behov av specialistvård i Oslo. Den motsvarande siffran för en person som pendlar från Stockholm till Oslo är EUR 153. Uppskattningsvis berörs ca. 210 gränspendlare från Finland och Sverige av hindret. Norska staten sparar i sin tur ca. EUR 77.000 på att inte lösa hindret. Närmare beräkningar finns nedan.

\section{Förslag till lösning}

Gränsgångare/nordiska arbetstagare får ersättning för reseutgifter i sitt hemland i förbindelse med läkarbesök och behandling enligt samma regler som norska och utländska arbetstagare bosatta i Norge.

\section{Gränshinderrådets arbete med frågan \\ Problemet har lyfts till NAV och HELFO, Gränshinderrådet har fått besked från Arbeids- og sosialdepartementet att saken överförts vidare till Helse- og omsorgsdeparetmentet den 15 oktober 2014. I december 2014 har Gränshin-}


derrådets norske medlem följa upp detta ärende med den norska samarbetsministern och berört departement, se svar från norska Helse- og omsorgsdepartementet nedan. Gränshindret kommer även att lyftas till Nordiska rådets norska delegation 3 februari 2015.

Saken har även tagits upp med Socialoch hälsovårdsministeriet i Finland.

\section{Kommentarer från berörda regeringar}

Social- och hälsovårdsministeriet i Finland konstaterar att saken måste lösas av de norska myndigheterna.

Helse- og omsorgsdepartementet i Norge meddelar att: En grensearbeider vil som hovedregel være forsikret i sitt arbeidsland, men ha helserettigheter både i sitt bostedsland og i arbeidslandet. En grensearbeider som er bosatt $i$ Finland, men som arbeider i Norge, vil derfor ha helserettigheter både i Finland på lik linje med landets øvrige innbyggere, samt i Norge som om han/hun var bosatt der. Det er helt opp til grensear- beideren selv å velge hvorvidt han/hun $ø$ nsker å henvende seg til helsevesenet i arbeidslandet Norge eller i bostedslandet Finland.

Alle utgifter i forbindelse med helsehjelp en grensearbeider har i sitt bostedsland, inkludert reiseutgifter i forbindelse med behandling/rehabilitering, skal gis av bostedslandet etter dette lands regelverk. En grensearbeider som er bosatt i Finland må kontakte finske trygdemyndigheter for refusjon reiseutgifter i forbindelse med behandling/rehabilitering gitt i Finland.

Problemet oppstår når grensearbeidere ønsker å motta helsehjelp i arbeidslandet (Norge), men starter reisen til den aktuelle behandlingen i bostedslandet ( Finland). I disse tilfeller betaler ikke Pasientreiser reiseutgiftene grensearbeideren pådrar seg $\mathrm{i}$ forbindelse med behandlingen. For at refusjon skal kunne gis må reisen være påbegynt i Norge, for eksempel ved arbeidsplassen. For en person som er $100 \%$ sykemeldt kan det være uaktuelt å påbegynne reisen fra annet sted enn bostedet. Dette innebæ- rer at personen selv må betale utgifter for bil- og flyreiser til behandlingsstedet. For grensearbeidere som bor nord i Finland/Norge kan dette bli snakk om store summer.

Helse- og omsorgsdepartmentet er i ferd med å revidere forskrift om rett till dekning av utgifter ved pasienters reise for undersøkelse eller behandling (syketransportforskriften). Forslag til ny forskrift har vært på høring, og en av høringsinstansene har meldt tilbake at det bør fremkomme i en ny forskrift hvilken instans som skal dekke utgifter til pasientreiser for konvensjonspasienter. Departementet vil på bakgrunn av dette innspillet samt henvendelsen fra Grensehinderrådet vurdere ulike problemstillinger knyttet til dekning av reiseutgifter for grensearbeidere. Hvorvidt en eventuell regulering av reiseutgifter for grensearbeidere krever endring i både lov og forskrift må utredes.

Läs mer i gränshinderdatabasen, granshinder.norden.org, gränshinder nr: 14-164. 


\section{Beräkningar}

Antal pendlare från Finland till Norge (2013)

4.124 personer

Kostnad för en finsk pendlare som bor i Utsjoki och i Oslo behöver specialistvård

- Transport från Ustjoki till Kirkenes flygfält

- Parkering vid Kirkenes flygfält

$43 €$

- Flyg tur/retur till Oslo

$8 €$

- Hotell i Oslo

$270 €$

- Transport tur/retur Oslo-Gardermoen

$100 €$

$41 €$

Total resekostnad för en person som drabbas av gränshindret

Kostnad för en finsk pendlare som bor i Stockholm och i Oslo behöver specialistvård

- Transport tur/retur från Arlanda flygfält till Stockholm

- Flyg tur/retur till Oslo

$43 €$

- Transport tur/retur Oslo-Gardermoen

$69 €$

- Transport tur/retur Oslo-Gardermoen

Total resekostnad för en person som drabbas av gränshindret 


\begin{tabular}{|lrr|}
\hline Antal gränspendlare till Norge & $\begin{array}{c}\text { Finland } \\
\text { Sverige }\end{array}$ \\
\hline $\begin{array}{l}\text { Andel av totala arbetsstyrkan som varit sjukanmäld mer än } \\
28 \text { dagar i sträck }\end{array}$ & 1,124 Personer & 28.141 personer \\
$\begin{array}{l}\text { Antal gränspendlare som varit sjukanmälda mer än } \\
28 \text { dagar i sträck }\end{array}$ & 71 personer & 786 personer \\
$\begin{array}{l}\text { Antagande: en fjärdedel av de som varit sjukanmälda i mer } \\
\text { än } 28 \text { dagar i sträck har behov av specialistvård }\end{array}$ & 18 personer \\
$\begin{array}{l}\text { Antagande: dessa personer har behov av specialistvård två } \\
\text { gånger under sjukdomsperioden }\end{array}$ & \\
\hline $\begin{array}{l}\text { Total resekostnad för en finsk gränspendlare (462€ x 2) } \\
\text { Total resekostnad för en svensk gränspendlare }(153 € \times 2) \\
\text { Besparing för den norska staten för finska respektive svenska pendlare }\end{array}$ & $16.632 €$ & $924 €$ \\
\hline Total besparing för den norska staten & & $306 €$ \\
\hline
\end{tabular}

Källor: Antal pendlare, Nordisk Pendlingskarta 2012 (från SE till NO) och norska Skattetaten 2014 (från Fl till NO). Hotell i Oslo, pris för trestjärnigt hotell i Oslo på Booking.com. Flygresor, SAS och Norwegian, priser för december 2014. Parkering Kirkenes Lufthavn, avinor.no. Bränslekostnader: Det antas att bilen kör $15 \mathrm{~km} / \mathrm{l}$ och att bensinen kostar EUR 1.449 per liter. Valutakurs: Norges Bank, Riksbanken samt Nationalbanken. 


\title{
Finska fyramånadersregeln
}

\author{
Finland införde inför utvidgningen av EU 2004 regler om bosättningsbaserade \\ förmåner som innebär att personer som inte är bosatta i Finland och vars \\ arbetsförhållande inte är minst fyra månader långt, inte heller är försäkrade \\ för vissa socialförsäkringsförmåner som de annars hade varit försäkrade för \\ genom sin bosättning Finland
}

Ett prioriterat gränshinder av Sten Palmgren, Finland. Även prioriterat av MR-S.

Hindret kan lösas av finska Social- och hälsovårdsministeriet.

\begin{abstract}
Bakgrund
När en person flyttar till Finland avgör Folkpensionsanstalten (FPA) om han eller hon ska omfattas av den finska bosättningsbaserade sociala tryggheten som FPA har hand om. Tryggheten omfattar följande förmåner: folkpension, barnbidrag, moderskapsunderstöd, bostadsbidrag, bostadsbidrag för pensionstagare, handikappförmåner, frontmannapension, garantipension och underhållsstöd. Även rätt till förmåner enligt sjukförsäkringslagen och lagen om Folkpensionsanstaltens rehabiliteringsförmåner och rehabiliteringspenningförmåner grundar sig på bosättning.
\end{abstract}

Om en person som kommer till Finland inte uppfyller villkoren för stadigvaran- de bosättning i Finland grundar sig rätten till FPA:s förmåner istället på arbete. Personer som omfattas av förordningarna 883/2004 och 1408/71 kan bli försäkrade och få rätt till FPA:s förmåner på basis av arbete om de under fyra månader arbetar minst 18 timmar i veckan och har en lön som motsvarar minst den lön som ska betalas enligt branschens kollektivavtal. Om det inte finns något kollektivavtal inom den aktuella branschen, ska lönen för arbetet vara minst 1154 euro i månaden (2014) vid heltidsarbete. Detta krav brukar kallas fyramånadersregeln.

Personen är visserligen försäkrad för arbetspension, arbetsskada och olycksfallsförsäkring och har rätt till offentlig hälsovård i Finland, men har inte rätt till exempelvis barnbidrag eller sjukförsäkring (sjukdagpenning, föräldrapenning). Fyramånadersregeln drabbar i hög grad nordiska säsongsarbetare inom turistnäringen i norra Finland.

\section{Vem påverkas}

Enligt SOLMU IV-rapporten från finska social- och hälsovårdsministeriet rör gränshindret ca. 1.500 personer. Säsongsarbetare är den persongrupp som är påverkas mest av gränshindret. Utbetalningarna av sociala trygghetsförmåner till en arbetstagare är beräknade till EUR 1.307 år, och EUR 27.078 år för en familj på fyra personer.

\section{Ekonomiska konsekvenser}

Utbetalningarna av de sociala trygghetsförmånerna som är aktuella i 


\section{Beräkningar}

Antagandet är att de 1500 som här nämns, är personer som under ett år har arbetat i Finland under max. fyra månader. Beräkningarna är gjorda utifrån antagandet att den genomsnittliga anställningstiden är tre månader.

Ökade utbetalningar av sociala trygghetsförmåner

Värdering av antalet berörda personer

Sociala trygghetsförmåner till en arbetstagare under tre månader

1.500 personer

$327 €$

Maksimal merudgift

detta fall uppgår till EUR 1.307/år. En arbetstagare som jobbar i Finland i endast tre månader, och således drabbas av fyramånadersregeln, går miste om förmåner till ett värde av EUR 327, dvs. en fjärdedel av totalbeloppet på EUR 1.307. Eftersom hindret antas beröra 1.500 personer, så sparar den finska staten ca. EUR 490.500 per år på att behålla fyramånadersregeln.

\section{Förslag till lösning}

Istället för fyramånadersregeln görs utbetalningen av sociala trygghetsförmåner baserat på en liknande regel för arbetsvillkor som finns i lagen om utkomstskydd för arbetslösa. Rätten till socialförsäkringsförmåner skulle i så fall träda in då personen arbetat minst 18 timmar per vecka och har en lön som motsvarar minimilönen enligt gällande kollektivavtal eller 1154 euro/månad om det inte finns något kollektivavtal. Alternativt kunde fyramånadersregeln göras om till en enmånadsregel.

\section{Gränshinderrådets arbete med frågan}

Saken har tagits upp med representanter för Folkpensionsanstalten (FPA) och social- och hälsovårdsministeriet våren 2014. En expertgrupp överlämnade ett betänkande på försommaren och ett seminarium ordnades. Några konkreta lösningsförslag har dock inte lagts fram. Gränshinderrådet skickade i april 2014 ett brev till dåvarande social- och hälsovårdsministern med ett önskemål om att saken förs vidare.
Nya diskussioner har förts hösten 2014. Frågan kräver ändring av den finska lagstiftningen och är beroende av arbetsmarknadsparternas godkännande. Saken är under beredning och social- och hälsovårdsministeriet anser att lagstiftningen bör ändras, men en proposition kommer inte att överlämnas före riksdagsvalen våren 2015.

\section{Kommentarer från berörda regeringar}

Finska Social- och hälsovårdsministeriet har meddelat att beredning av lagstiftning kan inledas tidigast våren 2015 efter riksdagsvalet.

Läs mer i Gränshinderdatabasen, granshinder.norden.org, gränshinder nr: 14-008. 


\title{
Problem vid flytt till Island med kvalifikationsperiod på 6 månader om E-104 blankett saknas
}

\author{
Island har en kvalifikationsperiod (karenstid) på 6 månaders innan en person \\ får rättigheter i enlighet med den isländska sjukförsäkringslagen
}

\section{Den person som flyttar till Island och har varit sjukförsäkrad i ett annat nor- diskt land, till exempel flyttar från Danmark till Island, kommer att vara fullt försäkrad på Island endast om han eller hon har omfattats av sjukförsäkring i det land han eller hon flyttar från}

Ett prioriterat gränshinder av Siv Friðleifsdóttir, Island.

Hindret kan lösas av det isländska Velfærdsministerium eller parlamentet.

\begin{abstract}
Bakgrund
Den som flyttar till Island blir enligt isländsk lag om sjukförsäkring, fullt försäkrad efter 6 månaders bosättning och folkbokföring.

En person kan dock omfattas av sjukförsäkringen om han eller hon kan bevisa, att han eller hon har omfattats av reglerna för sjukförsäkring i ett annat nordiskt land, eller i ett annat EU/EESland. Detta görs via blankett E-104 som används för att fastställa försäkrings-, bosättnings- och anställningsperioder $\mathrm{i}$ andra nordiska länder, eller i ett annat EU/ESS-land.
\end{abstract}

Länderna fastställer själva kriterier för när en person får tillgång till landets sjukförsäkring. När en person flyttar till Island ska han eller hon ha omfattats antingen av EU/EES-reglerna om samordning av socialförsäkring, eller av den nordiska konventionen om social trygghet, för att få tillgång till sjukförsäkringen omedelbart vid bosättning på Island.

\section{Vem påverkas}

Personer som flyttar till Island från ett nordiskt land utan att ha varit sjukförsäkrad, eller saknar nödvändiga dokument som visar att de har varit försäkrade i det land de kommer från.

\section{Förslag till lösning}

Myndigheterna på Island arbetar för att minimera den tid det tar för att inhämta nödvändiga handlingar från andra relevanta nordiska institutioner, och/eller förkorta kvalifikationsperioden.

\section{Gränshinderrådets arbete med frågan}

Under våren och sommaren har Gränshinderrådets isländska medlem undersökt vilken status detta hinder har på Island. 


\section{Nuvarande status}

- Enligt kontakter med de ämbetsmän som handlägger E-104 ärenden har utredningstiden blivit betydligt kortare än tidigare. Det innebär att problemen med långa väntetider inte uppstår i så stor utsträckning som tidigare.

\section{Kommentarer från berörda regeringar}

Island har ikke planer om å forandre kravet om 6 måneders bosætning på Island enligt national lov som nå er forutsetningen for å blive taget opp i det islandske sygesikringssystem. Ifölge den nordiske konvention om social sikring og EÖS aftalens regelværk tages der hensyn til tilbagelagte sygesikringsperioder i fraflytningslandet. Hvis den som flytter sin bosætning til Island har været dækket af den offentlige sygesikring i et andet nordiskt/EÖS/EU land i de sidste 6 måneder för tilflytningen til Islands tages denne periode i betraktning og vedkommende bliver dækket af den offentlige sygesikring i Island fra den tidspunkt han flytter sin bopæl til Island og bliver folkbokförd der.

De borgere som kommer fra de nordiske land til Island må henvende seg til de islandske sygesikringsmyndigheder og fremlegge dokumentation om tilbagelagte sygesikringsperioder i fraflytningslandet for at blive sygesikret i Islands fra tilflytningsdatoen. Hvis de medbringer ikke denne dokumentastion vil sygesikringsmyndighederne innhente den fra det andre nordiske land. Da den dokumentasjon foreligger bliver borgeren tatt opp i det islandske sygeforsikringssystem. Hvis vedkommende har i mellemtiden hatt utgifter på Island, som sygeforsikringen skulle ha dekket, blir de utgifter refunderet.

Vedkommende myndighedernes administration og praktisk gjennomförsel af national lovgivning og de internationale regler har man overveiet om og da hvordan det er mulig å gjöre administrationen mer fleksibel og smidig. I fölge opplysninger fra Islands Sygesikring er svartiden rundt 4-6 uger fra forespörrelse har vært sendt til sygesikringsmyndighederne i det andre nordiske land. Kan den ventetid ikke regnes unaturlig lang.

Läs mer i Gränshinderdatabasen, granshinder.norden.org, gränshinder nr: 14-176. 


\title{
Den norska faderskvoten
}

\author{
Män som arbetar i Norge, men som har en hustru/partner som inte \\ bor eller arbetar i Norge, har ingen självständig rätt till faderskvoten \\ (fedrekvoten) vid föräldraledighet med barn
}

Ett prioriterat gränshinder av Svein Ludvigsen, Norge samt MR-S.

Hindret kan lösas av norska Barne-likestillings- og inkluderingsdepartementet.

\section{Bakgrund}

Män som arbetar i Norge, men som har en hustru/partner som inte bor eller arbetar i Norge, har ingen självständig rätt till faderskvoten (fedrekvoten) vid föräldraledighet med barn. Rätten är härledd från moderns rätt.

Faderns självständiga rätt till ersättning vid föräldraledighet förutsätter att modern är förhindrad att sköta barnet på grund av sjukdom, heltidsarbete eller heltidsstudier.

\section{Förslag till lösning}

Rapporten "Gränshinder i Norden på social- och arbetsmarknadsområdet" (Nord 2012:002) föreslår att gränshindret skulle kunna lösas med tolkning av artikel 5.a i EU-förordning 883/2004. Denna bestämmelse förutsätter att den behöriga medlemsstaten beaktar liknande förmåner enligt en annan medlemsstats lagstiftning eller inkomster i en annan medlemsstatlagstiftning som om dessa hade erhållits i enligt den egna medlemsstatens lagstiftning eller i den egna medlemsstaten.

På så sätt kunde män som arbetar i Norge härleda sin rätt till faderskvoten från sin hustru/partner oberoende av var hon arbetat. Moderns rätt till föräldrapenning i ett annat nordiskt land borde nämligen ha likvärdig betydelse som moderns rätt till föräldrapenning i Norge enligt norsk lagstiftning.

\section{Vem påverkas}

Detta hinder påverkar par där fadern arbetar i Norge medan modern arbetar i ett annat nordiskt land före födseln.

\section{Ekonomiska konsekvenser då detta hinder löses}

Man estimerar att cirka 850 av de manliga gränspendlarna till Norge årligen blir fäder. Maximalt skulle Norge därmed få en tilläggskostnad på 86,3 miljoner NOK genom att lösa detta gränshinder.
Närmare beräkningar finns nedan.

\section{Gränshinderrådets arbete med frågan}

Hindret har tagits upp skriftligt genom brev till norska Barne-likestillings- og inkluderingsdepartementet, svar från dem inväntas. Under fjärde kvartalet 2014 kommer ärendet att följas upp genom att be om ett möte med departementet. I december 2014 har Gränshinderrådets norske medlem följa upp detta ärende med den norska samarbetsministern och berört departement, se svar från norska barne-, likestillingsog inkluderingsdepartementet nedan. Gränshindret kommer även att lyftas till Nordiska rådets norska delegation 3 februari 2015.

\section{Kommentarer från berörda regeringar}

Norska barne-, likestillings- og inkluderingsdepartementet (BLD) meddelar att: BLD er kjent med at den norske fedrekvoten er vurdert av Grensehinderrå- 
det som et grensehinder. Departementet har også vurdert denne saken flere ganger tidligere.

\section{Departementets vurdering er at det} ikke er mulig å lage en egen særnordisk ordning for de fedrene som denne saken gjelder, uten at det kommer i konflikt med EU/EøS-regelverket. Rett til fedrekvote for alle fedre med opptjening i Norge, der mor har opptjening i et annet EØS-land, vil antagelig bli svært kostbart. Det vil også bli krevende å administrere for NAV.

Også en særnordisk løsning ville medføre en betydelig kostnad. Grensehinderrådet har anslått at rett til fedrekvote for de nordiske fedrene som har opptjening i Norge, og der mor har opptjening i et annet nordisk land, vil innebære en merkostnad på maksimalt 75,5 mill. kroner. I anslaget er det tatt høyde for at det gjelder om lag 755 fedre, og at maksimal utbetaling av fedrekvote i ti uker er på om lag 100000 kroner. En endring som medfører så store økonomiske konsekvenser kan ikke dekkes innenfor BLDs budsjettrammer; den ville måtte vurderes av regjeringen som en budsjettsak.

BLD vil også understreke at regelverket gjelder tilsvarende når begge foreldrene bor i Norge. Fedre som har barn med en mor i Norge, og der moren mangler opptjening til foreldrepenger, har heller ikke rett til fedrekvote til tross for egen opptjening. Fedrene kan likevel ta ut foreldrepenger på eget opptjeningsgrunnlag, men bare dersom mor går ut i aktivitet (jobb, studier mv.) eller hun er for syk til å ta seg av barnet. At det er krav til mors aktivitet når far skal ta ut foreldrepenger (som ikke er fedrekvote) er begrunnet med at man ikke ønsker å betale ut foreldrepenger til far hvis mor likevel er hjemme og kan ta seg av barnet. Aktivitetskravet til mor for fars uttak av foreldrepenger gjelder for alle tilfeller der mor ikke har opptjent rett til foreldrepenger i Norge. BLD vurderer at det ikke er tilstrekkelig god grunn til å gi fedre som har barn med mødre i andre land bedre rettigheter enn de som har barn med mødre i Norge.

Läs mer i Gränshinderdatabasen, granshinder.norden.org, gränshinder nr: 14-126. 


\section{Beräkningar}

Man estimerar att 850 av de manliga gränspendlarna till Norge årligen blir fäder. Maximalt skulle Norge därmed få en tilläggskostnad på 83,6 miljoner NOK genom att lösa detta gränshinder.

Huvudparten av de nyblivna fäderna är mellan 25 och 39 år. Omkring 9.000 män i åldern 25-39 år pendlar till Norge från Danmark, Finland och Sverige. Det senaste kontrollerade antalet från Danmark och Sverige är från år 2009, det senaste antalet från Finland från år 2013. Talet för antalet finska gränspendlare är baserat på upplysningar från norska Skatteetaten och skiljer sig därför metodmässigt från beräkningen av gränspendlare till Sverige från Norge och Danmark. Statistiken gällande dessa sistnämnda pendlare baseras på upplysningar från nationell registerbaserad arbetsmarknadstatistik som publicerats i StatNord.

Utgående från antagandet att 80\% av alla nyfödda har en far som är mellan 25-39 år, kan man beräkna att omkring 850 manliga pendlare till Norge årligen förlorar rätten till faderskapsersättning p.g.a. att de bor i ett annat nordiskt land.

\begin{tabular}{|c|c|c|c|c|c|}
\hline 2013 & Nyfödda & Män 25-39 år & $\begin{array}{l}\text { Andel 25-39 åriga } \\
\text { män, som blir pappor }\end{array}$ & $\begin{array}{l}\text { Antal 25-39-åriga män } \\
\text { som pendlar till Norge }\end{array}$ & $\begin{array}{l}\text { Manliga pendlare till } \\
\text { Norge som blir fäder }\end{array}$ \\
\hline Sverige & 113593 & 939601 & $9,70 \%$ & 6883 & 670 \\
\hline Danmark & 55873 & 513564 & $8,70 \%$ & 624 & 50 \\
\hline \multirow[t]{3}{*}{ Finland } & 58134 & 529750 & $8,80 \%$ & 1442 & 126 \\
\hline & & & & & 846 \\
\hline & & & & & NOK \\
\hline \multicolumn{4}{|c|}{ Maximalt belopp för föräldrapenning } & & 530.220 \\
\hline \multicolumn{4}{|c|}{ Faderskvoten (10 veckor) } & & 101.965 \\
\hline \multicolumn{4}{|c|}{ Manliga pendlere til Norge, som blir fäder } & & 846 \\
\hline \multicolumn{5}{|c|}{ Max. udgift til faderskvoten (10 veckor) } & 86.262 .715 \\
\hline
\end{tabular}

Det maximala årliga beloppet som kan utbetalas som föräldraersättning är 530.220 NOK. Eftersom faderns andel av föräldraledigheten är 10 veckor, kommer den maximala utgiften för den enskilde nyblivne fadern att vara 101.965 NOK. Den totala utgiften för samtliga gränspendlare från Danmark, Sverige och Finland uppgår till 86,3 miljoner NOK. 


\title{
Flytt för institutionaliserade personer
}

\author{
Enligt den nordiska konventionen om socialt bistånd och sociala tjänster \\ ska de ansvariga myndigheterna samarbeta för att göra det möjligt för \\ äldre eller institutionaliserade personer att flytta till det land där de har \\ starkast personlig anknytning. Detta fungerar inte i praktiken på grund \\ av oklarheter kring betalning och ansvar
}

Ett prioriterat gränshinder av Ole Stavad, Danmark.

Hindret ingår i avtalet mellan danska Folketinget och danska regeringen.

Hindret kan lösas av socialministerierna och handläggande myndigheter i de nordiska länderna.

\begin{abstract}
Bakgrund
Möjligheten för personer som behöver långvarig vård och behandling att flytta från ett nordiskt land till ett annat grundar sig på artikel 9 i den nordiska konventionen om socialt bistånd och sociala tjänster från 1994.

I alla nordiska länder är det kommunerna som är ansvariga för denna vård.

Konventionen ger kommunen befogenhet och skyldighet att medverka till flyttningen till ett annat nordiskt land och eventuellt träffa överenskommelse om fördelning av kostnaderna för vård och behandling i de båda länderna. Det finns dock inga sådana direkta regler gällande fördelningen av kostnaderna,
\end{abstract}

i praktiken uppstår därför problem för den enskilde eftersom de ansvariga myndigheterna i ut- och inflyttningsländerna är osäkra på vem som ska stå för flytt- och vårdkostnader.

\section{Vem påverkas}

Hindret påverkar antagligen inte så många, men det har stora konsekvenser för enskilda personer som drabbas.

\section{Förslag till lösning}

Länderna arbetar för att revisionen av den Nordiska konventionen om socialt bistånd och sociala tjänster ska innehålla tydliga regler om ansvarsfördelning och eventuell fördelning av kostnader mellan ländernas myndigheter.

Samtidigt bör man utveckla ett bättre informationssystem mellan kommunerna i de nordiska länderna som medför att kommunerna känner till artikel 9 i den nordiska konventionen.

\section{Gränshinderrådets arbete med frågan}

Under våren har Gränshinderrådet undersökt vilken status detta hinder har i Danmark.

- Gränshinderrådets danska medlem har hållit möte med ministern för barn, jämställdhet, integration och sociala förhållanden den 26 maj. Ministern meddelade att det kommer att tas konkreta initiativ för att lösa gränshindret. 


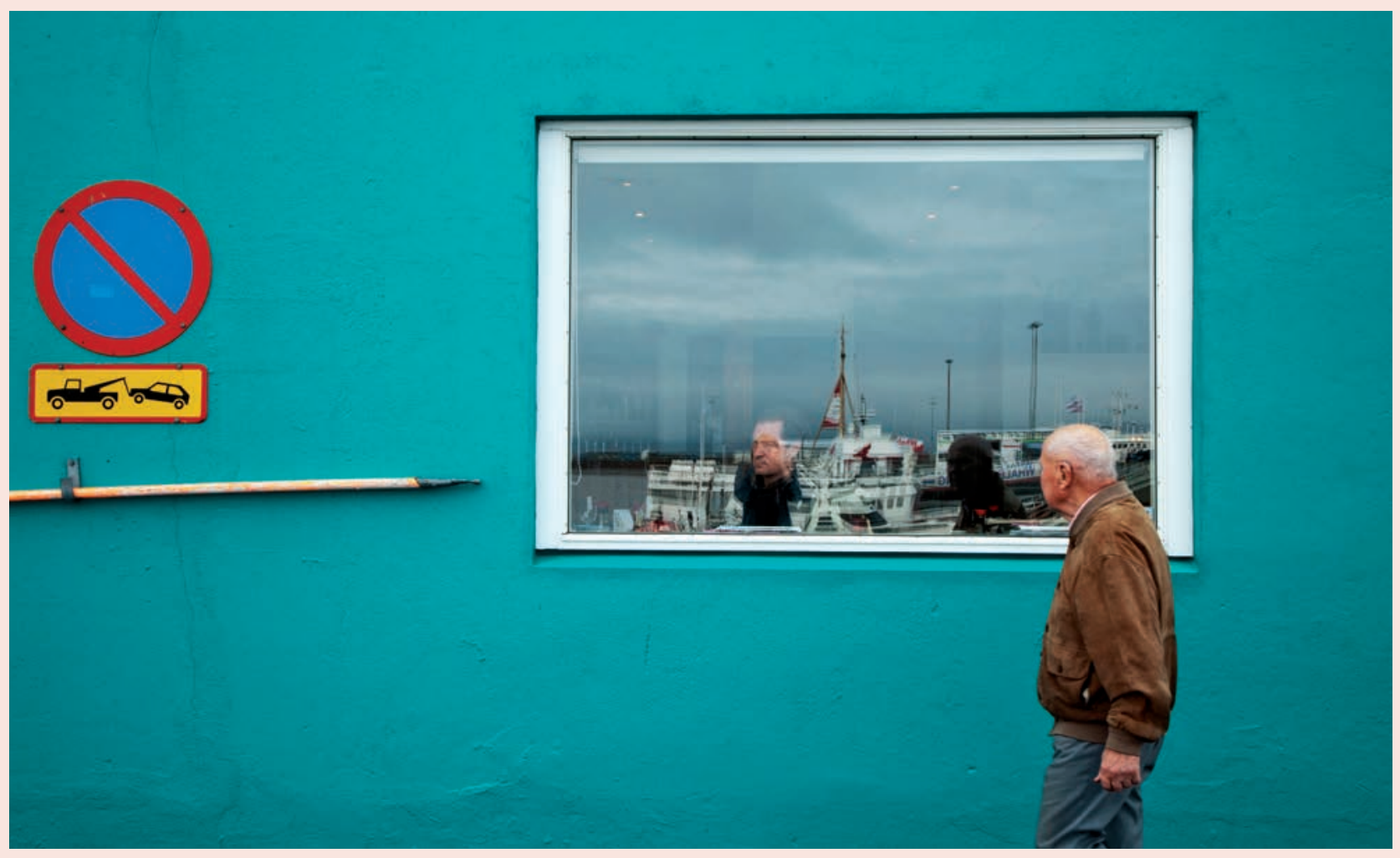

\section{Kommentarer från berörda regeringar}

Ministeriet for Børn, Ligestilling, Integration og Sociale Forhold meddelar att: Der er taget initiativ til, at der på fælles nordisk plan kan lægges op til klarere vejledning til relevante myndigheder om myndighedernes samarbejde i forbindelse med anmodning fra plejekrævende borgere om flytning til et andet nordisk land.
Med henblik på at afklare, hvorvidt der er behov for en revision af Den Nordiske Konvention om Social Bistand og Sociale Tjenester, har arbejdsgruppen i foråret 2013 igangsat en analyse, hvor Bistandskonventionens bestemmelser ses i sammenhæng med EU og international ret samt de nordiske landes nationale lovgivning. Arbejdet hermed forestås af en ekstern ekspert.
Arbejdet med analysen blev drøftet på møde i arbejdsgruppen den 11. september 2014, og efterfølgende fremsendes analysen til Nordisk Ministerråd i januar 2015. På baggrund af denne analyse træffes den endelige afgørelse om revision af konventionen, der vil kunne iværksættes i 1. halvår i 2015.

Läs mer i gränshinderdatabasen, granshinder.norden.org, gränshinder nr: 14-104. 


\title{
Studerandes socialförsäkring i ett annat nordiskt land
}

\author{
När det gäller rätten för studerande från nordiska länder att bli social- \\ försäkrade i ett annat nordiskt land så finns det oklarheter gällande \\ vilket lands lagstiftning som är tillämplig
}

Ett prioriterat gränshinder av Ole Stavad, Danmark samt MR-S.

Hindret finns även i avtalet mellan det danska Folketinget och regeringen om borttaganade av nordiska gränshinder.

\begin{abstract}
Bakgrund
Förordning 883/2004 om koordinering av samordning av de sociala trygghetssystemen trädde i kraft den 1 maj 2010 för EU-länderna. I Norge och Island gäller samma samordningsregler mellan de nordiska länderna. Enligt förordning 883/2004 tillämpas bosättningslandets lagstiftning på icke-förvärvsaktiva personer, därmed även studerande, som ska omfattas av det landets lagstiftning där de är bosatta. Med bosättning menas enligt förordningen stadigvarande bosättning. Bosättning avgörs primärt enligt nationell lagstiftning.
\end{abstract}

\footnotetext{
Tillämpningsförordning 987/2009 anger vissa kriterier för fastställande av bosättningsort om flera medlemsstaters institutioner har skilda uppfattningar om var en person är bosatt. Folkbokföringen är inte avgörande för fastställande av bosättningsland. Det ska bedömas var personen har sina hu-
}

vudsakliga intressen. Eftersom många sociala tjänster i de nordiska länderna beror på bosättning är denna bedömning av stor betydelse för icke förvärvsaktiva personer och studenter som flyttar mellan de nordiska länderna.

De nordiska länderna har inte heller likadana nationella regler om studenters socialförsäkring eller om hur länge de kan fortsätta att vara försäkrade $i$ landet de kommer från. Även om samma samordningsregler gäller mellan alla de nordiska länderna så görs bedömningen av vem som anses vara bosatt i landet i varje enskilt fall. Det gör systemet mer komplicerat än det är i dag, och det kommer att ta längre tid att få ett beslut om bosättning än att göra en ändring av folkbokföringen. Det kan också förekomma att vissa studenter anses som bosatta i inflyttningslandet, medan andra inte anses vara det. Socialförsäkringsskyddet för dem som inte anses bosatta i studielandet beror då på de nationella reglerna i landet som studenten kommer från.

Problemet kan då uppkomma att det land som studenten kommer från anser att han eller hon inte längre är försäkrad i det landet, samtidigt som landet som studenten flyttar till anser att hon eller han inte är bosatt eller försäkrad där.

\section{Förslag till lösning}

Länderna försöker hitta en gemensam uppsättning kriterier för när studerande omfattas av ett lands lagar, för att säkerställa att inga studerande som flyttar mellan de nordiska länderna riskerar osäkerhet om vilket lands lagstiftning som ska tillämpas.

\section{Vem påverkas}

Problemet påverkar troligen ett mindre antal studerande som rör sig över de nordiska gränserna. 


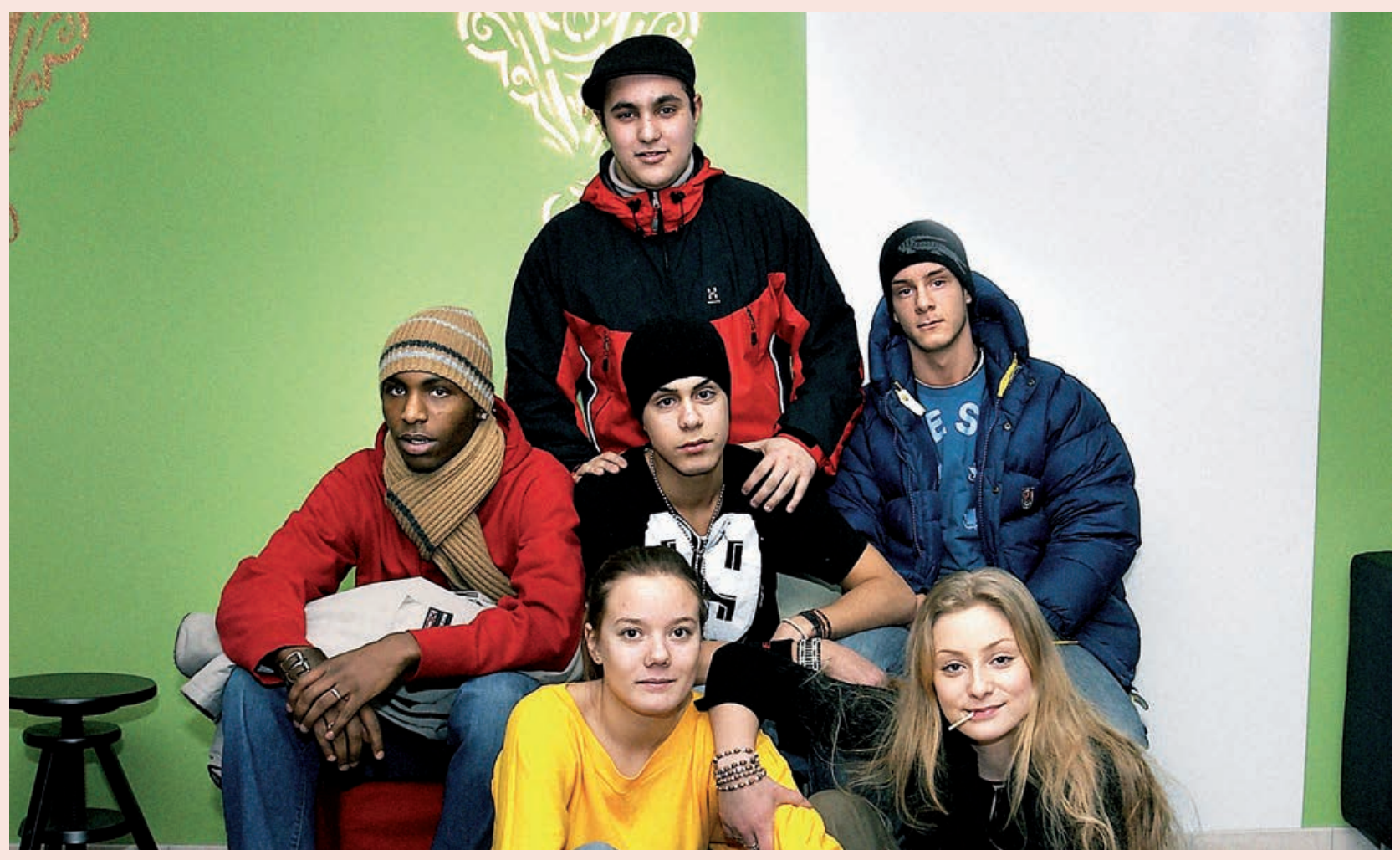

\section{Gränshinderrådets arbete med frågan}

Under våren har Gränshinderrådet undersökt vilken status detta hinder har i Danmark.

\section{Nuvarande status}

- Gränshinderrådets danska medlem har hållit möte med ministern för barn, jämställdhet, integration och sociala förhållanden den 26 maj. Ministern meddelade att det kommer att tas konkreta initiativ för att läsa gränshindret.

\section{Kommentarer från berörda regeringar}

Ministeriet for Børn, Ligestilling, Integration og Sociale Forhold meddelar att: problemstillingen er blevet rejst i Den Nordiske Socialforsikringsgruppe. Den Administrative Kommission har udarbejdet en supplerende guide om lovvalg, som også indeholder kriterier for fastlæggelse af lovvalg for studerende.

Det blev på seneste møde i Den Nordiske Socialforsikringsgruppe den 12. september 2014 besluttet, at sagen skal behandles i den nordiske forbindelsesorgangruppe med henblik på at afklare, om denne guide er dækkende til tydeliggørelse af de gældende landes lovgivning.

Läs mer om i gränshinderdatabasen, granshinder.norden,org, gränshinder nr: 14-100. 


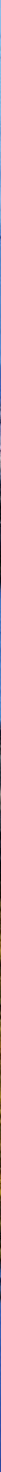


Hinder på
skatteområdet

Hinder på
skatteområdet

s.

(n) 


\section{Frågor om dubbelbeskattningsavtalet $\mathrm{i}$ förhållande till studiestöd}

\section{Olika regler gällande beskattningen av studiestöd kan leda till både för- och nack- delar för personer beroende på var personen är bosatt och var studierna bedrivs}

Ett prioriterat gränshinder av Ole Stavad, Danmark.

Hindret ingår i avtalet mellan det danska Folketinget och regeringen.

Hindret kan lösas av det danska skatteministeriet och svenska finansdepartementet.

\section{Bakgrund}

Det danska studiestödet anses vara beskattningsbar inkomst till skillnad från den svenska motsvarigheten. Med andra ord är danskt studiestöd beräknat som ett bruttobelopp medan det svenska är ett nettobelopp.

Skillnaderna i beskattningen medför, att danskt studiestöd till en student vid en dansk utbildningsinstitution som är bosatt i Sverige inte beskattas i varken Danmark eller Sverige. Studenten får därmed ett högre belopp än medstudenterna som är bosatta i Danmark.

Om det istället rör sig om svenskt studiestöd till en student vid en svensk utbildningsinstitution som är bosatt i Danmark så kommer studiestödet att beskattas i Danmark. Studenten får därmed ett lägre belopp än medstudenterna som är bosatta i Sverige.

Gränshindret kan rimligtvis uppstå i alla regioner där det finns skillnader mellan beskattningen av studiestöd, men torde främst aktualiseras i Öresundsregionen.

\section{Vem påverkas}

Detta hinder påverkar främst personer $\mathrm{i}$ Danmark och Sverige.

Problemet påverkar troligen ett större antal studerande, som rör sig över de nordiska gränserna.

\section{Förslag till lösning}

Länderna förhandlar och genomför en lösning, så att de studerande inte upplever stora negativa svängningar i sina ekonomier genom att flytta till ett annat land.

\section{Gränshinderrådets arbete med frågan}

Under våren har Gränshinderrådet undersökt vilken status detta hinder har i Danmark.

Nuvarande status

- Gränshinderrådets danska medlem har hållit möte med den danska skatteministern Morten Østergaard den 26 maj. Han meddelade att det kommer att tas konkreta initiativ för att lösa ett antal gränshinder inom skatteområdet.

\section{Kommentarer från berörda regeringar}

Hvad angår Skatteministeriets to punkter på statuslisten - beskatning af uddannelsesstøtte og beskatning af kapitalpensioner - kan ministeriet til orientering oplyse, at der blandt de nordiske lande synes at være en positiv holdning over for en løsning af de pågældende spørgsmål. Det er dog samtidig indtrykket, at man ikke anser disse spørgsmål for at være af en sådan tyngde, at de i sig selv kan "bære" en protokol til ændring af den nordiske dobbeltbeskatningsoverenskomst. Dette hænger formentlig sammen med, at gennemførelse af en ændringsprotokol er en omstændelig procedure, der bl.a. involverer lovgivning. Status er således, at de to spørgsmål medtages, når der bliver lejlighed til mere substantielle ændringer af den nordiske dobbeltbeskatningsoverenskomst.

Läs mer i gränshinderdatabasen, granshinder.norden.org, gränshinder nr: 14-156. 


\title{
Dubbelbeskattning Grönland och Sverige/Finland
}

\author{
Grönland ingår inte i det nordiska avtalet om dubbelbeskattning. Det måste \\ därför för varje land finnas ett avtal om undvikande av dubbelbeskattning
}

Ett prioriterat gränshinder av Christian Wennecke, Grönland.

Hindret kan lösas av Naalakkersuisut/Inatsisartut och Finansdepartementet.

\begin{abstract}
Bakgrund
Det finns för närvarande inga skatteavtal för undvikande av dubbelbeskattning mellan Grönland, Finland och Sverige, i likhet med dem som finns med t.ex. Danmark och Norge. Detta leder till osäkerhet om beskattning av inkomster för personer som flyttar mellan länderna och det minskar incitamentet att flytta för att arbeta, studera, bosätta sig eller liknande.
\end{abstract}

Departementet för finans och inrikesfrågor samt Skattestyrelsen på Grönland är ansvariga för området.

\section{Vem påverkas}

Hindret påverkar Finland, Sverige och Grönland. Antalet personer som drabbas är sannolikt få.

\section{Ekonomiska konsekvenser}

Om de skattemässiga konsekvenserna av att flytta mellan Grönland, Finland och Sverige blir lösta kommer det troligen att öka viljan att röra sig mellan de länderna i positiv riktning.

\section{Förslag till lösning}

Två lösningar har föreslagits:

a) Bilaterala avtal om dubbelbeskattning med Sverige och Finland, i likhet med de avtal som finns med övriga nordiska länder.

b) På Gränshinderrådets kick-off diskuterade rådet hindret och frågan om varför Grönland inte är med i det gemensamma nordiska avtalet om dubbelbeskattning. Avtalet är under revision och Grönland föreslås överväga om anslutning till avtalet.

\section{Gränshinderrådets arbete med frågan}

Under våren och sommaren har Gränshinderrådet undersökt vilken status detta hinder har i Grönland.

\section{Nuvarande status}

- Kontakter har tagits med Skattestyrelsen som anser att avsaknaden av ett dubbelbeskattningsavtal mellan Grönland och de övriga nordiska länderna inte är ett problem.

\section{Kommentarer från berörda regeringar}

På grund af valg og igangværende regeringsdannelse, har det ikke været muligt at indhente svar fra Naalakkersuisut for Finanser.

Läs mer i Gränshinderdatabasen, granshinder.norden.org, gränshinder nr: 14-177. 


\title{
Rutiner för skatteinbetalning för äkta gränsgångare
}

\author{
Personer och arbetsgivare som bor och verkar i de gränskommuner i Sverige \\ och Finland som gränsar mot Norge upplever problem med skatteinbetalningar
}

Ett prioriterat gränshinder av Svein Ludvigsen, Norge.

Hindret kan lösas av norska finansdepartementet, svenska finansdepartementet och finska finansministeriet.

\begin{abstract}
Bakgrund
Personer som bor i en gränskommun, arbetar i en av det andra landets gränskommuner och omfattas av gränsgångaravtalet ska skatta till sin boendekommun. Dessa personer ska själva sköta sina skatteinbetalningar på tidigare lämnade uppgifter till Skatteförvaltningen. För den person som har en ojämn inkomst blir det synnerligen komplicerat att veta hur mycket man ska betala in i förväg.
\end{abstract}

En person som är en gränsgångare enligt skatteavtalet betalar en socialförsäkringsavgift (trygdeavgift) på 8,2 $\%$. Denna räknas inte som en skatt utan som en avgift vilket genererar ett avdrag på den finska/svenska deklarationen. Frågan är om inte detta är en dubbelbeskattning som borde ge en skatteavräkning i stället.

En arbetsgivare kan även den bli drabbad av extra administrativt arbete. Om personen ovan även arbetar i en icke gränskommun erläggs skatten för denna inkomst till Norge. Arbetsgivaren måste då upprätta två lönespecifikationer.

\section{Vem påverkas}

Enligt StatNords pendlingsstatistik från 2009 pendlar 1.144 personer från en svensk gränskommun till en norsk gränskommun.

\section{Ekonomiska konsekvenser}

En person som är bosatt i Strömstad i Sverige och arbetar heltid i grannkommunen Halden i Norge, med en månadslön på NOK 45.000 vilket motsvarar en årsinkomst på SEK 606.700, förlorar ca. NOK 24.000 per år eftersom socialförsäkringsavgiften (trygdeavgiften) avräknas mot bruttoinkomsten och inte mot skatten. Närmare beräkningar finns nedan.

\section{Förslag till lösning}

- Ett förslag kan vara att samtliga gränspendlare, oavsett om de bor och arbetar mellan två gränskommuner eller inte, blir både socialförsäkrade (betalar trygdeavgift) och skattskyldiga i antingen i bosättningslandet eller i arbetslandet.

- Ett annat förslag är att personen är fortsatt skattpliktig i Sverige och att socialförsäkringstillhörigheten tillhör Norge, men att personen inte inbetalar socialförsäkringsavgiften (trygdeavgiften).

- Ett tredje förslag är socialförsäkringsavgiften (trygdeavgiften) dras av från den svenska beräknade skatten, se närmare beräkningar nedan.

\section{Gränshinderrådets arbete med frågan}

Detta hinder har skriftligt genom brev lyfts till det norska finansdepartementet och svar väntas. Under fjärde kvartalet 2014 kommer ärendet att följas upp genom ett möte med departementet. I december 2014 har Gränshinderrådets norske medlem följer upp detta ärende med den norska samarbetsministern 
och berört departement, se svar från norska Finansdepartementet nedan. Gränshindret kommer även att lyftas till Nordiska rådets norska delegation 3 februari 2015.

\section{Kommentarer från berörda ministrar}

Norska Finansdepartementet meddelar att: Grensehinderrådet tar opp flere problemstillinger knyttet til skatteinnbetalingen for dem som er grensegjengere etter bestemmelsene i den nordiske skatteavtalen. Dette er bare en av mange praktisk/administrative vanskeligheter som oppstår for denne skattytergruppen og som gjennom en årrekke har skapt problemer for arbeidstakere, arbeidsgivere og ikke minst for landenes skattemyndigheter.

Slik situasjonen er i dag er det grensegjengerbestemmelsene i seg selv som representerer det egentlige grensehinderet. Det som var ment å være en forenkling for 30 år siden, er langt på vei blitt en hindring idag. Det er mye vanskeligere for alle involverte parter å håndtere beskatningen av grensegjengere enn det er å håndtere beskatningen av andre grenseoverskridende arbeidstakere i Norden. Norge er derfor av den oppfatning at bestemmelsene om grensegjengere bør tas ut av den nordiske skatteavtalen. De aller fleste praktiske og administrative problemene knyttet til denne skattytergruppen ville forsvinne av seg selv dersom en hadde skattlagt grensegjengere slik som alle andre arbeidstakere innenfor Norden. Både for arbeidstakerne selv, arbeidsgiverne og de respektive lands skattemyndigheter ville en opphevelse av disse reglene føre til en enklere og mer strømlinjeformet hverdag med hensyn til inntektsrapportering, skatteinnbetaling og ligning.

Norge har riktignok etablert nye rutiner for grensegjengere som arbeider i Norge (særskilt skattekort, egen selvangivelse for grensegjengere, trekk- og innbeta- ling av trygdeavgift til skattemyndighetene i stedet for trygdemyndighetene osv.). De nye rutinene bidrar til å lette situasjonen for ekte grensegjengerne for så vidt gjelder deres forpliktelser overfor norske myndigheter. De berører imidlertid ikke de problemene en grensegjenger har dersom han mottar andre ytelser enn bare lønnsinntekt eller de problemene han får i forbindelse med beskatningen i sitt bostedsland.

Det bygger på en feilaktig forståelse av hvordan grensegjengerreglene er å forstå når Grensehinderrådet hevder at en arbeidsgiver får ekstra administrativt arbeid hvis en grensegjenger arbeider både i en grensekommune og i en annen kommune. En slik arbeidstaker anses ikke som grensegjenger for den inntekten som opptjenes i grensekommunen. I et slikt tilfelle vil arbeidstakeren bli skattlagt på vanlig måte i arbeidslandet for hele sin lønnsinntekt uavhengig av hvilken kommune den er opptjent i. Arbeidsgiver skal derfor 
ikke foreta noen spesifikasjon av av lønnsinntekten pr kommune, men skal rapportere alt som én inntekt.

I brevet fra Grensehinderrådet er det reist spørsmål om det ikke utgjør en dobbeltbeskatning at man kun får et inntektsfradrag i bostedsstaten for betalt trygdeavgift i arbeidsstaten istedenfor at det gis et fradrag i skatten for denne avgiften.

Dobbeltbeskatning innebærer at en inntekt er undergitt inntektsbeskatning i to land. Pr i dag blir en grensegjenger bare inntektsbeskattet i bostedsstaten sin, så det foreligger ingen dobbeltbeskatning i disse tilfellene.

Det kan imidlertid tenkes at det fore- ligger dobbelt betaling av trygdeavgift. Dette vil særlig kunne være tilfelle hvor bostedsstaten inkluderer en slik avgift i inntektsskatten og den ikke lar seg særskilt skille ut som en egen prosentssats eller sum. Vi viser til brevet fra Grensehinderrådet hvor det opplyses at Sverige og Finland løser dette ved å gi inntektsfradrag for den norske trygdeavgiften, men uten at dette fullt ut kompenserer for den doble betalingen av trygdeavgift. Problemstillinger knyttet til (dobbelt) betaling av trygdeavgift hører ikke under Finansdepartementets fagområde. Spørsmål om dette må rettes til Arbeids- og Sosialdepartementet.
Norske grensegjengere kan ikke få fradrag i norsk inntektsskatt for sosiale avgifter betalt i Sverige eller Finland. Det skyldes at slike avgifter ikke er omfattet av den nordiske skatteavtalen og heller ikke anses som inntektsskatter etter norske interne regler. Fradrag for norsk trygdeavgift i den svenske/ finske inntektsskatten må eventuelt tas opp med henholdvis svenske og finske myndigheter.

Läs mer i gränshinderdatabasen, granshinder.norden.org, gränshinder nr: 14-056.

\section{Beräkningar}

\begin{tabular}{|lrr|}
\hline & & $\begin{array}{r}\text { Avräkning för } \\
\text { Trygdeavgift efter skatt }\end{array}$ \\
Bruttoinkomst/lön & Dagsläge & 606.700 SEK \\
Avdrag & 606.700 SEK & 13.100 SEK \\
Grundavdrag & 49.750 SEK & 593.600 SEK \\
Förvärvsinkomst & 13.100 SEK & 192.976 SEK \\
Beskattning (inkl jobbskatteavdrag) & 543.850 SEK & 49.750 SEK \\
Avräkning för trygdeavgift & 167.578 SEK & 143.226 SEK \\
Total skatt & 167.578 SEK & 463.474 SEK \\
\hline Nettoinkomst & 439.122 SEK & 24.352 SEK \\
\hline Skillnaden mellan dagsläget och avräkning av socialförsäkringsavgiften & & \\
\end{tabular}




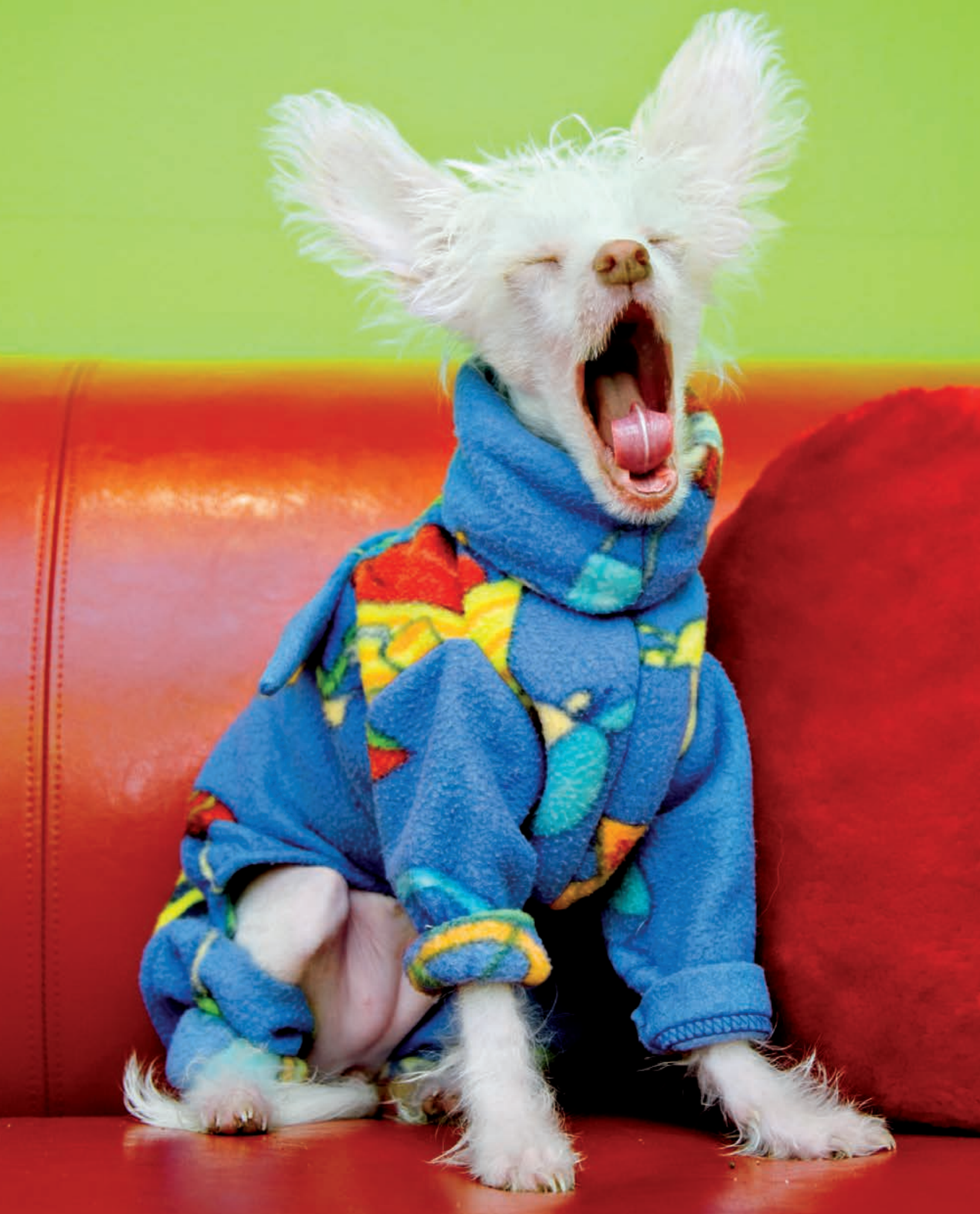




\title{
Problem med fast anställda kulturarbetare i Sverige
}

\author{
Kulturarbetare har en särreglering i det nordiska skatteavtalet. Artister \\ och sportutövare beskattas både i Danmark och Sverige när de arbetar \\ gränsöverskridande. Andra arbetstagare blir i princip endast beskattade \\ i arbetslandet om de inte har någon inkomst i bosättningslandet
}

Ett prioriterat gränshinder av Ole Stavad, Danmark samt MR-K.

Hindret kan lösas av det danska skatteministeriet och svenska finansdepartmentet.

\begin{abstract}
Bakgrund
I det Nordiska skatteavtalet specialregleras "artister och idrottsmän" i en särskild artikel. Specialregleringen innebär att artister och idrottsmän alltid beskattas i både Sverige och Danmark, med avräkning av den skatt som betalats i arbetslandet. Detta innebär att de ofta får betala en högre nominell skatt än andra löntagare i Öresundsregionen som i allmänhet endast betalar skatt i ett av länderna.
\end{abstract}

I Sverige finns så kallad "artistskatt" eller A-SINK för utomlands bosatta artister. A-SINK är en definitiv källskatt på 15 procent och inbetalas av arrangören/arbetsgivaren. Danmark har ingen motsvarande specifik artistskatt.

För Sveriges del innebär det exempelvis att vanliga löntagare som pendlar från Danmark till en fast anställning på den skånska sidan endast betalar SINK-skatt (20 procent fr.o.m. 2014) medan artister betalar A-SINK på 15 procent i Sverige men med kompletterande beskattning i Danmark på upp till 40 procent.

\section{Vem påverkas}

Gränshindret rör ca.100 fast eller tillfälligt anställda institutionsmusiker.

\section{Ekonomiska konsekvenser}

En symfoniker med en månadslön på SEK 30.000 skulle få en ökad årsinkomst på SEK 72.000 om hon/han skulle beskattas med vanlig SINK. Årsinkomsten efter skatt skulle då stiga från SEK 216.000 till SEK 288.000. Närmare beräkningar finns nedan.

\section{Förslag till lösning}

Ett förslag till lösning som Gränshinderrådet ser som tänkbart är att Sverige och Danmark inom ramen för det Nordiska skatteavtalet kommer överens om att art 17 inte ska tillämpas på artister med fasta anställningar. Det blir då istället med automatik beskattning enligt art 15 vilket innebär att metoden exempt blir tillämplig för Sveriges del.
Exempt, även kallad undantagsmetoden, innebär att inkomst helt eller till viss del undantas från beskattning i en stat oftast för att den beskattas i en annan stat. Det blir även exemptmetod för Danmark så länge den anställde är socialförsäkrad i Sverige. Den bästa tekniska lösningen får diskuteras fram, antingen en definition på fast anställning kopplat till kontrakt eller en generell tidsgräns på över sex månaders arbete för samma arbetsgivare.

En annan möjlighet som man ser från Gränshinderrådets sida är att fast anställda kulturarbetare i Sverige betalar vanlig SINK skatt istället för att betala A-SINK som turnerande musiker. Detta kommer att innebära att de inte kommer att mötas av krav på ytterligare beskattning i Danmark.

\section{Gränshinderrådets arbete med frågan \\ Under våren har Gränshinderrådet un- dersökt vilken status detta hinder har.}




\section{Beräkningar}

\section{Beskattning utifrån A-SINK (som det ser ut i dag)}

Årslön för symfoniker med SEK 30.000 månadslön

Svensk skatt $15 \%$

Dansk skatt $25 \%$

Nettolön per år

\section{Beskattning utifrån vanlig SINK (efter de föreslagna ändringarna)}

Årslön för symfoniker med SEK 30.000 månadslön

\section{Nuvarande status}

- Skatteministeriet i Danmark och Finansdepartementet i Sverige bör gemensamt undersöka om det finns någon lämplig lösning som innebär att en kulturarbetares inkomster kan undantas från beskattning i Danmark i fall där personen i fråga är socialförsäkrad i Sverige.

- Från dansk sida är man positiv till att hitta lösningar på de skattemässiga problem som upplevs av fastanställda kulturmedarbetare som bor i Danmark men har fast anställning i Sverige. Målsättningen är att fastaställda kulturarbetare skattemässigt skall behandlas på samma sätt som övriga fastanställda personer som bor i Danmark och arbetar i Sverige..

\section{Kommentarer från berörda regeringar}

Nedan finns även ett utdrag ur ett brev från det danska Skatteministeriet där det framgår att Danmark inte kommer att dubbelbeskatta fast anställda kulturarbetare om Sverige övergår till vanlig SINK:

"Vedrørende kulturarbejdere må vi fastholde det grundlæggende synspunkt, at alle erhvervsgrupper skal beskattes efter de samme regler, hvad enten der er tale om kulturarbejdere eller andre. Vi kan ikke gå ind i overvejelser om særordninger for enkelte erhvervsgrupper.

Som bekendt er kernen i problemstillingen, at Sverige beskatter kulturarbejder end en særlig lav skattesats (A-SINK), og kulturarbejdere derfor ikke kan få exemption i Danmark, selvom de er socialt forsikret i Sverige.

Hvis Sverige istedet beskatter kulturarbejdere med den almindelige SINKsats i stedet for den lavere A-SINK, vil de pågældende få exemption i Danmark, hvis de er socialt sikret i Sverige. Hvis de er socialt sikret i
Danmark, vil de få credit, men det gælder for alle.

Som du nævner i dit brev, beror en løsning på en ændring af de svenske regler. Der er for mig at se ikke behov for, at de danske regler ændres, da vi lægger afgørende vægt på, alle erhvervsgrupper beskattes efter samme regler.

Lad mig i denne forbindelse tilføje, at reglen om exemtionslempelse er en intern dansk regel og ikke en del af den nordiske skatteaftale. Baggrunden er, at der ved almindelig credit-lempelse ikke vil blive taget hensyn til de meget høje svenske socialsikringsbidrag."

Läs mer i gränshinderdatabasen, granshinder.norden.org, gränshinder nr:14-066. 


\title{
Beskattning av dansk kapitalpension
}

\author{
Danska kapitalpensioner påläggs en avgift vid utbetalningen. Avgiften omfattas \\ inte av det nordiska dubbelbeskattningsavtalet vilket medför en risk för dubbel- \\ beskattning om kapitalpensionen utbetalas i ett annat nordiskt land
}

Ett prioriterat gränshinder av Ole Stavad, Danmark.

Hindret finns med i det avtalet mellan det danska Folketinget och regeringen.

\begin{abstract}
Bakgrund
I Danmark tas det inte ut någon skatt på kapitalpensioner, istället betalar mottagaren en avgift i samband med utbetalningen. Om pensionen tas ut i t.ex. Norge anses den därför vara obeskattad vilket innebär att det norska skatteverket kan beskatta kapitalpensionen utan att beakta den avgift som redan betalats i Danmark. I praktiken blir konsekvensen en slags dubbelbeskattning av kapitalpensionen eftersom situationen inte täcks av det nordiska dubbelbeskattningsavtalet.
\end{abstract}

\section{Vem påverkas}

Problemet påverkar troligen ett mindre antal personer som rör sig över gränserna.

\section{Förslag till lösning}

Säkra så att endast ett land kan ta ut skatt/skatt på en kapitalpension.

T.ex genom ett avtal mellan berörda länder om att endast det land där kapitalpensionen uppsparats, har rätt att ta ut en avgift/skatt på kapitalpension.

Att man mellan länderna i detta fall likställer definitionen avgift med skatt.

\section{Gränsinderrådets arbete med frågan}

Under våren har Gränshinderrådet undersökt vilken status detta hinder har i Danmark.

- Hållit möte med den danska skatteministern den 26 maj som meddelade att det kommer att tas konkreta initiativ för att lösa gränshindret.

\section{Kommentarer från berörda regeringar}

Hvad angår Skatteministeriets to punkter på statuslisten - beskatning af uddannelsesstøtte og beskatning af kapitalpensioner - kan ministeriet til orientering oplyse, at der blandt de nordiske lande synes at være en positiv holdning over for en løsning af de pågældende spørgsmål. Det er dog samtidig indtrykket, at man ikke anser disse spørgsmål for at være af en sådan tyngde, at de i sig selv kan "bære" en protokol til ændring af den nordiske dobbeltbeskatningsoverenskomst. Dette hænger formentlig sammen med, at gennemførelse af en ændringsprotokol er en omstændelig procedure, der bl.a. involverer lovgivning.

Status er således, at de to spørgsmål medtages, når der bliver lejlighed til mere substantielle ændringer af den nordiske dobbeltbeskatningsoverenskomst.

Läs mer i gränshinderdatabasen, granshinder.norden.org, gränshinder nr: 14-154. 


\section{Hinder på näringslivsområdet}




\title{
Olika byggstandarder
}

\section{De nordiska ländernas krav på byggmaterial skiljer sig åt, vilket försvårar entreprenörernas verksamhet och hämmar handeln över gränser}

\author{
Ett gränshinder som prioriteras av Sten Palmgren, Finland, och Gunnar Westerholm, Åland. Även prioriterat av MR-NER. \\ Gränshindret ingår i avtalet mellan det danska Folketinget och regeringen.
}

Hela Norden berörs av detta hinder.

\begin{abstract}
Bakgrund
Olika byggregler och standarder gör det svårt för företag som är verksamma i ett land att röra sig över gränserna. Det har en negativ effekt på konkurrensen och gör det svårt att utveckla den nordiska gemensamma hemmamarknaden. Gränshindret är i sig mycket brett och består av en rad problemställningar som rör bl.a. VVS-området, elinstallationer, brand- och bullerskydd samt klassificering och certifiering av dessa.

En bidragande faktor är att många av standarderna sätts av ländernas branschorganisationer, något som gör det svårt att angripa problemet genom lagstiftning. I den mån det offentlig/ statlig reglering finns det i sin tur skillnader i de nivåer som standarderna sätts på. I Sverige finns regleringen t.ex. på lag-, förordnings- och myndighetsnivå medan den i Finland i huvudsak finns på förordningsnivå. Därutöver
\end{abstract}

finns olika rekommendationer, råd och frivilliga standarder med olika juridisk status beroende på vilket land det är fråga om. Rent konkret kan det röra sig om skillnader i kraven gällande t.ex. tröskelhöjder, bullerskyddsnivåer och virkesdimensioner.

Skillnaderna mellan länderna gör det förståeligt att det är svårt för mindre företag och småhusleverantörer att anpassa sin produktion till alla de olika kraven och standarderna. En del av problemen löses visserligen på europeisk nivå, men det finns stor potential för de nordiska länderna att fungera som föregångare och skapa gemensamma standarder. Det gäller i synnerhet utarbetandet av helt nya standarder och byggregler. Dessa kunde sedan tas vidare och implementeras på en europeisk nivå. En större grad av harmonisering skulle skapa en större marknad för alla entreprenörer i Norden och på sikt bidra till en lägre prisnivå för konsumenterna.

\section{Förslag till lösning}

Ett visst problemområde, t.ex. brandoch bullerskydd, görs till pilotprojekt för att utarbeta gemensamma nordiska standarder. Erfarenheterna kan sedan använda för att göra motsvarande övning gällande andra standarder.

\section{Gränshinderrådets arbete med frågan}

Diskussioner pågår i Finland med representanter för miljöministeriet och arbets- och näringsministeriet.

För att gå vidare med frågan borde fokus läggas på ett eller två konkreta hinder. Buller och brand är två pilotprojekt där det redan gjorts en del förarbete. Gränshinderrådets sekretariat utreder möjligheterna att ordna rundabordssamtal med relevanta parter. 


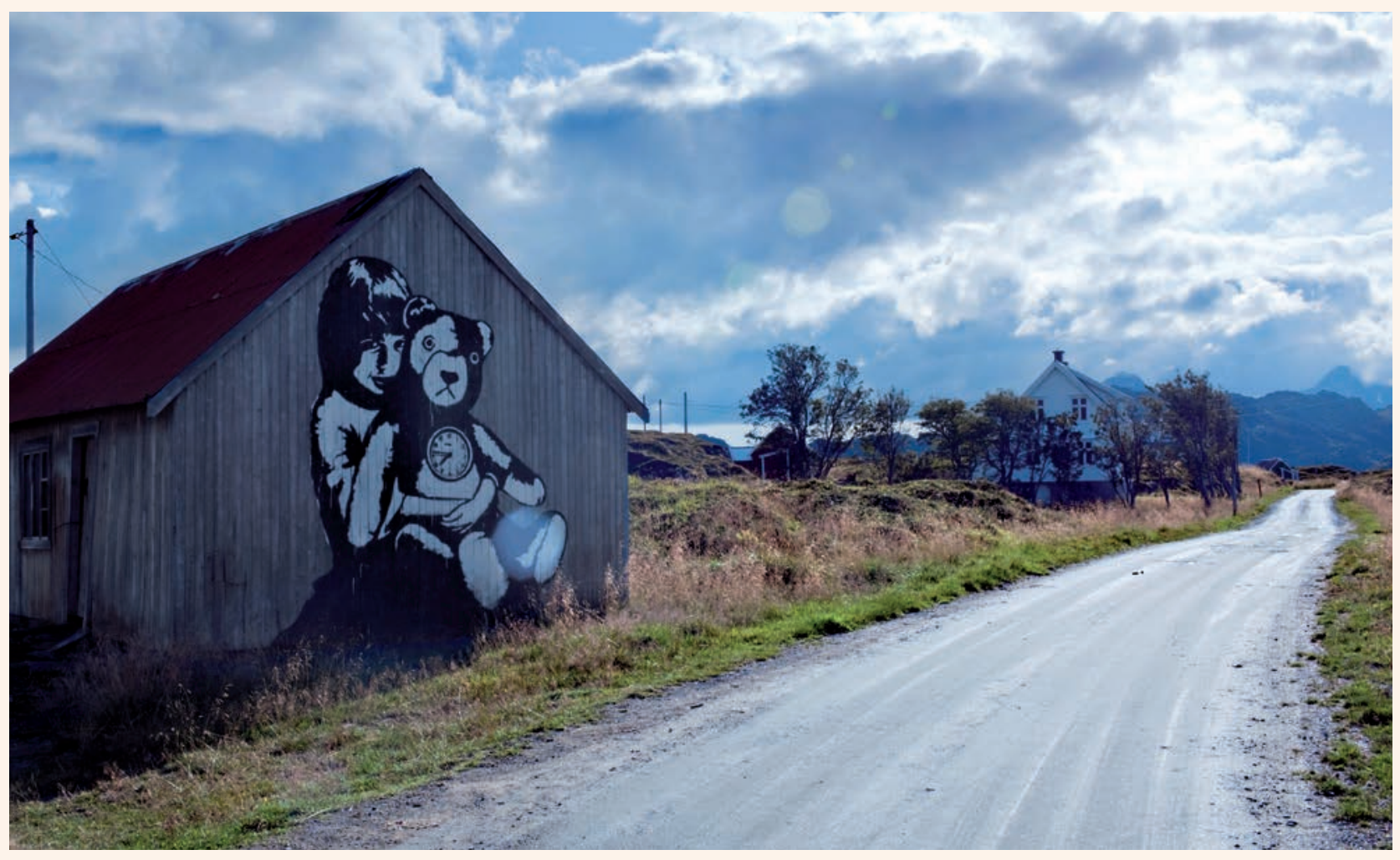

\section{Kommentarer från berörda regeringar}

Diskussioner har förts med miljöministeriet i Finland som betonar att man inte bör närma sig problematiken som en standardiseringsfråga utan som en fråga om byggnadstillsyn och nationella byggbestämmelser. Det nordiska informella samarbetet fungerar väl. Med hänsyn till de begränsade resurserna lönar sig nordiskt samarbete. Detta bör bedrivas inom Nordiska byggmyndigheternas möten, där man ska följa upp normgivningen, tillnärma normerna varandra och samarbeta i EU-frågor. De tjänstemän som kan påverka bör delta $\mathrm{i}$ Nordiska byggmyndigheternas möten.

\section{Arbetet bör fortsätta genom att}

- finna samarbetsformer och processer för att förmedla information om byggregler och för att utveckla dessa i olika länder med målet att tillnärma bestämmelserna varandra,

- beakta åtgärder på EU-nivå för byggprodukternas inre marknad och utveckla informationsförmedlingen i anslutning till EU:s lagstiftningsarbete och dess genomförande,

- utifrån gemensamma ståndpunkter förbereda föresatser till harmonisering av byggregler som har väsentlig inverkan för gränshinder med beaktande nationella kulturer för boende och byggande

Läs mer i gränshinderdatabasen, granshinder.norden.org, gränshinder $\mathrm{nr}: 14-076$. 


\section{Eltariffer för Åland}

\section{Åland importerar större delen av sin elektricitet från Sverige via kabel under Ålandshav. Kabeln ägs av Kraftnät Åland AB. Kabeln är ansluten till det svenska regionalnätet som i detta fall ägs av Vattenfall regionnät $A B$, vilket innebär att Åland måste betala eltariffer till Vattenfall}

Ett prioriterat gränshinder av Gunnar Westerholm, Åland. Även prioriterat av MR-NER.

Hindret kan lösas av Ålands landskapsregering, Sveriges regering (näringsdepartementet), Kraftnät Åland, Svenska kraftnät och Vattenfall $A B$.

\section{Bakgrund}

Eftersom Vattenfall regionnät $A B$ äger den $20 \mathrm{~km}$ luftledning som är ansluten till det statliga stamnätet i Sverige så betraktas Kraftnät Åland som en vanlig industrikund av Vattenfall, och inte som ett exportland. Åland har egen lagstiftningsbehörighet och en avreglerad elmarknad vilket borde klassificera Åland som exportland. Hade Kraftnät Åland varit anslutna direkt till svenska stamnätet hade så varit fallet.

Då Åland har egen lagstiftningsbehörighet över energifrågor ska Kraftnät Åland jämställas med det svenska stamnätsbolaget Svenska Kraftnät. Certifiering hos EU att Kraftnät Åland blir eget TSO, Transmission System Operator, väntas träda i kraft under hösten 2014. Enligt EU-direktivet 2009/72 och förordning $714 / 2009$ fastställs att avgifter mellan TSO inte ska förekomma.

\section{Vem påverkas}

Ålands ca. 29.000 invånare och ca 1.500 företag är starkast berörda, men vid årsskiftet 2015/2016 är en kabel mellan Åland och finska fastlandet klar för att tas i bruk. Det ger möjlighet för transferering mellan Finland och Sverige av bland annat grön el, vilket kommer förbrukare i Sverige, Åland och Finland till del.

\section{Ekonomiska konsekvenser}

År 2013 var den totala elförbrukningen på Åland 294 GWh. Ålands Kraftnät Ab importerade ca. $73 \%$, motsvarande till 214,9 GWh, från Vattenfall Eldistribution $A B$ i Sverige. Kraftnät Åland betalade år 2013 över 1,2 miljon Euro till Vattenfall i extra nätavgifter. När gränshindret blir löst bortfaller dessa nätavgifter, vilket medför en besparing på ca. 42€/år för en genomsnittlig förbrukare med en förbrukning på 10.500
KWh/år. Se närmare beräkningar nedan.

\section{Förslag till lösning}

Att Sveriges regering erkänner Kraftnät Ålands status som TSO och uppmanar Vattenfall att inleda samtal med Kraftnät Åland om nätavgifterna.

\section{Gränshinderrådets arbete med frågan}

Gränshinderrådet uppmanar till regeringssamtal mellan berörda ministrar. EU-reglerna på området har utretts. På Åland arbetar man nu för att få en TSO-certifiering (Transmission System Operator). Om certifieringen beviljas skulle gränshindret få en betydligt bättre chans att bli löst i praktiken, eftersom det framgår av direktiv och förordningar på området att fördyrande avgifter mellan TSO inte är förenliga med EU:s regler om en fri inre marknad. 


\section{Beräkningar}

\begin{tabular}{lrr} 
Elförbrukning 2013 & 294 GWh & $294000000 \mathrm{KWh}$ \\
Import från Vattenfall Eldistribution AB (Sverige) & 214,914 GWh & $214914000 \mathrm{KWh}$ \\
Kostnad för nätavgift till Vattenfall Eldistribution AB & $1200000 €$ & $1200000 €$ \\
\hline Nätavgift & $4081,6327 € / \mathrm{GWh}$ & $0,004081633 € / \mathrm{KWh}$ \\
\hline Genomsnittlig förbrukning hos åländska elförbrukare & $10500 \mathrm{KWh} / \mathrm{år}$ \\
\hline Om nätavgiften bortfaller sparar den genomsnittlige förbrukaren & $42,86 € /$ år
\end{tabular}

\section{Kommentarer från berörda regeringar}

Ålands energiminister: "För att få en effektiv och kostnadsbesparande nordisk elmarknad måste de av EU uppsatta regelverken, att extra kostnader för kraftöverföring mellan ländernas TSO (Transfer System Operators) inte tillåts, följas och att de till buds stående förbindelserna nyttjas på bästa sätt.”

\begin{abstract}
"Svenska Näringsdepartementet anser att det faktum att Sverige skulle erkänna Kraftnät Ålands status som TSO inte är en framkomlig väg för att hitta en lösning på frågan eftersom det inte har någon betydelse om Kraftnät Åland har status som TSO och regeringen bör inte försöka styra Vattenfall i denna fråga. Svenska regeringen anser även
\end{abstract}

att EU-direktivet 2009/72 och EU-förordningen 714/2009 inte är relevanta i sammanhanget."

Läs mer i Gränshinderdatabasen, granshinder.norden.org, gränshinder nr: 14-162 


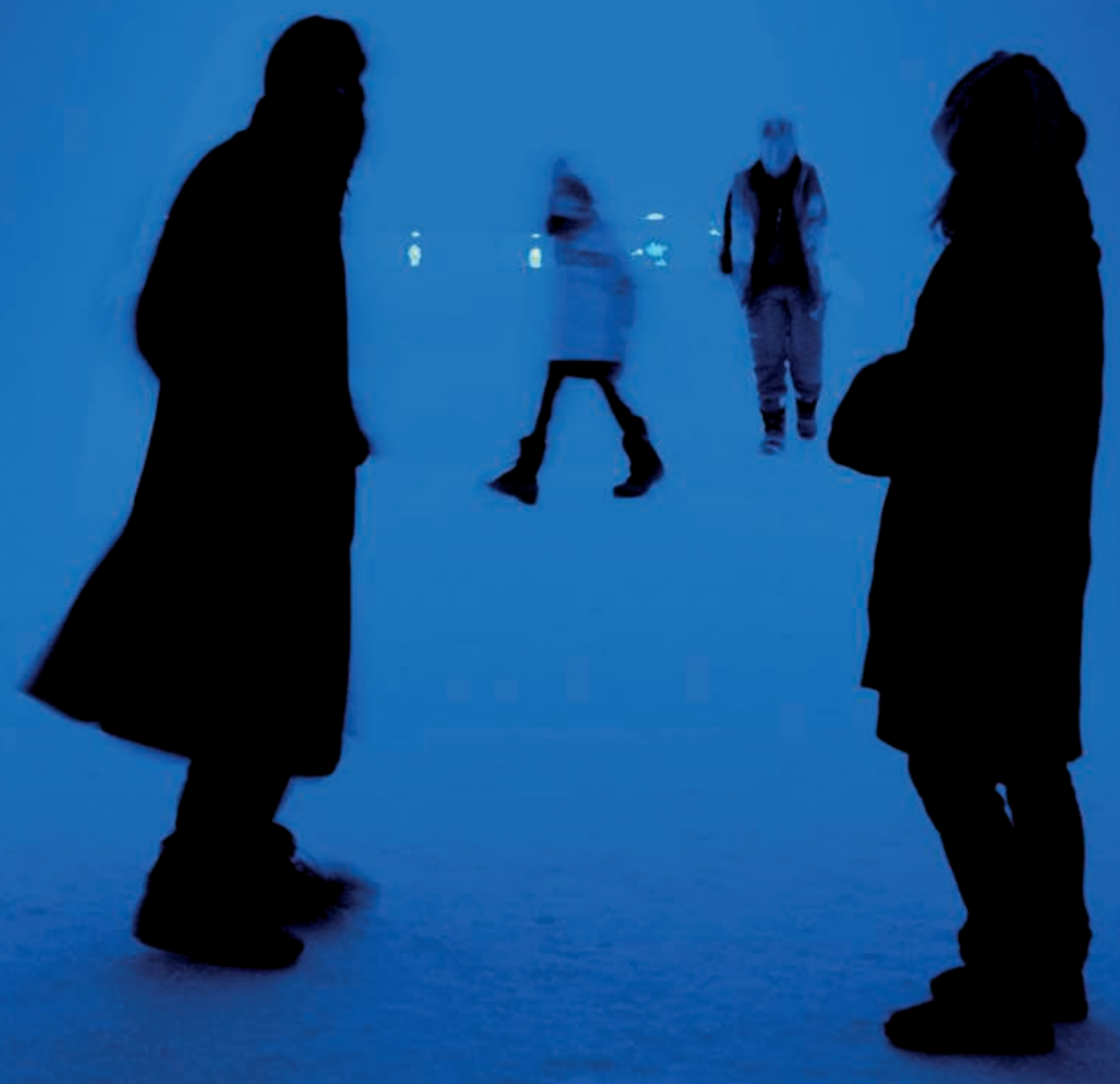




\title{
Erläggande av mervärdeskatt vid överförande av arbetsmaskin från Norge till Sverige
}

\author{
Ett norskt företag som ska införa en arbetsmaskin till Sverige för att där utföra \\ arbete, ska idag deponera mervärdesskatt till Sverige. Det betyder att den norske \\ företagaren har en konkurrensnackdel med tillfälligt ökade kostnader i form av \\ depositionen i förhållande till de svenska företagen samband med arbete i Sverige
}

Ett prioriterat gränshinder av Annika Hahn-Englund, Sverige samt av MR-Finans.

Hindret är löst av det svenska Finansdepartmentet.

\begin{abstract}
Bakgrund
Både EU och Norge är bundna av en internationell konvention som reglerar möjligheterna till tull/ momsfrihet (Istanbulkonventionen). Bestämmelserna är sålunda mycket svåra att ändra på.

Det betyder att den som för en anläggningsmaskin, exempelvis en grävmaskin, mellan Norge och EU ska betala mervärdesskatt för varan till Norge eller EU.

Kraven på betalning av mervärdesskatt vid införsel kan innebära likviditetsproblem för exempelvis små byggföretag som vill ta uppdrag på andra sidan gränsen.
\end{abstract}

\section{Vem påverkas}

Norska företag som vill in på den svenska marknaden.

\section{Förslag till lösning}

Skapa regler som underlättar för företagare som är registrerade till mervärdeskatt i Sverige att föra in arbetsmaskiner från Norge. Detta kan göras genom en förändrad hantering av mervärdeskatt vid import vilket bl.a. kommer att med underlätta för företagare som är registrerade till mervärdeskatt i Sverige att föra in arbetsmaskiner från Norge.

\section{Gränshinderrådets arbete med frågan}

Under våren har Gränshinderrådets svenska representant har under 2014 varit i kontakt med kontakt med Finansdepartementet i Sverige.

\section{Nuvarande status}

- Sveriges riksdag har i december 2013 antagit propositionen Förändrad hantering av mervärdeskatt vid import (2013/14:16) vilket bl.a. kommer att med underlätta för företagare som är registrerade till mervärdeskatt i Sverige att föra in arbetsmaskiner från Norge.

\section{Nästa steg}

- Under hösten kommer Gränshinderrådet att följa upp den vidare processen.

- Kontakt med Norge kommer också att tas gällande möjliga norska lagändringar

\section{Kommentarer från berörda regering}

Riksdagen har antagit en lag som innebär att gränshindret är löst för de företagare som väljer att registrera sig till medvärdesskatt i Sverige. Dessa förändringar träder i kraft den 1 januari 2015.

För att gränshindret ska bli helt löst krävs dock att även Norge ändrar sin lagstiftning, förhoppningen är att Norge kan vidta de nödvändiga ändringarna inom kort.

Läs mer i Gränshinderdatabasen, www.norden.org gränshinder nr: 14064. 


\title{
Norska tull- och momsregler för nordiska företag
}

\author{
Ett nordiskt företag som ska införa en arbetsmaskin till Norge för att utföra arbete \\ där ska idag deponera mervärdesskatt till Norge. Det betyder att den nordiska \\ företagaren har en konkurrensnackdel med tillfälligt ökade kostnader i form av \\ depositionen i förhållande till de norska företagen samband med arbete i Norge
}

Ett prioriterat gränshinder av Svein Ludvigsen, Norge samt av MR-Finans.

Hindret kan lösas av det norska finansdepartementet.

\section{Bakgrund}

Både EU och Norge är bundna av en internationell konvention som reglerar möjligheterna till tull/ momsfrihet (Istanbulkonventionen). Bestämmelserna är sålunda mycket svåra att ändra på.

Det betyder att den som för en anläggningsmaskin, exempelvis en grävmaskin, mellan Norge och EU ska betala mervärdesskatt för varan till Norge eller EU.

Kraven på betalning av mervärdesskatt vid införsel kan innebära likviditetsproblem för exempelvis små byggföretag som vill ta uppdrag på andra sidan gränsen.

\section{Vem påverkas}

Detta hinder påverkar företag från Danmark, Finland, Grönland, Färöarna, Norge, Sverige, Island och Åland som ska utföra entreprenadarbeten i Norge.

\section{Förslag till lösning}

En lösning som har diskuterats är att anpassa när och hur moms ska betalas (reverse charge), så att företagens likviditetsproblem minimeras. För att en sådan lösning ska kunna utvecklas krävs troligen politiska signaler till myndigheterna.

En annan möjlighet är att följa den svenska modellen.

\section{Ekonomiska konsekvenser}

Ett svenskt småföretag med en arbetsmaskin till ett värde av SEK 2,5 miljoner förväntas få en kostnad på SEK 530.000 Norge i samband med ett tremånadersarbete i Norge. Det är tre olika typer av kostnader som företaget har: räntekostnader till lån för att finansiera momsinbetalningen, avskrivning av arbetsmaskinens värde under arbetet i Norge samt en avgift på $5 \%$ av arbetsmaskinens värde för var månad arbetsmaskinen uppehåller sig i Norge.

Den norska staten får en intäkt på SEK 516.000 om det svenska företaget väljer att utföra uppdraget i Norge.
Närmare beräkningar finns nedan.

\section{Gränshinderrådets arbete med frågan}

Hindret har tagits upp via brev till det norska finansdepartementet men det har inte kommit något svar. Gränshinderrådets medlem har varit i kontakt med näringsorgansationer i Norge (Næringslivets hovedorganisation och Maskinentreprenörenes Landsforbund) under september-oktober 2014. I december 2014 har Gränshinderrådets norske medlem följa upp detta ärende med den norska samarbetsministern och berört departement, se svar från norska Finansdepartementet nedan. Gränshindret kommer även att lyftas till Nordiska rådets norska delegation 3 februari 2015.

\section{Kommentarer från berörda regeringar}

Norska Finansdepartementet meddelar att: Det vises til omtalen hvor innførsel av anleggsmaskiner mv. beskrives som et grensehinder på grunn av den 


\section{Beräkningar}

För en småföretagare med en omsättning på SEK 2 miljoner motsvarar en deposition en tredjedel av företagets årliga omsättning. Ett likviditetsbehov som småföretagaren inte kan uppfylla utan att ta lån. Vilket innebär att småföretagaren måste uppta ett lån med säkerhet i grävmaskinen till en ränta på 6 procent.

Arbetsmaskinens värde, Caterpillar 320DFMHW (årsmodell 2013)

2.500.000 SEK

Likviditetsbehov

650.000 SEK

\section{Utgifter för företagaren}

Räntekostnader vid lån till 6 procents ränta i ett halvt år

18.800 SEK

Avgift (5 \% av maskinens värde per månad i 3 månader)

375.000 SEK

Avskrivning av maskinens värde under perioden i Norge

136.000 SEK

Utgifter totalt

529.800 SEK

Intäkter för den norska staten

Ränteintäkter av en sex månaders deposition

4.700 SEK

Avgift (5 \% av maskinens värde per månad i tre månader)

Avskrivning av maskinens värde under perioden i Norge

Intäkter totalt

Pris på Caterpillar 320DFMHW (årsmodell 2013) hämtat på www.marcus.se

likviditetsbelastningen som oppstår som følge av innførselsmerverdiavgiften. Som et løsningsforslag skisseres regelverksendringer som innebærer utsatt avgiftsplikt.

I Sverige er det vedtatt å endre regelverket for innførselsmerverdiavgift fra 1. januar 2015. Lovendringene innebærer innførsel-merverdi-avgiften skal innberettes i samme termin som fradraget for inngående merverdiavgift kan kreves. Næringsdrivende med fradragsrett vil dermed ikke foreta noen reell innbetaling av innførsels`merverdi_avgiften.

I Norge er det igangsatt et omfattende prosjekt for å forbedre skatte- og avgiftsforvaltningen. Formålet med prosjektet er å rendyrke oppgavene til Skatteetaten og Toll- og avgiftsetaten. Som en del av dette prosjektet blir det utredet å flytte ansvaret for innførselsmerverdiavgiften fra Toll- og avgiftsetaten til Skatteetaten. I denne utredningen vil det bli vurdert om det skal innføres regler om utsatt avregning også i Norge. Det tas sikte på at overføringen av ansvaret for innførselsavgiften skal skje fra 1. januar 2016. Før dette må eventuelle forslag til regelverksendringer sendes på alminnelig høring.

Läs mer i Gränshinderdatabasen, granshinder.norden.org, gränshinder nr: 14-064. 


\title{
Färöiska färdskrivarkort
}

\author{
Färöiska yrkeschaufförer upplever problem med att få utställt digitala \\ färdskrivarkort på Färöarna (tachografer). Chauffören kan därför inte \\ registrera sin körtid i enlighet med de regler som gäller i Danmark och \\ de övriga nordiska länderna
}

Ett prioriterat gränshinder av Marjun Magnussen, Färöarna.

Hindret kan lösas vid samarbete mellan Danmark och Färöarna.

\section{Bakgrund}

Det så kallade AETR-avtalet (European Agreement concerning the Work of Crews of Vehicles Engaged in International Road Transport) innehåller regler om internationell yrkestrafik. Enligt avtalet ska yrkeschaufförer registrera sin körtid med en digital färdskrivare.

För parter som inte skrivit under avtalet, bl.a. Färöarna, finns dock en möjlighet att fortsättningsvis använda färdskrivarkort som fylls i för hand.

Nya fordon är dock i regel endast utrustade med en digital färdskrivare, vilket innebär att chauffören måste få tillgång till ett digitalt färdskrivarkort. Nuvarande EU-lagstiftning innehåller ett krav på bosättning, medan den förordning som antogs 2014, ger befrielse från detta krav. Denna förordning kommer inte att träda i kraft förrän 2016. Det finns på Färöarna ingen myndighet som kan utställa sådana digitala färdskrivarkort.

Det innebär i sin tur att en färöisk yrkeschaufför stöter på problem då hon/han kommer över till Danmark, eller något av de andra nordiska länderna, eftersom bristen på ett digitalt färdskrivarkort gör att det inte är möjligt att registrera körtiden enligt gällande regler.

\section{Vem påverkas}

Färöiska chaufförer, både de som kör i yrkesmässig trafik t.ex större bussar och transporter, och de som kör akuttransporter/nödhjälp.

\section{Förslag till lösning}

- Färöarna ansluter sig till AETR-avtalen, om det är möjligt

- Möjligheten öppnas för att utfärda digitala färdskrivare
- Färöarna utser en myndighet som kan utställa digitala färdskrivarkort

\section{Gränshinderrådets arbete med} frågan

Nuvarande status

- Frågan har diskuterats med danska Justitsministeriet, Rigspolitiet och Trafikstyrelsen. Från dansk sida har påvisats att det inte skulle uppstå problem med äldre fordon som inte har digitala färdskrivare. Det rör sig t.ex. om bussar med inregistreringsdatum den 1 maj 2006 eller tidigare.

- För nödhjälpstransporter utan kommersiella syften, kan transporten ske, förutsatt att det finns en transportbekräftelse från mottagarlandet. Det rekommenderas dock att transportören är försedd med bevis på att transporten är en akuttransport, och att också den som utför akut transport har en bekräftelse på 


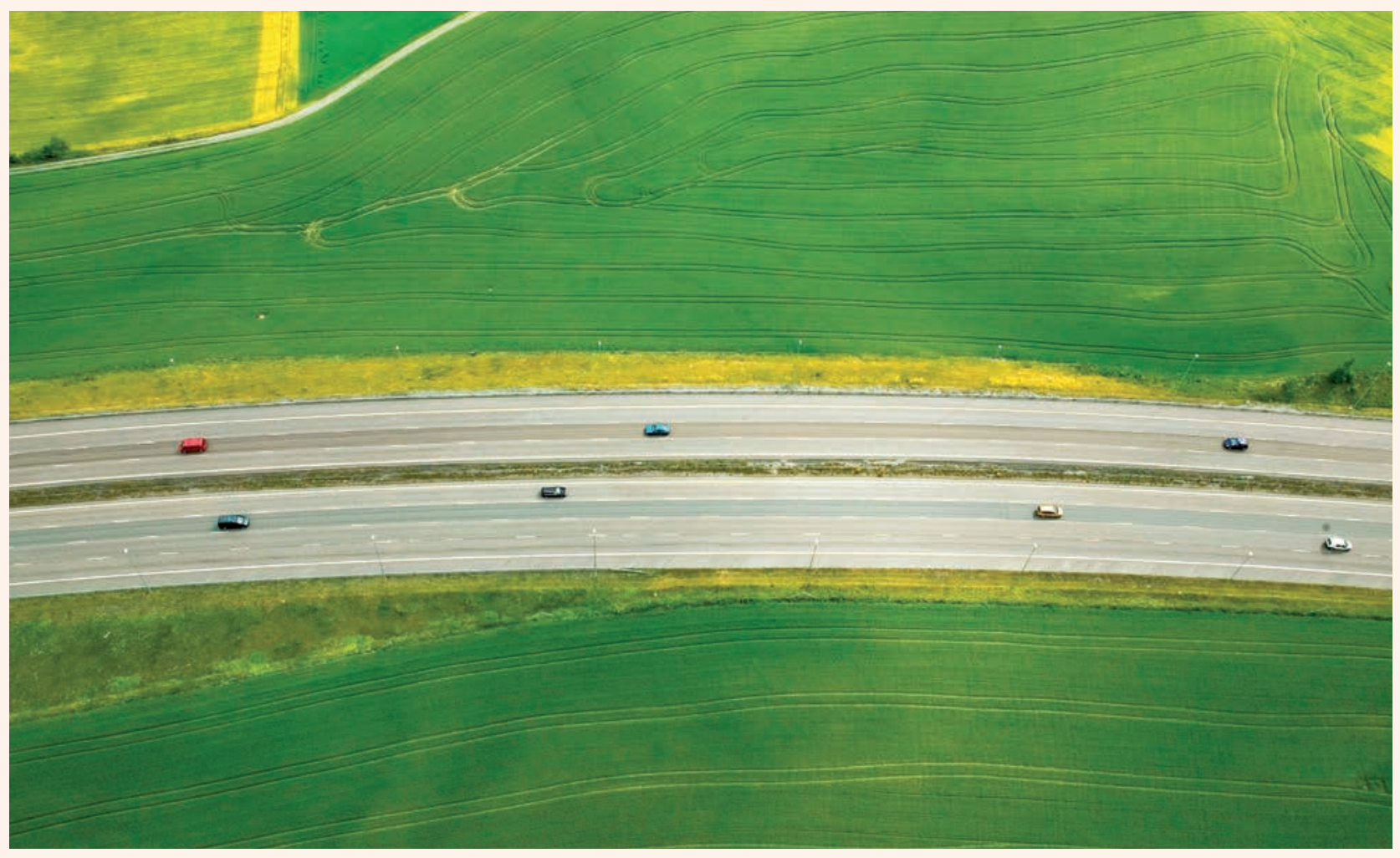

transportens riktighet i mottagarlandet.

- För yrkesmässig trafik är frågan är fortfarande olöst. I detta avseende hänvisas till de datum som den nya förordningen ger. Ministeriet för handel och industri (Vinnumálarádid) fortsätter att driva frågan, för att hitta en pragmatisk lösning. Det övervägs om ärendet ska tas upp mellan den färöiske lagmannen och den danske statsministern.

\section{Kommentarer från berörda regering}

Vinnumálarádið arbejder målrettet ad forskellige veje, at få etableret en rigtig kontakt, hvor sagens kerne kan diskuteres og hvor der vil blive forsøgt at finde en pragmatisk løsning.

I dette arbejde søges samarbejde hos flere myndigheder, henholdsvis hos Justitsministeriet, Trafikstyrelsen, Færøernes udsendte i Danmark og Statsministeriet. Det er tvingende nødvendigt, at der findes en løsning senest den 1. apríl 2015, hvor sæsonen for at gennemføre charterrejser fra Færøerne til Danmark og andre destinationer, begynder. Vinnumálarádid var ikke i indeværende år i stand til at etablere en løsning for de mange busser i charterrejse-øjemed, og dette er en uholdbar situation for erhvervslivet.

Läs mer i gränshinderdatabasen, granshinder.norden.org, gränshinder nr: 14-152. 


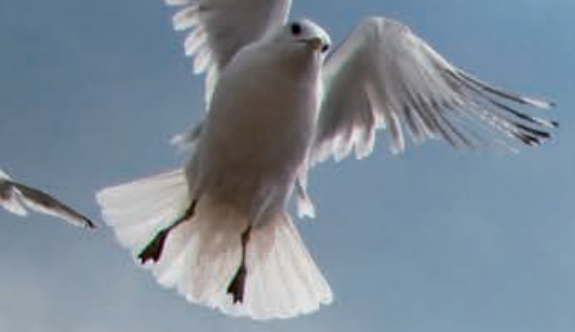

tow ty
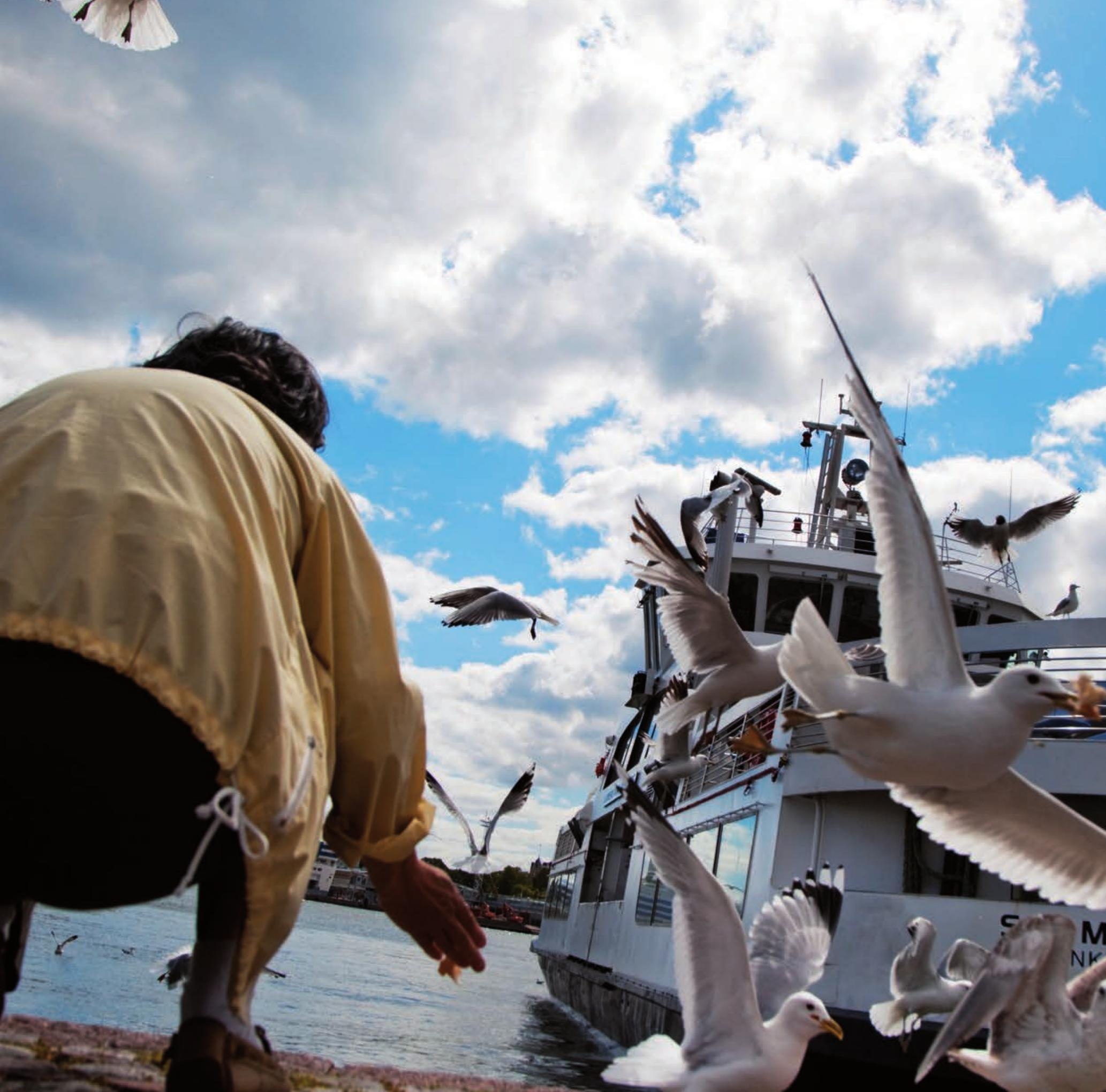


\title{
Samordningsnummer till utländska fritidshusägare i Sverige
}

\author{
Utländska fritidshusägare i Sverige upplever problem med att teckna el-, \\ tele- och internetavtal på grund av att de varken har personnummer eller \\ samordningsnummer
}

Ett prioriterat gränshinder av Annika Hahn-Englund, Sverige.

Hindret kan lösas av det svenska Finansdepartmentet (dock ej helt då samordningsnummer inte ersätter personnummer i alla avseenden).

\begin{abstract}
Bakgrund
Även om problemet rör en begränsad grupp av människor så visar detta ändå tydligt vilka konsekvenser avsaknaden av ett personnummer har. Det gäller i synnerhet i Sverige där systemen för service, tjänster och handel är uppbyggt på personnummer.

För betalning av fastighetsavgift m.m. får utländska fritidshusägare ett så kalllat GD-nummer som de använder i kontakt med Skatteverket. Detta nummer har ingen spridning i samhället i övrigt. Numret fyller i stort sett ingen funktion i kontakt med privata aktörer, vilket leder till problem vid tecknandet av t.ex. el-, tele- och internetavtal. Utländska fritidshusägare har därför behov av att få ett så kallat samordningsnummer, som får spridning i samhället genom Statens personadressregister, SPAR.
\end{abstract}

\section{Vem påverkas}

Utländska fritidshusägare i Sverige, totalt ca. 36.500 personer varav ca. 22.500 kommer från Danmark, Norge eller Finland. Av dessa har 78\%, ca. 28.700 personer, uppgett att de har behov av ett samordningsnummer.

\section{Ekonomiska konsekvenser}

Enligt en utredning gjord av svenska Skatteverket kostar det SEK 19 miljoner, en engångsinvestering, att införa ett system där Lantmäteriet ges möjlighet att tilldela utländska fastighetsägare ett samordningsnummer. Det årliga sparandet enligt samma utredning värderas till SEK 870.000 vilket betyder att denna investering kommer att vara intjänad inom 25-28 år.

Om hälften av de utländska fritidshusägarna som uppgett att de har behov av ett samordningsnummer skulle teckna ett TV-abonnemang till SEK 269/månad, skulle de bidra öka omsättningen för TV-abonnemang med ca. SEK 46 miljoner. Närmare beräkningar finns nedan.

\section{Förslag till lösning}

Samordningsnummer ska även tilldelas utländska fritidshusägare.

\section{Gränshinderrådets arbete med frågan \\ Under våren har Gränshinderrådets svenska representant varit i kontakt med Finansdepartementet i Sverige.}

\section{Nuvarande status}

- Skatteverket har nyligen, på uppdrag av Finansdepartementet, utrett frågan och dragit slutsatsen att det är möjligt att tilldela utländska fritidshusägare ett samordningsnummer, och att kostnaden för Skatteverket förväntas vara SEK 19 miljoner. 


\section{Beräkningar}

Antal utländska fritidshusägare i Sverigre

36.761 personer

Norrmän

11.605 personer

Finländare

235 personer

Danskar

11.605 personer

Övriga

13.316 personer

Andel som är i behov av samordningsnummer $=78 \%$

28.674 personer

Hälften av dessa tecknar ett TV-avtal (beräknat för Boxer Mix)

14.337 personer

Kostnad för TV-avtal/månad

269 SEK

Total årlig utgift för utländska fritidshusägare, enbart för TV-avtal

46.279.158 SEK

Kostnad för att införa samordningsnummer

19.000.000 SEK

Nästa steg

- Under hösten kommer gränshinderrådet att följa upp den vidare processen.

\section{Kommentarer från berörda regeringar}

Frågan ligger nu hos Finansdepartementet, som i november 2014 skickat ut Skatteverkets promemoria på remiss för synpunkter senast den 6 februari 2015.
Läs mer i Gränshinderdatabasen, granshinder.norden.org, gränshinder nr: 14-160. 


\section{Erkännande av färöiska körkort}

\section{Färöiska körkort kan inte bytas ut i alla de nordiska länder då en person flyttar till ett annat nordiskt land}

Ett prioriterat gränshinder av Marjun Magnussen, Färöarna.

\section{Bakgrund}

När en person bosätter sig i ett nordiskt land ska gällande körkort bytas ut till bosättningslandets.

Färöiska körkort kan inte bytas ut i alla nordiska länder. I Sverige och i Finland betraktas det färöiska körkortet som utgivet $\mathrm{i}$ ett land som inte är medlem av EU och kan därför inte bytas ut mot det svenska eller det finska.

Färöarna omfattas inte av överenskommelsen gjord den 12 november 1985 mellan Danmark, Finland, Sverige och Norge om gemensamt godkännande av körkort och registrering av fordon och det är inte möjligt att ansluta till överenskommelsen vid nuvarande tidpunkt. Det har funnits överväganden om att göra en revision av överenskommelsen i nordisk regi, men detta har lämnats utan åtgärd, då de områden som överenskommelsen omfattar, till stor del regleras av EU-regler, inklusive EU:s körkortsregler. Färöarna är varken medlem av EU eller EES.
Det är möjligt att byta ut det färöiska körkortet mot ett danskt, norskt, isländskt och brittiskt. Detta kan innebära att innehavaren av ett färöiskt körkort tvingas mellanemigrera till ett av dessa länder, för att kunna byta ut sina körkort vid bosättning i Sverige eller Finland.

Det finns inga trafiksäkerhetsmässiga aspekter att beakta vid utbyte av körkort. Färöarna har till stor del implementerat körkortsdirektivet i färöisk lagstiftning. Under hösten har den färöiska lagen som berör körkort, åter uppdaterats i förhållande till körkortsdirektivet och den förväntas således inom kort att tas i användning
Under hösten har den färöiska lagen gällande körkort åter uppdaterats i relation till körkortsdirektivet. Inom kort förväntas ett färöiskt körkort att bli identiskt med andra körkort inom EU/EES och uppfylla alla EU/EES-krav/ regler.

\section{Förslag till lösning}

De länder som idag inte har behörighet att ersätta det färöiska körkortet skulle kunna se över gällande regler för en bedömning av möjligheten att byta körkort på samma villkor som för medborgare i övriga Norden och i EU/EES-länderna.

\section{Vem påverkas}

Personer med färöiska körkort kommer att påverkas. Det är svårt att säga hur många, då det antas att en del av dessa i dag väljer att mellanemigrera. Oavsett hur många personer det rör sig om är det viktigt för enskilda personer som drabbas.

De flesta personer bör kunna byta ut det färöiska körkortet mot ett nytt som uppfyller EU:s krav/regler, precis som med tidigare färöiska pass, vilka kunde bytas ut mot EU-pass.

\section{Gränshinderrådets arbete med frågan \\ Gränshinderrådet har under våren undersökt vilken möjligheten är att få detta hinder löst.}




\section{Nuvarande status}

- Det är möjligt att byta in ett färöiskt körkort i Island, Norge, Danmark och Storbritannien. Sverige, Finland och Åland godkänner dock inte färöiska körkort. I Finland och på Åland har man begränsad erfarenhet av frågan, men på motsvareande sätt som Sverige så går det troligtvis inte att byta in ett färöiskt körkort till ett finskt/ åländskt körkort. Om det nya färöiska körkortet uppfyller EU-krav/regler, kan det verka ogrundat, att det färöiska körkortet inte kan bytas till ett svenskt körkort.

- Frågan togs upp under den svenska samarbetsministerns besök på Färöarna i maj.

- Sveriges gränshindersrepresentant lyfte möjligheten för Färöarna att lösa gränshindret genom ändringar $\mathrm{i}$ sin egen lagstiftning, t.ex. genom att likställa färöiska körkort med danska körkort. Detta förslag avvisas av Färöarna, då detta sakområde är en färöisk fråga. Dessutom godkänns både färöiska och danska körkort $\mathrm{i}$ Danmark och på Färöarna.

\section{Kommentarer från berörda regeringar}

Färöiska Vinnumálarádið meddelar att: Indledningsvis skal Vinnumálarádið gøre opmærksom på, at Vinnumálarádid og Akstovan málrettet vil gå efter, at Færøerne bliver omfattet af overenskomsten af 12. november 1985 mellem Danmark, Island, Finland, Sverige og Norge om gensidig anerkendelse af kørekort og registrering af køretøjer, uanset om det bliver fremhævet, at det ikke er muligt på nuværende tidspunkt at tiltræde.

\section{Det er især i forhold til Sverige og} Finland, at hindringen opstår. Mere enkelt og pragmatisk kan fremhæves, at Færøerne kan ombytte kørekort hvad angår Danmark. Færøerne er en del af Rigsfællesskabet, hvorfor det falder naturligt, at ombytning kan finde sted.

UK har aftalerelateret samarbejde med Akstovan, som ajourføres til efteråret med det engelske BVL.
Derudover kan færøske kørekort ombyttes til islandske og norske kørekort uden hindringer.

Vinnumálarádið overvejer, for at formalisere reelle bilaterale aftaler med de lande, hvor ombytning kan finde sted, at påbegynde forhandlinger med disse lande. Det er især med Sverige, hvor man ønsker en hurtig afklaring, idet der er efterspørgsel fra færinger af en vis størrelse om ombytning.

I tillæg til besøg fra den svenske samarbejdsministeren her på Færøerne i mai 2014, vil Vinnumálarádið overveje, at henvende sig til vedkommende ministerium, med henblik på at at skabe grobund for, at der bør findes en pragmatisk løsning også med Sverige, når henses til, at de andre nordiske lande kan ombytte kørekort med Færøerne.

Läs mer i gränshinderdatabasen, granshinder.norden.org, gränshinder nr:14-128. 


\section{Grönländska körkort}

Ett prioriterat gränshinder av Christian Wennecke, Grönland.

Hindret kan lösas av Rigspolitiet.

\section{Bakgrund}

Den som reser till Danmark med sitt grönländska körkort, kan använda det i 90 dagar, därefter måste personen göra ett körprov. Detta körprov kan anses vara irrelevant om personen redan har kört i 90 dagar.

Olika regler gäller för körkort från respektive Färöarna och Grönland $i$ de nordiska länderna. De regler som gäller för Grönland är ofta strängare än de regler som gäller för Färöarna. Du kan använda det färöiska körkortet i Danmark utan att behöva byta ut kortet, eller betala för körprov.

\section{Vem påverkas?}

Ett svar förväntas från Rigspolitiet om hur många grönländska körkort som bytts ut det senaste året, samt hur stor misslyckandeprocenten är för körprovet i detta sammanhang.

\section{Ekonomiska konsekvenser}

Den som berörs av detta hinder har

följande utgifter:

- 280 DKK för utbyte av körkort

- 890 DKK för körprov

- Hyra av godkänt fordon till körprovet

- Eventuella extra körtimmar

\section{Förslag till lösning}

a) Undersök om Grönland och Färöarna får ansluta sig till relevant EU-lagstiftning, och därmed lösa problemet i förhållande till alla de länder som inte nämner Grönland och Färöarna specifikt i sin lagstiftning.

b) Länder som särskilt nämner Grönland i sin lagstiftning (exempelvis Norge), kan behöva ändra sin lagstiftning.

\section{Gränshinderrådets arbete med frågan}

Gränshinderrådet diskuterade det färöiska körkortet i maj 2014.

\section{Kommentarer från relevanta regeringar}

Der forventes at blive bedt om svar fra Justitsministeriet i Danmark.

Läs mer i gränshinderdatabasen, granshinder.norden.org, gränshinder nr. 14-172. 


\section{(3)}

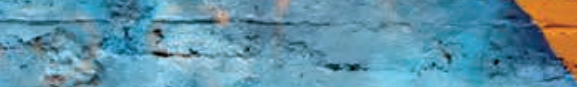

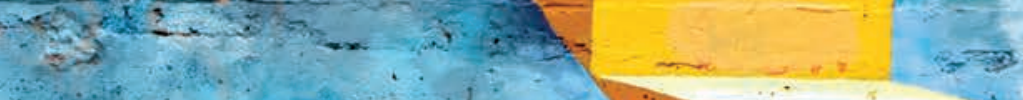

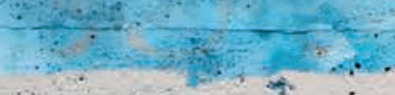

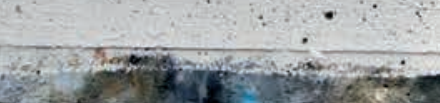

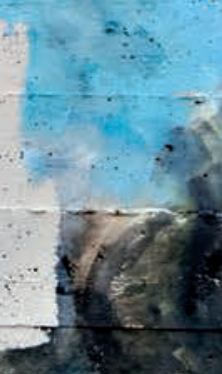
it 


\title{
Akuta gränshinder
}

\author{
Utöver prioriterade gränshinder driver Gränshinderrådet även de gränshin- \\ der som uppkommer och identifieras som akuta, och som är av särskilt stort \\ intresse att få lösta under året. Denna typ av gränshinder uppkommer oftast \\ genom ändringar i regelverken
}

\section{Arjeplogavtalet}

Under sommaren 2014 har processen omkring det så kallade Arjeplogavtalet drivits som ett akut gränshinder av Gränshinderrådet. Arjeplogavtalet, eller "Överenskommelse om gemensam nordisk arbetsmarknad för viss hälsooch sjukvårdspersonal och veterinärer", ingicks 1993 och trädde i kraft den 1 januari 1994. Överenskommelsens syfte är att ge nordiska medborgare inom de av avtalet berörda 22 yrkesgrupperna tillgång till hela den nordiska arbetsmarknaden. Exempelvis ska en person som har en godkänd fysioterapeututbildning i Finland också få sin utbildning godkänd och kunna arbeta som fysioterapeut i Sverige.

Ett upphävande av överenskommelsen har utretts i S-sektorn sedan 2011. De bakomliggande orsakerna till diskussionen om ett upphävande är bl.a. att det finns en betydande överlappning mellan Arjeplogavtalet och EU:s yrkeskvalifikationsdirektiv 2005/36/EG samt patientsäkerhets-aspekter.
Frågan om ett upphävande fanns på dagordningen för ett planerat MR-S möte i Reykjavik i juni 2014 men eftersom mötet inställdes så tillfrågades länderna om deras inställning till att saken behandlas i skriftlig procedur. Den inställningen godtogs av Danmark, Finland, Norge och Sverige men inte av Island.

I samband med det inställda mötet bad Gränshinderrådet i brev av 27 juni 2014 de nordiska social- och hälsovårdsministrarna skjuta fram processen och vänta med vidarebehandlingen av ärendet för att ge Gränshinderrådet möjlighet att diskutera vilka konsekvenser ett möjligt upphävande av Arjeplogavtalet har på gränshinder mellan de nordiska länderna. I brev av 7 juli 2014 blev Gränshinderrådet informerad av den isländska hälsoministeren, Kristján Júlíusson, och den isländska ministern för miljö och naturresurser, Sigurður Ingi Jóhannsson, att ärendet behandlas på MR-S möte den 16 oktober 2014.
Gränshinderrådet beslöt på sitt möte den 2 september 2014 att utforma ett uttalande till MR-S där Gränshinderrådet bad MR-S beakta möjligheten att finna alternativa lösningar till förslaget att upphäva Arjeplogavtalet. Uttalandet, daterat den 23 september 2014 , föreslog som ett alternativ att överenskommelsen revideras för att anpassas till de nuvarande förhållandena, speciellt den utveckling som skett i andra regelverk på europeisk och nationell nivå.

MR-S behandlade Arjeplogavtalet på sitt möte i Köpenhamn den 16 oktober 2014. MR-S enades om, att före det tas ett beslut om upphävande så ska ÄK-S ge ett förslag på hur man säkrar informationsutbytet mellan länderna (artikel 18) och hur man tillvaratar de speciella behoven för Färöarna, Grönland och Åland. ÄK-S ska framlägga sitt förslag till MR-S i god tid före årsskiftet 2015/2016. 
2011-2014

Diskussion om

upphävande i ÄK-S
16.10.2014

MR-S möte och

upphävande framskjuts

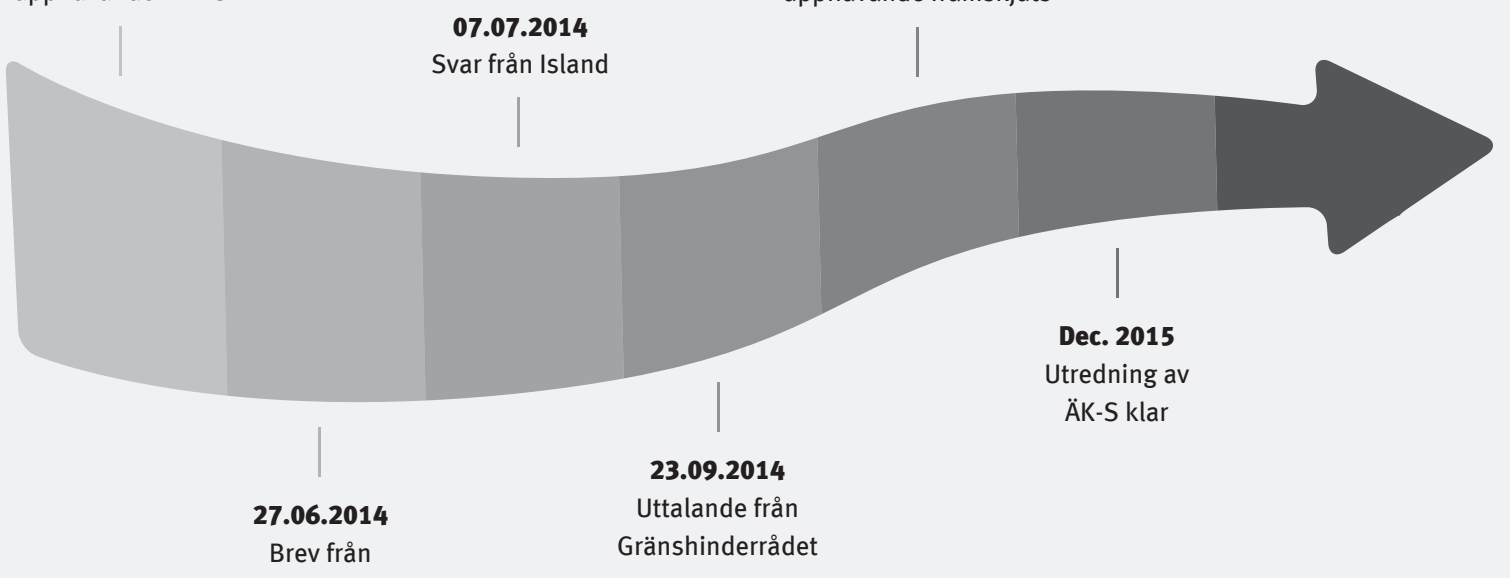

Gränshinderrådet

\section{Språkkrav för danska yrkesutbildningar}

I det danska reformarbetet av danska yrkesutbildningarna fanns ett förslag kring införande av nya intagningskrav vilket var att de ansökande skulle ha, som behörighetskrav, minst betyg 02 i danska och matematik. Detta förslag skulle ha gått mot den Nordiska Språkkonventionen som jämställer de skandinaviska språken.
Informationstjänsten Øresunddirekt uppmärksammade detta problem för den danske medlemmen i Gränshinderrådet, Ole Stavad, den 26 februari. Stavad kontaktade Folketingsmedlem Ane Halsboe-Jørgensen som i sin tur lyfte frågan i ett brev till Undervisningsministeriet.

Undervisningsminister Christine Antorini svarade i ett brev daterat den 5 mars 2014 att den danska utbildningsreformen inte kommer att exkludera norska och svenska ungdomar som söker till danska yrkesutbildningar. Deras språkkunskaper kommer också fortsättningsvis att godkännas och uppfylla de danska kraven förutsatt att de nått en godkänd nivå i sitt hemland. Därmed kunde detta hinder lösas förrän det uppstått. 


\section{Informationsarbetet}

Gränshinderrådet har utöver organiseringen och implementeringen av det systematiska gränshinderarbetet, lett av ordföranden i Gränshinderrådet, även tagit initiativ till att utveckla och implementera en gemensam handlingsplan för den nordiska informationstjänsten Hallo Norden och de gränsregionala informationstjänsterna, Grensetjänsten, Øresunddirekt och Nordkalottens gränstjänst. Syftet med handlingsplanen är att effektivisera och understödja Gränshinderrådets arbete samt förbättra informationsinsatserna för privatpersoner och företag som vill röra sig över de nordiska nationsgränserna.

\section{Det förebyggande arbetet}

Under 2014 har Gränshinderrådet tagit initiativ till att utveckla en strategi för hur de nordiska länderna samt Färöarna, Grönland och Åland ska bidra till att förebygga uppkomsten av nya gränshinder vid införandet av ny lagstiftning och implementeringen av EU-direktiv. Strategin kommer att implementeras från om med januari 2015.

Under hösten ska Gränshinderrådet även inleda ett arbete med att gå igenom de anvisningar som används under lagberedningen. Målet är att se i vilken omfattning likheter och olikheter i de övriga nordiska ländernas lagar beaktas under lagstiftningsarbetet.

På Färöarna har gränshinderfrågor redan fått ett större fokus under lagberedningen. I nya lagförslag finns numera ett särskilt avsnitt som behandlar lagförslagets effekt på rörligheten i Norden. 


\section{Efterord}

\author{
VAESST, VELF/ERD OG VAERDIER er over- \\ skriften for det danske formandskab $i$ \\ 2015. Arbejdet i Grænsehindringsrådet \\ skal være med til at virkeliggøre den \\ målsætning.
}

Der er fortsat barrierer, som står i vejen for at virkeliggøre det fulde potentiale i et nordisk samarbejde. Norden er vort største marked. Vi arbejder, handler, flytter og driver virksomhed på tvær af Nordens grænser.

Vi er forskellige lande, så der vil altid være en forskellighed, som kan føles besværligt. Men, uhensigtsmæssige regler, unødigt bureaukrati og mangelfuld information, skal rettes og bekæmpes. Det må ikke stå i vejen for vækst og beskæftigelse. Det skal være trygt for de mange tusinde nordboere, der flytter og arbejder på tværs af Nordens grænser.

\section{2015 vil Grænsehindringsrådet fortsætte og drive videre med den visionære dagsorden, som blev sat af det islandske formandskab. Vi vil fastholde fokus på arbejdstagernes og de enkelte menneskers frie bevæge- lighed over grænserne, uden at miste rettigheder eller opleve unødvendige problemer.}

Herudover vil vi supplere med et endnu stærkere fokus på de problemer, som vore virksomheder oplever, når de opererer på tvær af de nordiske lande. Her er et potentiale for yderligere vækst og beskæftigelse. Minister for nordisk samarbejde Carsten Hansen har nedsat en arbejdsgruppe med repræsentanter fra erhvervslivet og lønmodtagerne, som vil rådgive om de områder og de problemer, hvor der er størst behov og størst gevinst ved gøre en indsat med at bekæmpe grænsehindringer.

Den vigtigste opgave er fortsat at forhindre nye problemer og nye barrierer $\mathrm{i}$ at opstå. Det lyder enkelt, men i praksis kræver det en massiv indsats og en tæt kontakt mellem myndighederne i vore lande. Hver gang et land ændrer praksis, regler og lovgivning, skal der tages høje for, de nye regler ikke skaber problemer og nye barrierer for "Nordens Indre Marked" og den frie bevægelighed. Også samarbejdet om udarbejdelse og implementering af EU direktiver, er et fokusområde, hvor vi hele tiden arbejder for at koordinere og gøre det bedre.

En anden stor opgave er, at sikre præcis og forståelig information, som er let tilgængelige. Det arbejdes der hele tiden med at forbedre. Lige så vigtigt er det, at disse informationer når ud til de virksomheder og personer, der har brug for dem. Ved at opbygge et kontaktnet med alle relevante organisationer, der har store medlemsskarer, kan vi sikre informationerne er lette at finde, når man skal bruge dem.

Det er fortsat en hovedopgave for Grænsehindringsrådet at drive på for at fjerne og nedbryde eksisterende hindringer. Det er et besværligt og langsommeligt arbejde, men gennem de seneste år har Norden alligevel leveret meget betydelige resultater, som gør det stadig enklere for mennesker og virksomheder at bevæge sig på tværs af grænserne i Norden. Det tætte samarbejde med parlamentarikerne i Nordisk Råd har en stor betydning for at nå disse vigtige fremskridt.

Jeg ser frem til i 2015 at fortsætte samarbejdet med gode kolleger fra alle de nordiske lande og selvstyrende områder. Norden har fortsat et stort potentiale for udvikling.

Ole Stavad, ordførende i Grænsehindringsrådet 2015 


\section{nordan}

Nordiska ministerrådet

Ved Stranden 18

DK-1061 København K

www.norden.org

ANP 2015:703

ISBN 978-92-893-3919-3 (PRINT)

ISBN 978-92-893-3920-9 (PDF)

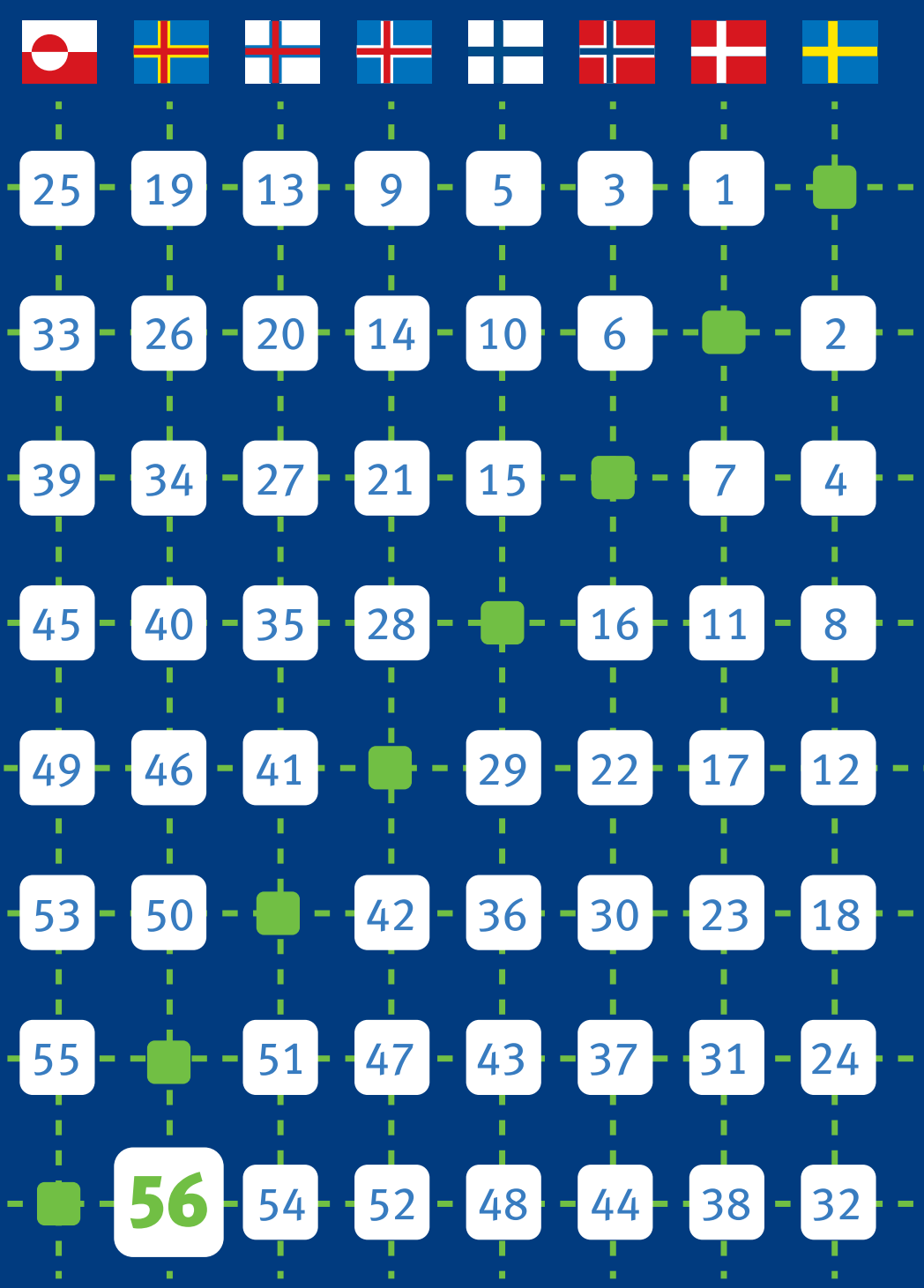

